


\section{USER GUIDE FOR PROCUREMENT OF WORKS: SMALL CONTRACTS STANDARD BIDDING DOCUMENT}

DECEMBER 2021 


\section{(c) $\$($ Creative Commons Attribution-NonCommercial-NoDerivs 3.0 IGO license BY NC ND (CC BY-NC-ND 3.0 IGO)}

(C) 2021 Asian Development Bank

6 ADB Avenue, Mandaluyong City, 1550 Metro Manila, Philippines

Tel +6328632 4444; Fax +63286362444

www.adb.org

Some rights reserved. Published in 2021.

ISBN 978-92-9269-294-0 (print); 978-92-9269-295-7 (electronic)

Publication Stock No. TIM210537-2

DOI: http://dx.doi.org/10.22617/TIM210537-2

The views expressed in this publication are those of the authors and do not necessarily reflect the views and policies of the Asian Development Bank (ADB) or its Board of Governors or the governments they represent.

ADB does not guarantee the accuracy of the data included in this publication and accepts no responsibility for any consequence of their use. The mention of specific companies or products of manufacturers does not imply that they are endorsed or recommended by ADB in preference to others of a similar nature that are not mentioned.

By making any designation of or reference to a particular territory or geographic area, or by using the term "country" in this document, $A D B$ does not intend to make any judgments as to the legal or other status of any territory or area.

This work is available under the Creative Commons Attribution-NonCommercial-NoDerivs 3.0 IGO license (CC BY-NC-ND 3.0 IGO) http://creativecommons.org/licenses/by-nc-nd/3.0/igo/. By using the content of this publication, you agree to be bound by the terms of this license. For attribution and permissions, please read the provisions and terms of use at https://www.adb.org/terms-use\#openaccess.

This CC license does not apply to non-ADB copyright materials in this publication. If the material is attributed to another source, please contact the copyright owner or publisher of that source for permission to reproduce it. ADB cannot be held liable for any claims that arise as a result of your use of the material.

Please contact pubsmarketing@adb.org if you have questions or comments with respect to content, or if you wish to obtain copyright permission for your intended use that does not fall within these terms, or for permission to use the ADB logo.

Corrigenda to ADB publications may be found at http://www.adb.org/publications/corrigenda.

Note:

In this document, "\$” refers to United States dollars.

This document applies to projects governed by the Procurement Regulations for ADB Borrowers:

Goods, Works, Nonconsulting and Consulting Services (2017, as amended from time to time). 


\section{Contents}

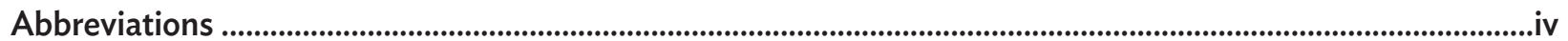

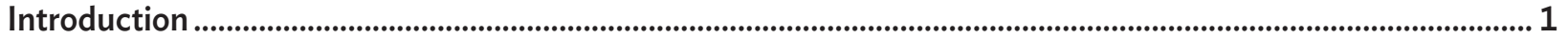

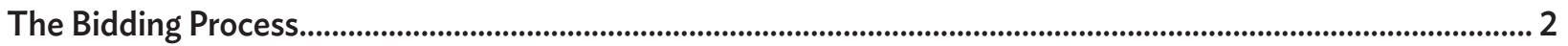

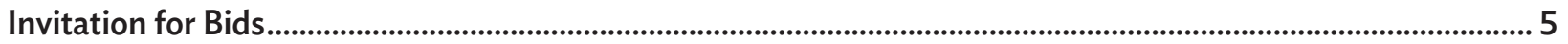

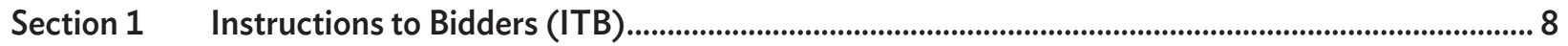

This section specifies the procedures Bidders should follow when preparing and submitting their Bids.

Information is also provided on the submission, opening, evaluation of bids, and on the award of contract.

Section 2 Bid Data Sheet (BDS)

This section consists of provisions that are specific to each procurement, and supplement the information or requirements included in Section 1 (Instructions to Bidders).

Section 3 Evaluation and Qualification Criteria (EQC).

This section contains the criteria to determine the lowest evaluated bid and the qualifications of the Bidder to perform the contract if the bidding were not preceded by a prequalification exercise.

Section 4 Bidding Forms (BDF)

This section contains the forms to be completed by the Bidder and submitted as part of its Bid if the bidding were not preceded by a prequalification exercise.

Section 5 Eligible Countries (ELC)

This section contains the list of eligible countries.

Section 6 Employer's Requirements (ERQ)

This section contains the Specifications, Drawings, Supplementary Information that describe the Works to be procured, Personnel Requirements, and Equipment Requirements.

Section 7 General Conditions of Contract (GCC)

This section contains the general clauses to be applied in all contracts. These Conditions are subject to the variations and additions set out in Section 8 (Particular Conditions of Contract).

Section 8 Particular Conditions of Contract (PCC).

This section contains provisions that are specific to each contract and that modify or supplement the General

Conditions of Contract. Whenever there is a conflict, the provisions herein shall prevail over those in the

General Conditions of Contract.

Section 9 Contract Forms (COF).

This section contains forms that, once completed, will form part of the Contract. The forms for Performance

Security and Advance Payment Security, when required, shall only be completed by the successful Bidder after contract award. 


\title{
Abbreviations
}

\author{
ADB........................ Asian Development Bank \\ BDF ........................ Bidding Forms \\ BDS ....................... Bid Data Sheet \\ COF........................ Contract Forms \\ CON ....................... Historical Contract Nonperformance \\ ELC ......................... Eligible Countries \\ ELI ............................ Eligibility Form \\ EQC ......................... Evaluation and Qualification Criteria \\ EQU ........................ Equipment Form \\ ERQ .......................... Employer's Requirements \\ EXP ......................... Experience Form \\ FIN ........................... Financial Data Form \\ GCC ….................. General Conditions of Contract \\ IFB............................ Invitation for Bids \\ ITB ............................ Instructions to Bidders \\ OCB ...................... Open Competitive Bidding \\ PCC ....................... Particular Conditions of Contract \\ PER …….................. Personnel Form \\ SBD ........................ Standard Bidding Document
}




\section{Introduction}

The Standard Bidding Document for the Procurement of Works-Small Contracts (SBD Works-Small) has been prepared by the Asian Development Bank (ADB) for use in contracts involving "smaller" contracts-valued at generally less than $\$ 10$ million by open competitive bidding. It is based on the Master Document for Procurement of Small Works, prepared by multilateral development banks and international financing institutions. It reflects the structure and the provisions of the Master Document, except where specific considerations within ADB have required a change.

The SBD Works-Small follows a postqualification procedure that requires Bidders to submit the information pertaining to their qualification together with their bids. In this event, it will be necessary to ensure that a Bidder's risk of having its bid rejected on grounds of qualification is remote if due diligence is exercised by the Bidder during bid preparation. For that purpose, clear-cut, pass-fail qualification criteria need to be specified by the Employer in both the Invitation for Bids as well as the Bidding Document to enable Bidders to make an informed decision on whether to pursue a specific contract and, either to do so as a single entity or in Joint Venture. Postqualification criteria, requirements, and relevant forms for submission are covered in Section 3 (Evaluation and Qualification Criteria) and Section 4 (Bidding Forms).

The SBD Works-Small is intended for both lump sum (activity schedule) and admeasurement (unit prices in a bill of quantities) types of contract, which are the most common in civil works contracting. Lump sum contracts are used particularly for building construction and other forms of construction where the works are well defined and are unlikely to change in quantity or specification, and where it is unlikely to encounter difficult or unforeseen site conditions (for example, hidden foundation problems). Otherwise, admeasurement contracts should be used.

The main text is applicable to both types of contracts (lump sum and admeasurement). Fixed prices are provided as a default, unless price adjustment is allowed and indicated in Section 2 (Bid Data Sheet).

An important feature of the SBD Works-Small, which is only available in electronic format on the ADB website, is that it can be used with minimum changes, as it does not contain explanations, footnotes, or examples that should not form part of the Bidding Document. The provisions in Section 1 (Instructions to Bidders) and Section 7 (General Conditions of Contract) must be used with their text unchanged.

This user's guide is provided to guide employers in preparing a bidding document based on the SBD Works-Small for single-stage: one-envelope bidding procedure. This guide includes the Bidding Process and the Invitation for Bids, which are not part of the Bidding Document.

ADB welcomes any feedback or experiences from both Borrowers and Bidders on the use of its Standard Bidding Document. For information on procurement under ADB-financed projects, contact

Procurement, Portfolio and Financial Management Department (PPFD)

Asian Development Bank

6 ADB Avenue, Mandaluyong City

1550 Metro Manila, Philippines

E-mail: procurement@adb.org

Tel: +63286324444

Fax: +63286362444 [Attn: Director General, PPFD]

www.adb.org 


\section{The Bidding Process}

The open competitive bidding (OCB) process includes six main phases: (i) advertisement and notification, (ii) preparing and issuing the Bidding Document, (iii) bid preparation and submission, (iv) bid opening, (v) bid evaluation, and (vi) contract award.

\section{Advertisement and Notification}

Following OCB procedure, Invitation for Bids (IFB) shall be advertised on the Asian Development Bank (ADB) website; on a freely and publicly accessible website in English; and in a newspaper of national circulation (at least in one English language newspaper, if available) or website in the Borrower's country. However, when foreign Bidders are unlikely to participate and as agreed with ADB in the Procurement Plan, the IFB may be advertised in a newspaper of national circulation or official gazette or a free and publicly accessible website in the Borrower's country. A copy of the IFB shall be submitted to ADB for no-objection when the contract is subject to prior review and for publication on the ADB website when it is required in accordance with the Procurement Regulations for ADB Borrowers: Goods, Works, Nonconsulting and Consulting Services (2017, as amended from time to time).

\section{Preparing and Issuing a Bidding Document}

The Employer is responsible for preparing and issuing the Bidding Document for a specific contract.

The Bidding Document shall be prepared by the Employer based on the appropriate Standard Bidding Document (SBD) issued or agreed by $A D B$, as this is a mandatory requirement for contracts to be financed by $A D B$. The following $A D B$-issued SBDs are published on the ADB website:

- SBD Works (Small Contracts) Single-Stage: One Envelope, and

- SBD Works (Small Contracts) Single-Stage: Two Envelope.

The Employer shall prepare the Bidding Document using the published version of the SBD without suppressing or adding text to the sections of the document that must be used without modification, which are Section 1 (Instructions to Bidders) and Section 7 (General Conditions of Contract). All information and data particular to each individual bidding process must be provided by the Employer in the following sections of the Bidding Document:

- Section 2 (Bid Data Sheet)

- Section 3 (Evaluation and Qualification Criteria)

- Section 4 (Bidding Forms)

- Section 5 (Eligible Countries)

- Section 6 (Employer's Requirements)

- Section 8 (Particular Conditions of Contract)

- Section 9 (Contract Forms) 
The following directions should be observed by the Employer when finalizing the Bidding Document:

- In preparing the Bidding Document, the Employer should refer to this User Guide for Procurement of Works: Small Contracts as it contains guidance and instructions for the Employer.

- Specific details, such as name of the Employer, address for bid submissions, qualification requirements, electronic procurement procedures, etc. should be provided in the spaces indicated by italicized notes in bracket.

- The "italicized notes," giving guidance and instructions for the Employer, except those that apply to forms to be filled out by Bidders, should be deleted from the actual Bidding Document.

- Where alternative clauses or text are shown, the Employer shall select the most appropriate for the particular works and discard the unused clauses or text.

The Employer shall allow Bidders sufficient time (generally, not less than 4 weeks from the issuance or publication date of the Invitation for Bids or the date of availability of Bidding Documents, whichever is later) to study the Bidding Document, prepare complete and responsive Bids, and submit their Bids.

\section{Bid Preparation and Submission}

The Bidder is solely responsible for the preparation and submission of its Bid. During this stage, the Employer shall

- promptly respond to requests for clarifications from Bidders and amend the Bidding Document as needed, and

- amend the Bidding Document only with prior approval of ADB in case the contract is subject to prior review.

\section{Bid Opening}

The Employer is responsible for the Bid Opening, which is a critical event in the bidding process. The Employer shall appoint experienced staff to conduct the Bid Opening, as inappropriate procedures at Bid Opening are usually irreversible and may lead to cancellation of the bidding process with consequent delays and waste of resources.

The Employer, in observance of best practices, shall perform the following checks:

- Conduct the Bid Opening strictly following the procedures as specified in the Instructions to Bidders for all Bids received not later than the date and time of the bid submission deadline. The term "Bid Opening" should be understood in the context of the ITB because, as provided in the ITB, a Bid for which a Bid Withdrawal or Bid Substitution notice was received on time shall not be opened, but returned unopened to the Bidder. The sequence in which Bids are handled, opened, and recorded is crucial.

- Ensure that all Bids that were received on time are accounted for, before starting the Bid Opening, as Bids that are not opened and read out at Bid Opening shall not be considered further.

- Not reject any Bid at Bid Opening, except for late bids received after the date and time of the bid submission deadline. Technically, late bids should not reach the Bid Opening, but in certain cases a Bidder may attempt to submit its bid at the Bid Opening place after the deadline. This late bid shall also not be considered.

- Examine the Bids at Bid Opening in accordance with the provisions of the Instructions to Bidders. The Employer shall, however, verify at Bid Opening the validity of the documentation such as Power of Attorney or other acceptable equivalent document as specified in the Instructions to Bidders. The validity of a bid modification, bid withdrawal, or bid substitution should be confirmed, because a withdrawn or substituted Bid shall not be opened or read out and, therefore, shall not be considered by the Employer. A valid bid modification shall be opened, read out, and recorded to modify a Bid that was received on time. 


\section{Bid Evaluation and Contract Award}

The Employer is responsible for bid evaluation and contract award. The Employer shall appoint experienced staff to conduct the evaluation of the Bids. Mistakes committed at bid evaluation may later prompt complaints from Bidders, requiring reevaluation of the Bids, with consequent delays and waste of resources.

The Employer, in observance of best practices, shall

- keep the bid evaluation process strictly confidential;

- reject any attempts or pressures to distort the outcome of the evaluation, including fraud and corruption; and

- strictly apply only and all of the evaluation and qualification criteria specified in the Bidding Document.

\section{Use of Electronic Procurement System}

When an electronic procurement system is used, the applicable procedures of the bidding process such as (i) advertisement and notification; (ii) preparing and issuing the Bidding Document; (iii) bid preparation and submission; (iv) bid opening; ( $v$ ) bid evaluation; and (vi) contract award, including the means of communication between the Employer and Bidders, shall be specified in the relevant clauses of Section 2 (Bid Data Sheet). 


\section{Invitation for Bids}

The Invitation for Bids (IFB) provides information that enables potential Bidders to decide whether to participate. Apart from the essential items listed in the SBD, the IFB should also indicate any important bid evaluation criteria, such as the application of domestic preference in bid evaluation, and qualification requirements, such as a requirement for a minimum level of experience in contracts of a similar size and nature for which the IFB is issued.

The IFB is not a part of the Bidding Document and therefore it shall not be included in the Bidding Document.

The IFB shall be advertised on the Asian Development Bank (ADB) website; on a freely and publicly accessible website in English; and in a newspaper of national circulation (at least in one English language newspaper, if available) or website in the Borrower's country. A copy of the IFB shall be submitted to ADB for no-objection when the contract is subject to prior review and for publication on the ADB website when it is required in accordance with the Procurement Regulations for ADB Borrowers: Goods, Works, Nonconsulting and Consulting Services (2017, as amended from time to time). However, when foreign Bidders are unlikely to participate and as agreed with ADB in the Procurement Plan, the IFB may be advertised in a newspaper of national circulation or official gazette or a free and publicly accessible website in the Borrower's country. 


\title{
Standard Format for Invitation for Bids
}

\author{
[Letterhead of the Employer]
}

\begin{abstract}
Date.
Loan/Grant No. and Title.

Contract No. and Title.

Deadline for Submission of Bids

[insert closing date and time]
\end{abstract}

1. The [insert name of the Borrower or recipient] has received ${ }^{1}$ financing from the Asian Development Bank (ADB) toward the cost of [insert name of the project]. Part of this financing will be used for payments under the Contract ${ }^{2}$ named above. Bidding is open to Bidders from eligible source countries of ADB. ${ }^{3}$

2. The [insert name of the Employer] ("the Employer") invites sealed bids from eligible Bidders ${ }^{3}$ for the construction and completion of [insert brief description of the Works and statement of the principal quantities involved ${ }^{4}$ ("the Works").

3. Open competitive bidding will be conducted in accordance with ADB's [insert appropriate bidding procedure ${ }^{5}$ procedure and is open to all Bidders from eligible countries as described in the Bidding Document. ${ }^{6}$

4. Only eligible Bidders with the following key qualifications ${ }^{7}$ sdefined in the Bidding Document may participate in this bidding:

[insert key experience requirement]

[insert key financial requirement]

5. To obtain further information and inspect the bidding documents, Bidders should contact:

[insert employer's office $]^{8}$

[insert name of the officer]

[insert postal address or street address, include zip code]

[insert telephone number including country code]

[insert e-mail address]

[insert fax number]

Substitute with "has applied for" if appropriate.

Substitute "contracts" where bids are called concurrently for multiple contracts. Add a new para. 2 and renumber paras. 2-8 as follows: "Bidders may bid for one or several contracts, as further defined in the bidding document. Bidders wishing to offer discounts in case they are awarded more than one contract will be allowed to do so, provided those discounts are included in the Letter of Bid."

$3 \quad$ Add if applicable: "This contract will be jointly financed by..... insert name of cofinancing agency..... The eligibility rules and procedures of ADB will govern the bidding process."

$4 \quad$ A brief description of the type(s) of works should be provided, including principal quantities, location of project, and other information necessary to enable potential bidders to decide whether to respond to the invitation.

5 Insert one of the bidding procedures adopted by ADB, which are (a) Single-Stage: One-Envelope, and (b) Single-Stage: Two-Envelope.

6 The list of eligible countries will be specified in Section 5 of the Bidding Document.

$7 \quad$ Insert an additional paragraph indicating key qualification criteria consistent with the bidding document to enable potential Bidders to decide whether to respond to the invitation.

8 The Borrower and the Employer may be the same or different entities. The text of the Invitation for Bids and the text of the other associated documents must indicate which agency will act as the Employer. 
6. To purchase the bidding documents in English, eligible Bidders should

- write to address above requesting the bidding documents for [insert number and title of the contract]

- pay a nonrefundable fee ${ }^{9}$ of [insert amount and currency] by [insert method of payment $]^{10}$.

7. Deliver your bid

- to the address [insert address];

- on or before the deadline: [insert closing date and time consistent with the Bidding Document]; and

- together with a Bid Security/Bid-Securing Declaration as described in the Bidding Document.

Bids will be opened promptly after the deadline for bid submission in the presence of Bidders' representatives who choose to attend.

8. When comparing Bids, Domestic Preference will be applied as stipulated in the Bidding Document. ${ }^{11}$

The fee chargeable should be only nominal to cover reproduction and mailing costs. For example, cashier's check, direct deposit to a specified account number, etc.

Include para. 8 only if Domestic Preference has been expressly provided in the Procurement Plan and is included in the Bid Data Sheet. 


\section{Section 1: Instructions to Bidders}

This section specifies the procedures to be followed by Bidders when preparing and submitting their Bids. Information is also provided on the submission, opening, evaluation of bids, and award of contract.

\section{Table of Clauses}

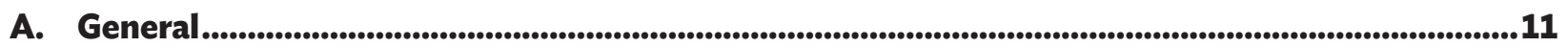

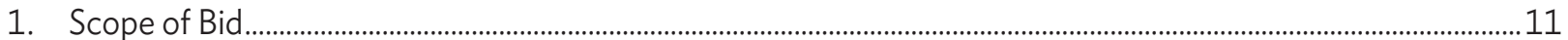

2. Source of Funds

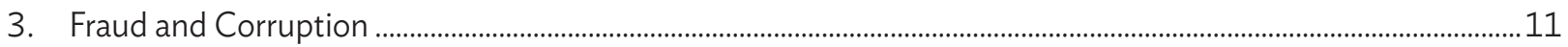

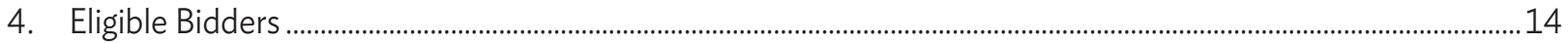

5. Eligible Materials, Equipment, and Services ……………………………………………………………………......

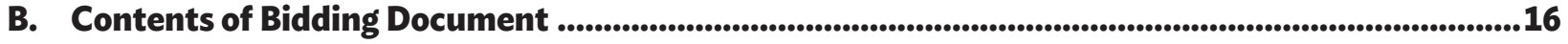

6. Sections of Bidding Document ................................................................................................................................................... 16

7. Clarification of Bidding Document, Site Visit, Pre-Bid Meeting ..............................................................................17

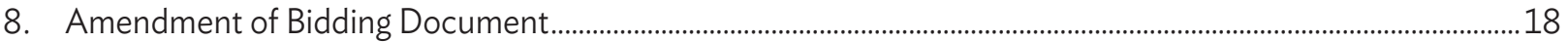

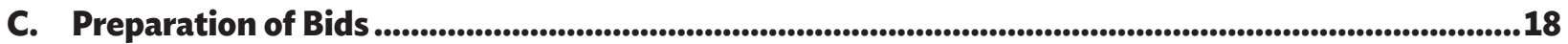

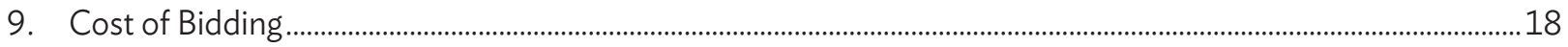

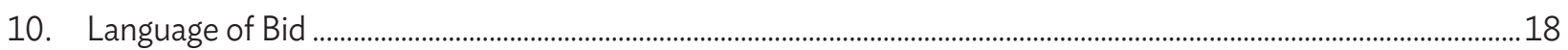

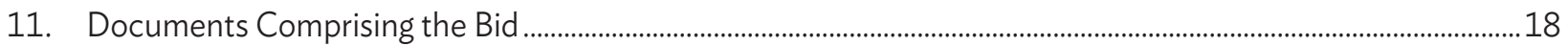

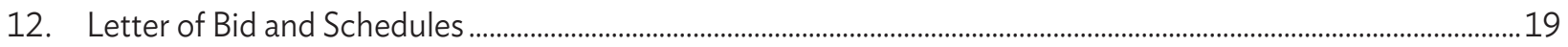

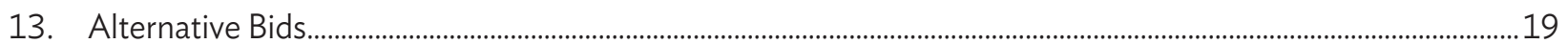

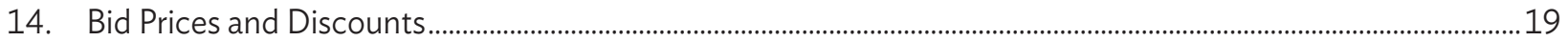

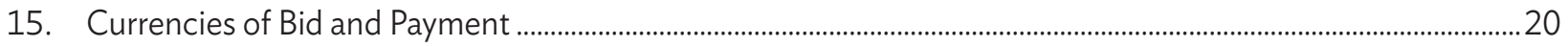

16. Documents Comprising the Technical Proposal.......................................................................................................20

17. Documents Establishing the Qualifications of the Bidder ..........................................................................................2 
18. Period of Validity of Bids ..........................................................................................................................................................2

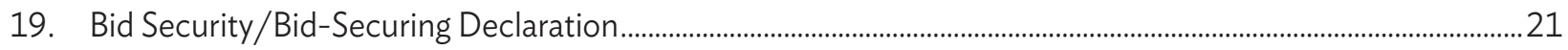

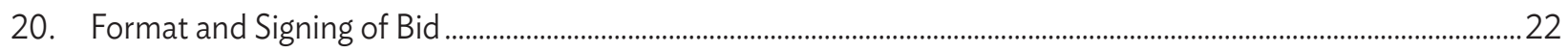

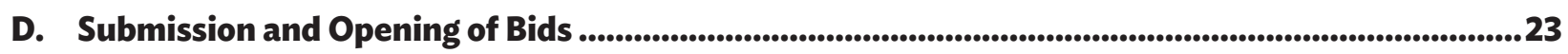

21. Sealing and Marking of Bids ................................................................................................................................................23

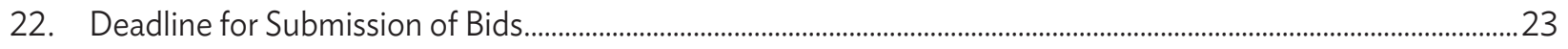

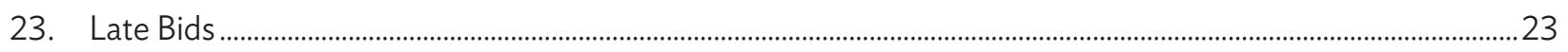

24. Withdrawal, Substitution, and Modification of Bids .................................................................................................24

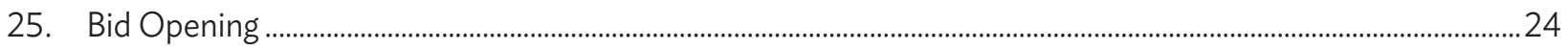

E. Evaluation and Comparison of Bids ..................................................................................................................25

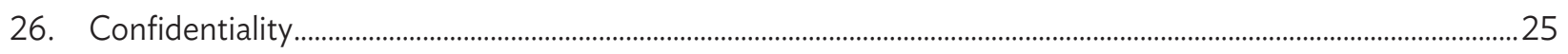

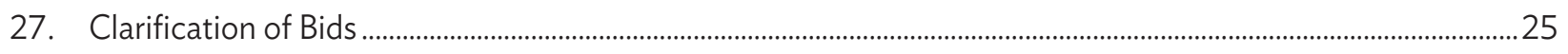

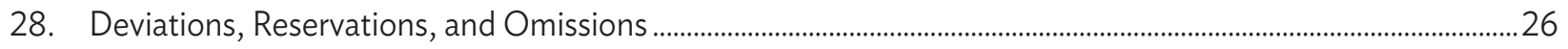

29. Determination of Responsiveness.............................................................................................................................. 26

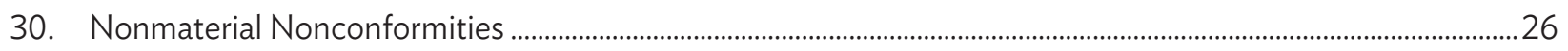

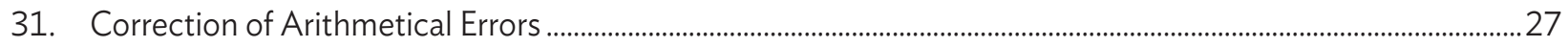

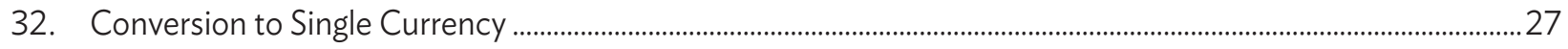

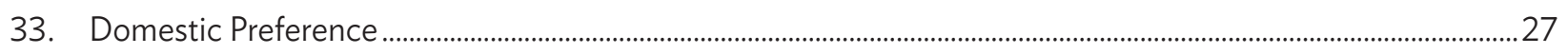

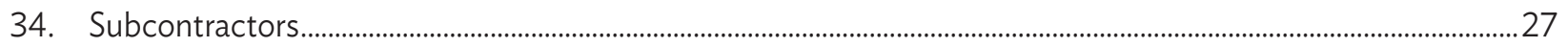

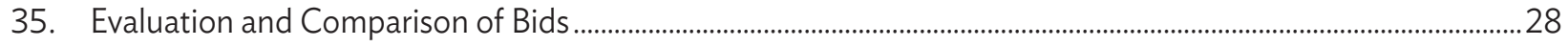

36. Abnormally Low Bids ..................................................................................................................................................2

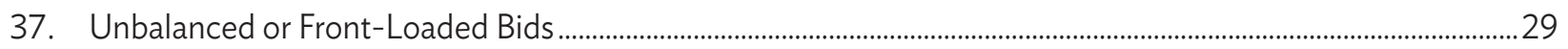

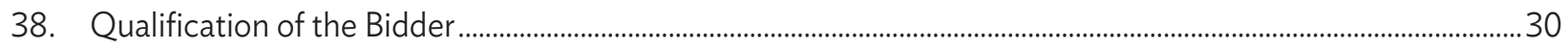

39. Employer's Right to Accept Any Bid, and to Reject Any or All Bids ...........................................................................30

40. Notice of Intention for Award of Contract..................................................................................................................... 


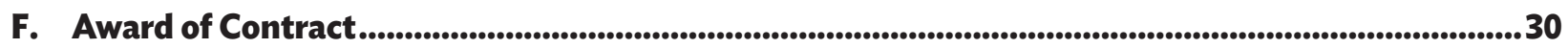

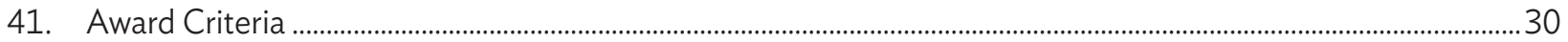

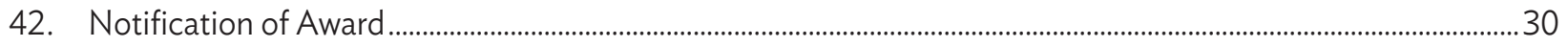

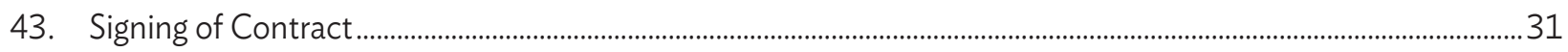

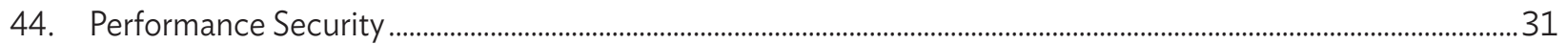

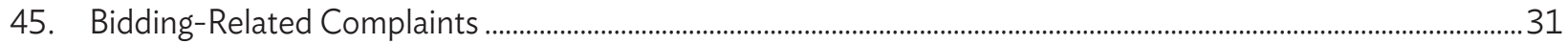


A. General

1. Scope of Bid

2. Source of Funds

\section{Fraud and Corruption}

1.1 In connection with the Invitation for Bids (IFB) indicated in the Bid Data Sheet (BDS), the Employer, as indicated in the BDS, issues this Bidding Document for the procurement of the Works as specified in Section 6 (Employer's Requirements). The name, identification, and number of contracts of this bidding are provided in the BDS.

1.2 Throughout this Bidding Document,

(a) the term "in writing" means communicated in written form and delivered against receipt;

(b) except where the context requires otherwise, words indicating the singular also include the plural and words indicating the plural also include the singular; and

(c) "day" means calendar day.

2.1 The Borrower or Recipient (hereinafter called "Borrower") indicated in the BDS has applied for or received financing (hereinafter called "funds") from the Asian Development Bank (hereinafter called "ADB") toward the cost of the project named in the BDS. The Borrower intends to apply a portion of the funds to eligible payments under the contract(s) for which this Bidding Document is issued.

2.2 Payments by ADB will be made only at the request of the Borrower and upon approval by $A D B$ in accordance with the terms and conditions of the Financing Agreement between the Borrower and ADB (hereinafter called "Financing Agreement"), and will be subject in all respects to the terms and conditions of that Financing Agreement. No party other than the Borrower shall derive any rights from the Financing Agreement or have any claim to the funds.

3.1 ADB requires Borrowers (including beneficiaries of ADB-financed activity) and their personnel, as well as firms and individuals participating in an ADB-financed activity, including but not limited to, Bidders, Suppliers, and Contractors, agents, subcontractors, subconsultants, service providers, subsuppliers, manufacturers (including their respective officers, directors, employees and personnel) under ADB-financed contracts to observe the highest standard of ethics during the procurement and execution of such contracts in accordance with ADB's Anticorruption Policy (1998, as amended from time to time). In pursuance of this policy, ADB

(a) defines, for the purposes of this provision, the terms set forth below as follows:

(i) "corrupt practice" means the offering, giving, receiving, or soliciting, directly or indirectly, anything of value to influence improperly the actions of another party;

(ii) "fraudulent practice" means any act or omission, including a misrepresentation, that knowingly or recklessly misleads, or attempts to mislead, a party to obtain a financial or other benefit or to avoid an obligation; 
(iii) "coercive practice" means impairing or harming, or threatening to impair or harm, directly or indirectly, any party or the property of the party to influence improperly the actions of a party;

(iv) "collusive practice" means an arrangement between two or more parties designed to achieve an improper purpose, including influencing improperly the actions of another party;

(v) "abuse" means theft, waste, or improper use of assets related to ADB-related activity, either committed intentionally or through reckless disregard;

(vi) "conflict of interest" means any situation in which a party has interests that could improperly influence that party's performance of official duties or responsibilities, contractual obligations, or compliance with applicable laws and regulations; and

(vii) "integrity violation" is any act, as defined under ADB's Integrity Principles and Guidelines (2015, as amended from time to time), which violates ADB's Anticorruption Policy, including (i) to (vi) above and the following: obstructive practice, violations of ADB sanctions, retaliation against whistleblowers or witnesses, and other violations of ADB's Anticorruption Policy, including failure to adhere to the highest ethical standard.

(b) will reject a proposal for award if it determines that the Bidder recommended for award or any of its officers, directors, employees, personnel, subconsultants, subcontractors, service providers, suppliers or manufacturers has, directly or through an agent, engaged in corrupt, fraudulent, collusive, coercive, or obstructive practices or other integrity violations in competing for the Contract;

(c) will cancel the portion of the financing allocated to a contract if it determines at any time that representatives of the Borrower or of a beneficiary of ADB financing engaged in corrupt, fraudulent, collusive, coercive, or obstructive practices or other integrity violations during the procurement or the execution of that contract, without the Borrower having taken timely and appropriate action satisfactory to $A D B$ to remedy the situation, including by failing to inform $A D B$ in a timely manner at the time they knew of the integrity violations;

(d) will impose remedial actions on a firm or an individual, at any time, in accordance with ADB's Anticorruption Policy and Integrity Principles and Guidelines, including declaring ineligible, either indefinitely or for a stated period of time, to participate ${ }^{1}$ in $A D B$-financed, -administered, or -supported activities or to benefit from an ADB-financed, -administered, or -supported contract, financially or otherwise, if it at any time determines that the firm or individual has, directly or through an agent, engaged in corrupt, fraudulent, collusive, coercive, or obstructive practices or other integrity violations; and

Whether as a Contractor, Subcontractor, Consultant, Manufacturer or Supplier, or Service Provider; or in any other capacity (different names are used depending on the particular Bidding Document). 
(e) will have the right to require that a provision be included in bidding documents and in contracts financed, administered, or supported by $A D B$, requiring Bidders, suppliers, and contractors, consultants, manufacturers, service providers and other third parties engaged or involved in ADB-related activities, and their respective officers, directors, employees and personnel, to permit $A D B$ or its representative to inspect the site and their assets, accounts and records and other documents relating to the bid submission and contract performance and to have them audited by auditors appointed by ADB.

3.2 All Bidders, consultants, contractors, suppliers, manufacturers, service providers, and other third parties engaged or involved in ADB-related activities, and their respective officers, directors, employees and personnel, are obliged to cooperate fully in any investigation when requested by ADB to do so. As determined on a case by case basis by $A D B$, such cooperation includes, but is not limited to, the following:

(a) being available to be interviewed and replying fully and truthfully to all questions asked;

(b) providing ADB with any items requested that are within the party's control including, but not limited to, documents and other physical objects;

(c) upon written request by $A D B$, authorizing other related entities to release directly to $A D B$ such information that is specifically and materially related, directly or indirectly, to the said entities or issues which are the subject of the investigation;

(d) cooperating with all reasonable requests to search or physically inspect their person and/or work areas, including files, electronic databases, and personal property used on ADB activities, or that utilizes ADB's Information and Communication Technology (ICT) resources or systems (including mobile phones, personal electronic devices, and electronic storage devices such as external disk drives);

(e) cooperating in any testing requested by $A D B$, including but not limited to, fingerprint identification, handwriting analysis, and physical examination and analysis; and

(f) preserving and protecting confidentiality of all information discussed with, and as required by, $\mathrm{ADB}$.

3.3 All Bidders, consultants, contractors and suppliers shall require their officers, directors, employees, personnel, agents to ensure that, in its contracts with its subconsultants, Subcontractors and other third parties engaged or involved in ADB-related activities, such subconsultants, Subcontractors and other third parties similarly are obliged to cooperate fully in any investigation when requested by $A D B$ to do so.

3.4 The Employer hereby puts the Bidder on notice that the Bidder or any Joint Venture partner of the Bidder (if any) may not be able to receive any payments under the Contract if the Bidder or any of its Joint Venture partners, as appropriate, is, or is owned (in whole or in part) by a person or entity subject to applicable sanctions.

3.5 Furthermore, Bidders shall be aware of the provisions of GCC 28.3 and 73.2(i). 
4. Eligible Bidders
4.1 A Bidder may be a natural person, private entity, or government-owned enterprises subject to ITB 4.5-or any combination of them with a formal intent to enter into an agreement or under an existing agreement in the form of a Joint Venture. In the case of a Joint Venture:

(a) all partners shall be jointly and severally liable; and

(b) the Joint Venture shall nominate a Representative who shall have the authority to conduct all business for and on behalf of any and all the parties of the Joint Venture during the bidding process and, in the event the Joint Venture is awarded the Contract, during contract execution.

4.2 A Bidder, and all parties constituting the Bidder, shall have the nationality of an eligible country, in accordance with Section 5 (Eligible Countries). A Bidder shall be deemed to have the nationality of a country if the Bidder is a citizen or is constituted, incorporated, or registered, and operates in conformity with the provisions of the laws of that country. This criterion shall also apply to the determination of the nationality of proposed Subcontractors or Suppliers for any part of the Contract including related services.

4.3 A Bidder shall not have a conflict of interest. All Bidders found to have a conflict of interest shall be disqualified. A Bidder may be considered to be in a conflict of interest with one or more parties in this bidding process if any of, including but not limited to, the following apply:

(a) they have controlling shareholders in common; or

(b) they receive or have received any direct or indirect subsidy from any of them; or

(c) they have the same legal representative for purposes of this bid; or

(d) they have a relationship with each other, directly or through common third parties, that puts them in a position to have access to material information about or improperly influence the Bid of another Bidder, or influence the decisions of the Employer regarding this bidding process; or

(e) a Bidder participates in more than one bid in this bidding process, either individually or as a partner in a Joint Venture, except for alternative offers permitted under ITB 13 of the Bidding Document. This will result in the disqualification of all Bids in which it is involved. However, subject to any finding of a conflict of interest in terms of ITB 4.3 (a)-(d) above, this does not limit the participation of a Bidder as a Subcontractor in another Bid or of a firm as a Subcontractor in more than one Bid; or

(f) a Bidder, Joint Venture partner, associates, parent company, or any affiliated entity, participated as a Consultant in the preparation of the design or technical specifications of the works that are the subject of the Bid; or 
(g) a Bidder was affiliated with a firm or entity that has been hired (or is proposed to be hired) by the Employer or Borrower as Engineer for the Contract; or

(h) a Bidder would be providing goods, works, or nonconsulting services resulting from or directly related to consulting services for the preparation or implementation of the project specified in the BDS ITB 2.1 that it provided or were provided by any affiliate that directly or indirectly controls, is controlled by, or is under common control with that firm; or

(i) a Bidder that has a financial or familial relationship with staff of the Employer including project implementing/executing agency, or of a recipient of a part of the loan who: (i) are directly or indirectly involved in the preparation of the bidding documents or specifications of the contract, and/or the bid evaluation process of such contract; or (ii) would be involved in the implementation or supervision of such contract unless the conflict stemming from such relationship has been resolved in a manner acceptable to ADB throughout the procurement process and execution of the contract.

4.4 A firm will not be eligible to participate in any procurement activities under an ADB-financed, -administered, or -supported project while under temporary suspension or debarment by ADB pursuant to its Anticorruption Policy (see ITB 3), whether such debarment was directly imposed by ADB, or enforced by ADB pursuant to the Agreement for Mutual Enforcement of Debarment Decisions. A bid from a temporarily suspended or debarred firm will be rejected and such bid may be in breach of debarment conditions, thereby subject to further ADB's investigation.

4.5 Government-owned enterprises in the Employer's country shall be eligible only if they can establish that they (i) are legally and financially autonomous, (ii) operate under commercial law, and (iii) are not a dependent agency of the Employer.

4.6 A Bidder shall not be under suspension from Bidding by the Employer as the result of the execution of a Bid-Securing Declaration.

4.7 Bidders shall provide such evidence of their continued eligibility satisfactory to the Employer, as the Employer shall reasonably request.

4.8 Bidders shall be excluded if, by an act of compliance with a decision of the United Nations Security Council taken under Chapter VII of the Charter of the United Nations, the Borrower's country prohibits any import of goods from, or payments to, a particular country, person, or entity in respect of goods or services originating in that country. Where the Borrower's country prohibits payments to a particular person or entity or for particular goods or services by such an act of compliance, that firm shall be excluded. 
5. Eligible Materials, 5.1 The materials, equipment, and services to be supplied under the Contract Equipment, and shall have their origin in eligible source countries as defined in ITB 4.2 and all expenditures under the Contract will be limited to such materials, equipment, and services. At the Employer's request, Bidders may be required to provide evidence of the origin of materials, equipment, and services.

5.2 For purposes of ITB 5.1 above, "origin" means the place where the materials and equipment are mined, grown, produced, or manufactured, and from which the services are provided. Materials and equipment are produced when, through manufacturing, processing, or substantial or major assembling of components, a commercially recognized product results that differs substantially in its basic characteristics or in purpose or utility from its components.

\section{B. Contents of Bidding Document}

6. Sections of Bidding Document
6.1 The Bidding Document consists of Parts I, II, and III, which include all the sections indicated below, and should be read in conjunction with any addenda issued in accordance with ITB 8.

\section{PART I Bidding Procedures}

- Section 1 Instructions to Bidders (ITB)

- Section 2 Bid Data Sheet (BDS)

- Section 3 Evaluation and Qualification Criteria (EQC)

- Section 4 Bidding Forms (BDF)

- Section 5 Eligible Countries (ELC)

\section{PART II Requirements}

- Section 6 Employer's Requirements (ERQ)

\section{PART III Conditions of Contract and Contract Forms}

- Section 7 General Conditions of Contract (GCC)

- Section 8 Particular Conditions of Contract (PCC)

- Section 9 Contract Forms (COF)

6.2 The IFB issued by the Employer is not part of the Bidding Document.

6.3 The Employer is not responsible for the completeness of the Bidding Document and their addenda, if they were not obtained directly from the source stated by the Employer in the IFB.

6.4 The Bidder is expected to examine all instructions, forms, terms, and specifications in the Bidding Document. Failure to furnish all information or documentation required by the Bidding Document may result in the rejection of the bid. 
7. Clarification of Bidding Document, Site Visit, Pre-Bid Meeting
7.1 A prospective Bidder requiring any clarification on the Bidding Document shall contact the Employer in writing at the Employer's address indicated in the BDS or raise his inquiries during the pre-bid meeting if provided for in accordance with ITB 7.4. The Employer will respond in writing to any request for clarification, provided that such request is received prior to the deadline for submission of bids, within a period given in the BDS. The Employer shall forward copies of its response to all Bidders who have acquired the Bidding Document in accordance with ITB 6.3, including a description of the inquiry but without identifying its source. Should the Employer deem it necessary to amend the Bidding Document as a result of a request for clarification, it shall do so following the procedure under ITB 8 and ITB 22.2.

7.2 The Bidder is advised to visit and examine the Site of Works and its surroundings and obtain for itself, on its own risk and responsibility, all information that may be necessary for preparing the Bid and entering into a contract for construction of the Works. The costs of visiting the Site shall be at the Bidder's own expense.

7.3 The Bidder and any of its personnel or agents will be granted permission by the Employer to enter its premises and lands for the purpose of such visit, but only upon the express condition that the Bidder, its personnel, and agents will release and indemnify the Employer and its personnel and agents from and against all liability in respect thereof, and will be responsible for death or personal injury, loss of or damage to property, and any other loss, damage, costs, and expenses incurred as a result of the inspection.

7.4 The Bidder's designated representative is invited to attend a pre-bid meeting, if provided for in the BDS. The purpose of the meeting will be to clarify issues and to answer questions on any matter that may be raised at that stage.

7.5 The Bidder is requested to submit any questions in writing, to reach the Employer not later than 1 week before the meeting.

7.6 Minutes of the pre-bid meeting, including the text of the questions raisedwithout identifying the source-and the responses given, together with any responses prepared after the meeting, will be transmitted promptly to all Bidders who have acquired the Bidding Document in accordance with ITB 6.3. Any modification to the Bidding Document that may become necessary as a result of the pre-bid meeting shall be made by the Employer exclusively through the issue of an addendum pursuant to ITB 8 and not through the minutes of the pre-bid meeting.

7.7 Nonattendance at the pre-bid meeting will not be a cause for disqualification of a Bidder. 


\section{Amendment of Bidding Document}

\section{Preparation of Bids}

9. Cost of Bidding

10. Language of Bid

8.1 At any time prior to the deadline for submission of Bids, the Employer may amend the Bidding Document by issuing addenda.

8.2 Any addendum issued shall be part of the Bidding Document and shall be communicated in writing to all who have obtained the Bidding Document from the Employer in accordance with ITB 6.3.

8.3 To give prospective Bidders reasonable time in which to take an addendum into account in preparing their Bids, the Employer may, at its discretion, extend the deadline for the submission of Bids, pursuant to ITB 22.2.

9.1 The Bidder shall bear all costs associated with the preparation and submission of its Bid, and the Employer shall in no case be responsible or liable for those costs, regardless of the conduct or outcome of the bidding process.

10.1 The Bid, as well as all correspondence and documents relating to the bid exchanged by the Bidder and the Employer, shall be written in the language specified in the BDS. Supporting documents and printed literature that are part of the Bid may be in another language provided they are accompanied by an accurate translation of the relevant passages in the language specified in the BDS, in which case, for purposes of interpretation of the Bid, such translation shall govern.

11. Documents Comprising the Bid
11.1 The Bid shall comprise the following:

(a) Letter of Bid;

(b) completed Schedules, in accordance with ITB 12 and ITB 14, or as stipulated in the BDS;

(c) Bid Security or Bid-Securing Declaration, in accordance with ITB 19;

(d) alternative Bids, at Bidder's option and if permissible, in accordance with ITB 13;

(e) written confirmation authorizing the signatory of the Bid to commit the Bidder, in accordance with ITB 20.2;

(f) documentary evidence in accordance with ITB 17, establishing the Bidder's qualifications to perform the contract;

(g) Technical Proposal in accordance with ITB 16; and

(h) any other document required in the BDS.

11.2 In addition to the requirements under ITB 11.1, Bids submitted by a Joint Venture shall include a copy of the Joint Venture Agreement entered into by all partners. Alternatively, a Letter of Intent to execute a Joint Venture Agreement in the event of a successful Bid shall be signed by all partners and submitted with the Bid, together with a copy of the proposed agreement. 
12. Letter of Bid and Schedules

13. Alternative Bids

14. Bid Prices and Discounts
12.1 The Letter of Bid, Schedules, and all documents listed under Clause 11, shall be prepared using the relevant forms in Section 4 (Bidding Forms), if so provided. The forms must be completed without any alterations to the text, and no substitutes shall be accepted. All blank spaces shall be filled in with the information requested and as required in the BDS.

13.1 Unless otherwise indicated in the BDS, alternative Bids shall not be considered.

13.2 When alternative times for completion are explicitly invited, a statement to that effect will be included in the BDS, as will the method of evaluating different times for completion.

13.3 When specified in the BDS pursuant to ITB 13.1, and subject to ITB 13.4 below, Bidders wishing to offer technical alternatives to the requirements of the Bidding Document must first price the Employer's design as described in the Bidding Document and shall further provide all information necessary for a complete evaluation of the alternative by the Employer, including drawings, design calculations, technical specifications, breakdown of prices, and proposed construction methodology, and other relevant details. Only the technical alternatives, if any, of the lowest evaluated Bidder conforming to the basic technical requirements shall be considered by the Employer.

13.4 When specified in the BDS, Bidders are permitted to submit alternative technical solutions for specified parts of the Works. Such parts will be identified in the BDS and described in Section 6 (Employer's Requirements). The method for their evaluation will be stipulated in Section 3 (Evaluation and Qualification Criteria).

14.1 The prices and discounts quoted by the Bidder in the Letter of Bid and in the Schedules shall conform to the requirements specified below.

14.2 The Bidder shall submit a bid for the whole of the works described in ITB 1.1 by filling in prices for all items of the Works, as identified in Section 4 (Bidding Forms). In case of admeasurement contracts, the Bidder shall fill in rates and prices for all items of the Works described in the Bill of Quantities. Items against which no rate or price is entered by the Bidder will not be paid for by the Employer when executed and shall be deemed covered by the rates for other items and prices in the Bill of Quantities. Unit rates and prices for all items of the Works described in the Bill of Quantities shall be expressed in positive values. If unit rates and prices are expressed in negative values, the bid will be rejected.

14.3 The price to be quoted in the Letter of Bid shall be the total price of the Bid, excluding any discounts offered. Absence of the total bid price in the Letter of Bid may result in the rejection of the Bid.

14.4 The Bidder shall quote any discounts and the methodology for their application in the Letter of Bid, in accordance with ITB 12.1.

14.5 The prices shall be either fixed or adjustable as specified in the BDS.

(a) In the case of Fixed Price, prices quoted by the Bidder shall be fixed during the Bidder's performance of the contract and not subject to variation on any account. A Bid submitted with an adjustable price will be treated as nonresponsive and rejected. 
(b) In the case of Adjustable Price, prices quoted by the Bidder shall be subject to adjustment during performance of the contract to reflect changes in the cost elements such as labor, material, transport, and contractor's equipment in accordance with the provisions of the Conditions of Contract. A Bid submitted with a fixed price will be treated as nonresponsive and be rejected. The Bidder shall furnish the indexes and weightings for the price adjustment formulas in the Tables of Adjustment Data included in Section 4 (Bidding Forms) and the Employer may require the Bidder to justify its proposed indexes and weightings. Any bid that omits indexes and weightings shall be subject to clarification with the Bidder.

14.6 If so indicated in ITB 1.1, bids are invited for individual contracts or for any combination of contracts (packages). Bidders wishing to offer any price reduction for the award of more than one Contract shall specify in their bid the price reductions applicable to each package, or alternatively, to individual Contracts within the package. Price reductions or discounts shall be submitted in accordance with ITB 14.4, provided the Bids for all contracts are submitted and opened at the same time.

14.7 All duties, taxes, and other levies payable by the Contractor under the Contract, or for any other cause, as of the date 28 days prior to the deadline for submission of bids, shall be included in the rates and prices and the total bid price submitted by the Bidder.

15. Currencies of Bid and Payment

\section{Documents Comprising the Technical Proposal}

\section{Documents Establishing the Qualifications of the Bidder}

15.1 The currency(ies) of the Bid and payment shall be as specified in the BDS.

15.2 Bidders may be required by the Employer to justify, to the Employer's satisfaction, their local and foreign currency requirements, and to substantiate that the amounts included in the prices shown in the appropriate form(s) of Section 4, in which case a detailed breakdown of the foreign currency requirements shall be provided by Bidders.

16.1 The Bidder shall furnish a Technical Proposal including a statement of work methods, equipment, personnel, schedule, environmental, health and safety (EHS) management plan commensurate with the proposed scope of works, EHS Code of Conduct, and any other information stipulated in Section 4 (Bidding Forms), in sufficient detail to demonstrate the adequacy of the Bidders' proposal to meet the work requirements and the completion time.

17.1 To establish its qualifications to perform the Contract in accordance with Section 3 (Evaluation and Qualification Criteria), the Bidder shall provide the information requested in the corresponding information sheets included in Section 4 (Bidding Forms).

17.2 Domestic Bidders, individually or in Joint Ventures, applying for eligibility for domestic preference shall supply all information required to satisfy the criteria for eligibility as described in ITB 33. 


\section{Period of Validity of Bids}

\section{Bid Security/ Bid-Securing Declaration}

18.1 Bids shall remain valid for the bid validity period specified in the BDS. The bid validity period starts from the date fixed for the bid submission deadline date prescribed by the Employer in accordance with ITB 22.1. A bid valid for a shorter period shall be rejected by the Employer as nonresponsive.

18.2 In exceptional circumstances, prior to the expiration of the bid validity period, the Employer may request Bidders to extend the period of validity of their Bids. The request and the responses shall be made in writing. If a bid security is requested in accordance with ITB 19, it shall also be extended 28 days beyond the deadline of the extended bid validity period. A Bidder may refuse the request without forfeiting its bid security. A Bidder granting the request shall not be required or permitted to modify its Bid.

19.1 Unless otherwise specified in the BDS, the Bidder shall furnish as part of its Bid, in original form, either a Bid-Securing Declaration or a bid security as specified in the BDS. In the case of a bid security, the amount and currency shall be as specified in the BDS.

19.2 If a Bid-Securing Declaration is required pursuant to ITB 19.1, it shall use the form included in Section 4 (Bidding Forms). The Employer will declare a Bidder ineligible to be awarded a Contract for a specified period of time, as indicated in the BDS, if a Bid-Securing Declaration is executed.

19.3 If a bid security is specified pursuant to ITB 19.1, the bid security shall be, at the Bidder's option, in any of the following forms:

(a) an unconditional bank guarantee (hard copy of the bank guarantee or in the form of SWIFT message MT760), or

(b) an irrevocable letter of credit, or

(c) a cashier's or certified check.

all from a reputable source from an eligible country as described in Section 5 (Eligible Countries). In the case of a bank guarantee, the bid security shall be submitted either using the Bid Security Form included in Section 4 (Bidding Forms) or another form acceptable to the Employer. The form must include the complete name of the Bidder. The bid security shall be valid for 28 days beyond the original validity period of the bid, or beyond any period of extension if requested under ITB 18.2.

19.4 Unless otherwise specified in the BDS, any Bid not accompanied by a substantially compliant bid security or Bid-Securing Declaration, if one is required in accordance with ITB 19.1, shall be rejected by the Employer as nonresponsive.

19.5 If a bid security is specified pursuant to ITB 19.1, the bid security of unsuccessful Bidders shall be returned promptly upon the successful Bidder's furnishing of the performance security pursuant to ITB 44.

19.6 If a bid security is specified pursuant to ITB 19.1, the bid security of the successful Bidder shall be returned promptly once the successful Bidder has signed the Contract and furnished the required performance security. 
19.7 The bid security may be forfeited or the Bid-Securing Declaration executed, if

(a) notwithstanding ITB 24.3, a Bidder withdraws its bid during the period of bid validity specified by the Bidder on the Letter of Bid, except as provided in ITB 18.2; or

(b) the successful Bidder fails to

(i) sign the Contract in accordance with ITB 43;

(ii) furnish a performance security in accordance with ITB 44;

(iii) accept arithmetical corrections in accordance with ITB 31; or

(iv) furnish a domestic preference security, if applicable, in accordance with ITB 44.3.

19.8 If the bid security is required as per ITB 19.1, the bid security of a Joint Venture shall be in the name of the Joint Venture that submits the Bid. If the Joint Venture has not been legally constituted at the time of bidding, the bid security shall be in the name of any or all of the Joint Venture partners. If the Bid-Securing Declaration is required as per ITB 19.1, the Bid-Securing Declaration of a Joint Venture shall be in the name of the Joint Venture that submits the Bid. If the Joint Venture has not been legally constituted the time of bidding, the Bid-Securing Declaration shall be in the names of all future partners as named in the letter of intent mentioned in ITB 4.1.

20. Format and Signing of Bid
20.1 The Bidder shall prepare one original set of the documents comprising the Bid as described in ITB 11 and clearly mark it "ORIGINAL." Alternative Bids, if permitted in accordance with ITB 13, shall be clearly marked "ALTERNATIVE." In addition, the Bidder shall submit copies of the Bid in the number specified in the BDS, and clearly mark each of them "COPY." In the event of any discrepancy between the original and the copies, the original shall prevail.

20.2 The original and all copies of the Bid shall be typed or written in indelible ink and shall be signed by a person duly authorized to sign on behalf of the Bidder. This authorization shall consist of a written confirmation as specified in the BDS and shall be attached to the Bid. The name and position held by each person signing the authorization must be typed or printed below the signature. If a Bidder submits a deficient authorization, the Bid shall not be rejected in the first instance. The Employer shall request the Bidder to submit an acceptable authorization within the number of days as specified in the BDS. Failure to provide an acceptable authorization within the period stated in the Employer's request shall cause the rejection of the Bid. If either the Letter of Bid or the Bid-Securing Declaration (if applicable) is not signed, the Bid shall be rejected.

20.3 Any amendments such as interlineations, erasures, or overwriting shall be valid only if they are signed or initialed by the person signing the Bid. 


\section{Submission and Opening of Bids}

\section{Sealing and Marking of Bids}

22. Deadline for Submission of Bids

\section{Late Bids}

21.1 Bidders shall submit their Bids as specified in the BDS. Procedures for submission, sealing, and marking are as follows:

(a) Bidders submitting Bids by mail or by hand shall enclose the original and each copy of the Bid, including alternative Bids, if permitted in accordance with ITB 13, in separate sealed envelopes, duly marking the envelopes as "ORIGINAL," "ALTERNATIVE," and "COPY." These envelopes containing the original and the copies shall then be enclosed in one single envelope. The rest of the procedure shall be in accordance with ITB 21.2 and ITB 21.3.

(b) Bidders submitting Bids electronically shall follow the electronic bid submission procedures specified in the BDS.

21.2 The inner and outer envelopes shall

(a) bear the name and address of the Bidder;

(b) be addressed to the Employer as provided in BDS 22.1;

(c) bear the specific identification of this bidding process indicated in BDS 1.1; and

(d) bear a warning not to open before the time and date for bid opening.

21.3 If all envelopes are not sealed and marked as required, the Employer will assume no responsibility for the misplacement or premature opening of the Bid.

22.1 Bids must be received by the Employer at the address and no later than the date and time indicated in the BDS.

22.2 The Employer may, at its discretion, extend the deadline for the submission of Bids by amending the Bidding Document in accordance with ITB 8, in which case all rights and obligations of the Employer and Bidders previously subject to the deadline shall thereafter be subject to the deadline as extended.

23.1 The Employer shall not consider any Bid that arrives after the deadline for submission of bids, in accordance with ITB 22. Any Bid received by the Employer after the deadline for submission of Bids shall be declared late, rejected, and returned unopened to the Bidder. 
24. Withdrawal, Substitution, and Modification of Bids
24.1 A Bidder may withdraw, substitute, or modify its Bid after it has been submitted by sending a written notice, duly signed by an authorized representative, and shall include a copy of the authorization in accordance with ITB 20.2 (except for withdrawal notices, which do not require copies). The corresponding substitution or modification of the Bid must accompany the respective written notice. All notices must be

(a) prepared and submitted in accordance with ITB 20 and ITB 21 (except for withdrawal notices, which do not require copies), and in addition, the respective envelopes shall be clearly marked "WITHDRAWAL," "SUBSTITUTION," "MODIFICATION;" and

(b) received by the Employer prior to the deadline prescribed for submission of Bids, in accordance with ITB 22.

24.2 Bids requested to be withdrawn in accordance with ITB 24.1 shall be returned unopened to the Bidders.

24.3 No Bid may be withdrawn, substituted, or modified in the interval between the deadline for submission of Bids and the expiration of the period of bid validity specified by the Bidder on the Letter of Bid or any extension thereof.

25.1 The Employer shall open the Bids in public at the address, on the date, and time specified in the BDS in the presence of Bidders' designated representatives and anyone who choose to attend. Any specific electronic bid opening procedures required if electronic bidding is permitted in accordance with ITB 21.1, shall be as specified in the BDS.

25.2 First, envelopes marked "WITHDRAWAL" shall be opened and read out and the envelope with the corresponding Bid shall not be opened, but returned to the Bidder. No bid withdrawal shall be permitted unless the corresponding withdrawal notice contains a valid authorization to request the withdrawal and is read out at bid opening. Next, envelopes marked "SUBSTITUTION" shall be opened and read out and exchanged with the corresponding Bid being substituted. The substituted Bid shall not be opened, but returned to the Bidder. No bid substitution shall be permitted unless the corresponding substitution notice contains a valid authorization to request the substitution and is read out at bid opening. Envelopes marked "MODIFICATION" shall be opened and read out with the corresponding Bid. No bid modification shall be permitted unless the corresponding modification notice contains a valid authorization to request the modification and is read out at bid opening. Only envelopes that are opened and read out at bid opening shall be considered further. 
25.3 All other envelopes shall be opened one at a time, reading out the name of the Bidder; the Bid Price(s), including any discounts and alternative bids and indicating whether there is a modification; the presence of a bid security or Bid-Securing Declaration, if required; and any other details as the Employer may consider appropriate. Only discounts and alternative offers read out at bid opening shall be considered for evaluation. Unless otherwise specified in the BDS, all pages of the Letter of Bid and Schedules are to be initialed by at least three representatives of the Employer attending the bid opening. No Bid shall be rejected at bid opening except for late Bids, in accordance with ITB 23.1.

25.4 The Employer shall prepare a record of the bid opening that shall include, as a minimum, the name of the Bidder and whether there is a withdrawal, substitution, or modification; the Bid Price, per contract if applicable, including any discounts and alternative offers; and the presence or absence of a bid security or a Bid-Securing Declaration, if one was required. The Bidders' representatives who are present shall be requested to sign the record. The omission of a Bidder's signature on the record shall not invalidate the contents and effect of the record. A copy of the record shall be distributed to all Bidders who submitted Bids on time, and posted online when electronic bidding is permitted.

\section{E. Evaluation and Comparison of Bids}

26. Confidentiality 26.1 Information relating to the examination, evaluation, comparison, and postqualification of Bids and recommendation of contract award, shall not be disclosed to Bidders or any other persons not officially concerned with such process until the publication of Contract award.

26.2 Any attempt by a Bidder to influence the Employer in the evaluation of the Bids or Contract award decisions may result in the rejection of its Bid.

26.3 Notwithstanding ITB 26.2, from the time of bid opening to the time of Contract award, if any Bidder wishes to contact the Employer on any matter related to the bidding process, it may do so in writing.

\section{Clarification} of Bids
27.1 To assist in the examination, evaluation, and comparison of the bids, and qualification of the Bidders, the Employer may, at its discretion, ask any Bidder for a clarification of its Bid. Any clarification submitted by a Bidder that is not in response to a request by the Employer shall not be considered. The Employer's request for clarification and the response shall be in writing. No change in the prices or substance of the Bid shall be sought, offered, or permitted, except to confirm the correction of arithmetic errors discovered by the Employer in the evaluation of the Bids, in accordance with ITB 31.

27.2 If a Bidder does not provide clarifications of its Bid by the date and time set in the Employer's request for clarification, its Bid may be rejected. 
28. Deviations, Reservations, and Omissions

29. Determination of Responsiveness
28.1 During the evaluation of Bids, the following definitions apply:

(a) "Deviation" is a departure from the requirements specified in the Bidding Document;

(b) "Reservation" is the setting of limiting conditions or withholding from complete acceptance of the requirements specified in the Bidding Document; and

(c) "Omission" is the failure to submit part or all of the information or documentation required in the Bidding Document.

29.1 The Employer's determination of a Bid's responsiveness is to be based on the contents of the Bid itself, as defined in ITB 11.

29.2 A substantially responsive Bid is one that meets the requirements of the Bidding Document without material deviation, reservation, or omission. A material deviation, reservation, or omission is one that,

(a) if accepted, would

(i) affect in any substantial way the scope, quality, or performance of the Works specified in the Contract; or

(ii) limit in any substantial way, inconsistent with the Bidding Document, the Employer's rights or the Bidder's obligations under the proposed Contract; or

(b) if rectified, would unfairly affect the competitive position of other Bidders presenting substantially responsive Bids.

29.3 The Employer shall examine the technical aspects of the Bid submitted in accordance with ITB 16, Technical Proposal, in particular, to confirm that all requirements of Section 6 (Employer's Requirements) have been met without any material deviation, reservation, or omission.

29.4 If a Bid is not substantially responsive to the requirements of the Bidding Document, it shall be rejected by the Employer and may not subsequently be made responsive by correction of the material deviation, reservation, or omission.

30.1 Provided that a Bid is substantially responsive, the Employer may waive any nonconformities in the Bid that do not constitute a material deviation, reservation, or omission.

30.2 Provided that a Bid is substantially responsive, the Employer may request that the Bidder submit the necessary information or documentation, within a reasonable period of time, to rectify nonmaterial nonconformities in the Bid related to documentation requirements. Requesting information or documentation on such nonconformities shall not be related to any aspect of the price of the Bid. Failure of the Bidder to comply with the request may result in the rejection of its Bid. 


\section{Correction of Arithmetical Errors}

\section{Conversion to Single Currency}

\section{Domestic} Preference

34. Subcontractors
30.3 Provided that a Bid is substantially responsive, the Employer shall rectify quantifiable nonmaterial nonconformities related to the Bid Price. To this effect, the Bid Price may be adjusted, for comparison purposes only, to reflect the price of a missing or nonconforming item or component. The adjustment shall be made using the methods indicated in Section 3 (Evaluation and Qualification Criteria).

31.1 Provided that the Bid is substantially responsive, the Employer shall correct arithmetical errors on the following basis:

(a) Only for admeasurement contracts, if there is a discrepancy between the unit price and the total price that is obtained by multiplying the unit price and quantity, the unit price shall prevail and the total price shall be corrected, unless in the opinion of the Employer there is an obvious misplacement of the decimal point in the unit price, in which case the total price as quoted shall govern and the unit price shall be corrected.

(b) If there is an error in a total corresponding to the addition or subtraction of subtotals, the subtotals shall prevail and the total shall be corrected.

(c) If there is a discrepancy between the bid price in the Summary of Bill of Quantities and the bid amount in item (c) of the Letter of Bid, the bid price in the Summary of Bill of Quantities will prevail and the bid amount in item (c) of the Letter of Bid will be corrected.

(d) If there is a discrepancy between words and figures, the amount in words shall prevail, unless the amount expressed in words is related to an arithmetic error, in which case the amount in figures shall prevail subject to (a), (b) and (c) above.

31.2 If the Bidder that submitted the lowest evaluated bid does not accept the correction of errors, its bid shall be disqualified and its bid security may be forfeited, or its Bid-Securing Declaration executed.

32.1 For evaluation and comparison purposes, the currency(ies) of the Bid shall be converted into a single currency as specified in the BDS.

33.1 Unless otherwise specified in the BDS, domestic preference shall not apply.

34.1 Unless otherwise stated in the BDS, the Employer does not intend for the contractor to execute any specific elements of the Works through nominated Subcontractors.

34.2 If Subcontractors are proposed for any of the key activities listed in Section 3 (Evaluation and Qualification Criteria) 2.4.2, they shall be considered as "Specialist Subcontractors" and shall meet qualification requirements for the relevant key activities. 
35. Evaluation and Comparison of Bids
36. Abnormally Low Bids
35.1 The Employer shall use the criteria and methodologies listed in this Clause. No other evaluation criteria or methodologies shall be permitted.

35.2 To evaluate a Bid, the Employer shall consider the following:

(a) the bid price, excluding Provisional Sums and the provision, if any, for contingencies in the Summary Bill of Quantities for admeasurement contracts, or Activity Schedule for lump sum contracts, but including Daywork items, where priced competitively;

(b) price adjustment for correction of arithmetic errors in accordance with ITB 31.1;

(c) price adjustment due to discounts offered in accordance with ITB 14.4;

(d) converting the amount resulting from applying (a) to (c) above, if relevant, to a single currency in accordance with ITB 32;

(e) adjustment for nonmaterial nonconformities in accordance with ITB 30.3;

(f) assessment whether the bid is abnormally low in accordance with ITB 36; and

(g) application of all the evaluation factors indicated in Section 3 (Evaluation and Qualification Criteria).

35.3 The estimated effect of the price adjustment provisions of the Conditions of Contract, applied over the period of execution of the Contract, shall not be taken into account in bid evaluation.

35.4 If this Bidding Document allows Bidders to quote separate prices for different contracts, and to award multiple contracts to a single Bidder, the methodology to determine the lowest evaluated price of the contract combinations, including any discounts offered in the Letter of Bid, is specified in Section 3 (Evaluation and Qualification Criteria).

35.5 The Employer shall compare all substantially responsive Bids to determine the lowest evaluated Bid, in accordance with ITB 35.2.

36.1 An abnormally low bid is one where the bid price, in combination with other elements of the bid, appears to be so low that it raises concerns as to the capability of the Bidder to perform the contract for the offered bid price.

36.2 When the offered bid price appears to be abnormally low, the Employer shall undertake a three-step review process as follows:

(a) identify abnormally low costs and unit rates by comparing them with the engineer's estimates, other substantially responsive bids, or recently awarded similar contracts; 
(b) clarify and analyze the bidder's resource inputs and pricing, including overheads, contingencies and profit margins; and

(c) decide whether to accept or reject the bid.

36.3 With regard to ITB 36.2 (b) above, the Employer will seek a written explanation from the bidder of the reasons for the offered bid price, including a detailed analysis of costs and unit prices, by reference to the scope, proposed methodology, schedule, and allocation of risks and responsibilities. This may also include information regarding the economy of the manufacturing process; the services to be provided, or the construction method to be used; the technical solutions to be adopted; and any exceptionally favorable conditions available to the bidder for the works, equipment or services proposed.

36.4 After examining the explanation given and the detailed price analyses presented by the bidder, the Employer may:

(a) accept the bid, if the evidence provided satisfactorily accounts for the low bid price and costs, in which case the bid is not considered abnormally low;

(b) accept the bid, but require that the amount of the performance security be increased at the expense of the bidder to a level sufficient to protect the Employer against financial loss. The amount of the performance security shall generally be not more than $20 \%$ of the contract price; or

(c) reject the bid if the evidence provided does not satisfactorily account for the low bid price, and make a similar determination for the next ranked bid, if required.

37. Unbalanced or Front-Loaded Bids
37.1 If the Bid, which results in the lowest evaluated Bid Price, is seriously unbalanced or front loaded in the opinion of the Employer, the Employer may require the Bidder to produce detailed price analyses for any or all items of the Bill of Quantities, to demonstrate the internal consistency of those prices with the construction methods and schedule proposed, as well as the pricing and sources of materials, equipment and labor.

37.2 After the evaluation of the information and detailed price analyses presented by the Bidder, the Employer may as appropriate:

(a) accept the Bid; or

(b) accept the Bid, but require that the total amount of the Performance Security be increased at the expense of the Bidder to a level sufficient to protect the Employer against financial loss in the event of default of the successful Bidder under the Contract subject to ITB 44.2; or

(c) reject the Bid and make a similar determination for the next ranked bid. 
38. Qualification of the Bidder

39. Employer's Right to Accept Any Bid, and to Reject Any or All Bids

40. Notice of Intention for Award of Contract

\section{F. Award of Contract}

38.1 The Employer shall determine to its satisfaction whether the Bidder that is selected as having submitted the lowest evaluated and substantially responsive Bid meets the qualifying criteria specified in Section 3 (Evaluation and Qualification Criteria).

38.2 The determination shall be based upon an examination of the documentary evidence of the Bidder's qualifications submitted by the Bidder, pursuant to ITB 17.1. Unless permitted in the BDS, the determination shall not take into consideration the qualifications of other firms such as the Bidder's subsidiaries, parent entities, or affiliates.

38.3 An affirmative determination shall be a prerequisite for award of the Contract to the Bidder. The Employer reserves the right to reject the bid of any Bidder found to be in circumstances described in GCC 73.2(c). A negative determination shall result in disqualification of the Bid, in which event the Employer shall proceed to the next lowest evaluated bid to make a similar determination of that Bidder's qualifications to perform satisfactorily.

39.1 The Employer reserves the right to accept or reject any Bid, and to annul the bidding process and reject all Bids at any time prior to contract award, without thereby incurring any liability to Bidders. In case of annulment, all Bids submitted and specifically, bid securities, shall be promptly returned to the Bidders.

40.1 If Standstill provisions apply as specified in the BDS, the standstill period shall be defined in the BDS to specify the duration subsequent to notification of intention for award of contract (before making the actual contract award) within which any unsuccessful Bidder can challenge the proposed award.
41. Award Criteria

\section{Notification of Award}

41.1 The Employer shall award the Contract to the Bidder whose offer has been determined in line with ITB 35 to ITB 37 above to be the lowest evaluated Bid and is substantially responsive to the Bidding Document, provided further that the Bidder is determined to be qualified to perform the Contract satisfactorily.

42.1 Prior to the expiration of the period of bid validity and upon expiry of the standstill period specified in ITB 40.1, or upon satisfactory resolution of a complaint filed within standstill period, if applicable, the Employer shall transmit the Notification of Award through issuance of Letter of Acceptance using the form included in Section 9 (Contract Forms) to the successful Bidder, in writing, that its Bid has been accepted. At the same time, the Employer shall also notify all other Bidders of the results of the bidding.

42.2 Unless standstill period applies, upon notification of award through issuance of Letter of Acceptance, unsuccessful Bidders may request in writing to the Employer for a debriefing seeking explanations on the grounds on which their Bids were not selected. The Employer shall promptly respond in writing and/or in a debriefing meeting to any unsuccessful Bidder who, after publication of contract award, requests a debriefing. 
42.3 Until a formal contract is prepared and executed, the notification of award through issuance of Letter of Acceptance shall constitute a binding Contract.

42.4 Within 2 weeks of the award of contract or expiry of the standstill period, where such period applies, or, if a complaint has been filed within the standstill period, upon receipt of ADB's confirmation of satisfactory resolution of the complaint, the Borrower shall publish in an English language newspaper or widely known and freely accessible website the results identifying the bid and lot or package numbers, as applicable and the following information:

(a) name of each Bidder who submitted a Bid;

(b) bid prices as read out at bid opening;

(c) name and evaluated prices of each Bid that was evaluated;

(d) name of Bidders whose bids were rejected and the reasons for their rejection; and

(e) name of the winning Bidder, and the price it offered, as well as the duration and summary scope of the contract awarded.

\section{Signing of Contract}

\section{Performance Security}

\section{Bidding-Related Complaints}

43.1 Promptly after notification, the Employer shall send the successful Bidder the Contract Agreement.

43.2 Within 28 days of receipt of the Contract Agreement, the successful Bidder shall sign, date, and return it to the Employer.

44.1 Within 28 days of the receipt of notification of award through issuance of Letter of Acceptance from the Employer, the successful Bidder shall furnish the performance security in accordance with the Conditions of Contract, subject to ITB 36 and ITB 37, using for that purpose the Performance Security Form included in Section 9 (Contract Forms), or another form acceptable to the Employer. If the bank issuing performance security is located outside the Employer's country, it shall be counter-guaranteed or encashable by a bank in the Employer's country.

44.2 Failure of the successful Bidder to submit the abovementioned performance security or to sign the Contract Agreement shall constitute sufficient grounds for the annulment of the award and forfeiture of the bid security or execution of the Bid-Securing Declaration. In that event, the Employer may award the Contract to the next lowest evaluated Bidder whose offer is substantially responsive and is determined by the Employer to be qualified to perform the Contract satisfactorily.

44.3 The above provision shall also apply to the furnishing of a domestic preference security, if so required.

45.1 The procedures for dealing with Bidding-Related Complaints arising out of this bidding process are specified in the BDS. 


\section{Section 2: Bid Data Sheet}

This section consists of provisions that are specific to each procurement and supplement the information or requirements included in Section 1 (Instructions to Bidders).

\section{A. General}

\begin{tabular}{|l|l|}
\hline ITB 1.1 & The number of the Invitation for Bids (IFB) is: [insert name and IFB number] \\
\hline ITB 1.1 & The Employer is: [insert complete name of the Employer] \\
\hline ITB 1.1 & $\begin{array}{l}\text { The name of the bidding process is: [insert complete name] } \\
\text { The identification number of the bidding process is: [insert identification number] } \\
\text { The number and identification of lots comprising this bidding process is: } \\
\text { [ifthere are no lots, insert "None." If there are lots, insert a list of lots identifying each lot by number and title] }\end{array}$ \\
\hline ITB 2.1 & The Borrower is: [insert complete name of the Borrower] \\
\hline ITB 2.1 & The name of the Project is: [insert name of the project] \\
\hline
\end{tabular}

\section{B. Contents of Bidding Documents}

ITB 7.1

For clarification purposes only, the Employer's address is:

Attention: [insert full name of person, if applicable]

Street address: [insert street address and number]

Floor/Room number: [insert floor and room number, if applicable]

City: [insert name of city or town]

ZIP code: [insert postal (ZIP) code, if applicable]

Country: [insert name of country]

Telephone: [insert telephone number, including country and city codes]

Fax: [insert fax number, with country and city codes]

E-mail: [insert e-mail address, if applicable]

Requests for clarification should be received by the Employer no later than:

[insert no. of days, generally between 7 days to 21 days]. 
ITB 7.4

A Pre-Bid meeting [insert "shall" or "shall not"] take place.

[if a pre-bid meeting takes place, insert date, time, and place below]

Date:

Time:

Place:

A site visit conducted by the Employer [insert "will" or "will not be"] organized.

\section{Preparation of Bids}

\begin{tabular}{|c|c|}
\hline ITB 10.1 & The language of the Bid is: [insert "English"] \\
\hline ITB 11.1(b) & $\begin{array}{l}\text { In accordance with ITB } 12 \text { and ITB 14, the following schedules shall be submitted with } \\
\text { the Bid, including the priced Bill of Quantities for admeasurement contracts and Activity } \\
\text { Schedule for lump sum contracts: [insert schedules such as schedule of equipment, key personnel and } \\
\text { Subcontractors, and data on financial resources for meeting the required financial resources requirement that } \\
\text { must be submitted with the Bid together with the price schedules]. }\end{array}$ \\
\hline ITB 11.1(h) & $\begin{array}{l}\text { The Bidder shall submit with its Bid the following additional documents: [insert type of any } \\
\text { additional documents not already listed in ITB } 11.1 \text { that must be submitted with the Bid]. }\end{array}$ \\
\hline ITB 12.1 & $\begin{array}{l}\text { [Choose one of the following options as appropriate.] } \\
\text { [For admeasurement contracts:] } \\
\text { The units and rates in figures entered into the Bill of Quantities and Daywork Schedule } \\
\text { should be typewritten or if written by hand, must be in print form. Bill of Quantities and } \\
\text { Daywork Schedule not presented accordingly may be considered nonresponsive. } \\
\text { [or] } \\
\text { [For lump sum contracts: } \\
\text { The units and rates in figures entered into the Activity Schedule should be typewritten or if } \\
\text { written by hand, must be in print form. Activity Schedule not presented accordingly may be } \\
\text { considered nonresponsive. }\end{array}$ \\
\hline ITB 13.1 & Alternative Bids [insert "shall be" or "shall not be"] permitted. \\
\hline ITB 13.2 & $\begin{array}{l}\text { Alternative times for completion [insert "shall be" or "shall not be"] permitted. } \\
\text { If alternative times for completion are permitted, the evaluation method will be as specified } \\
\text { in Section } 3 \text { (Evaluation and Qualification Criteria). }\end{array}$ \\
\hline
\end{tabular}




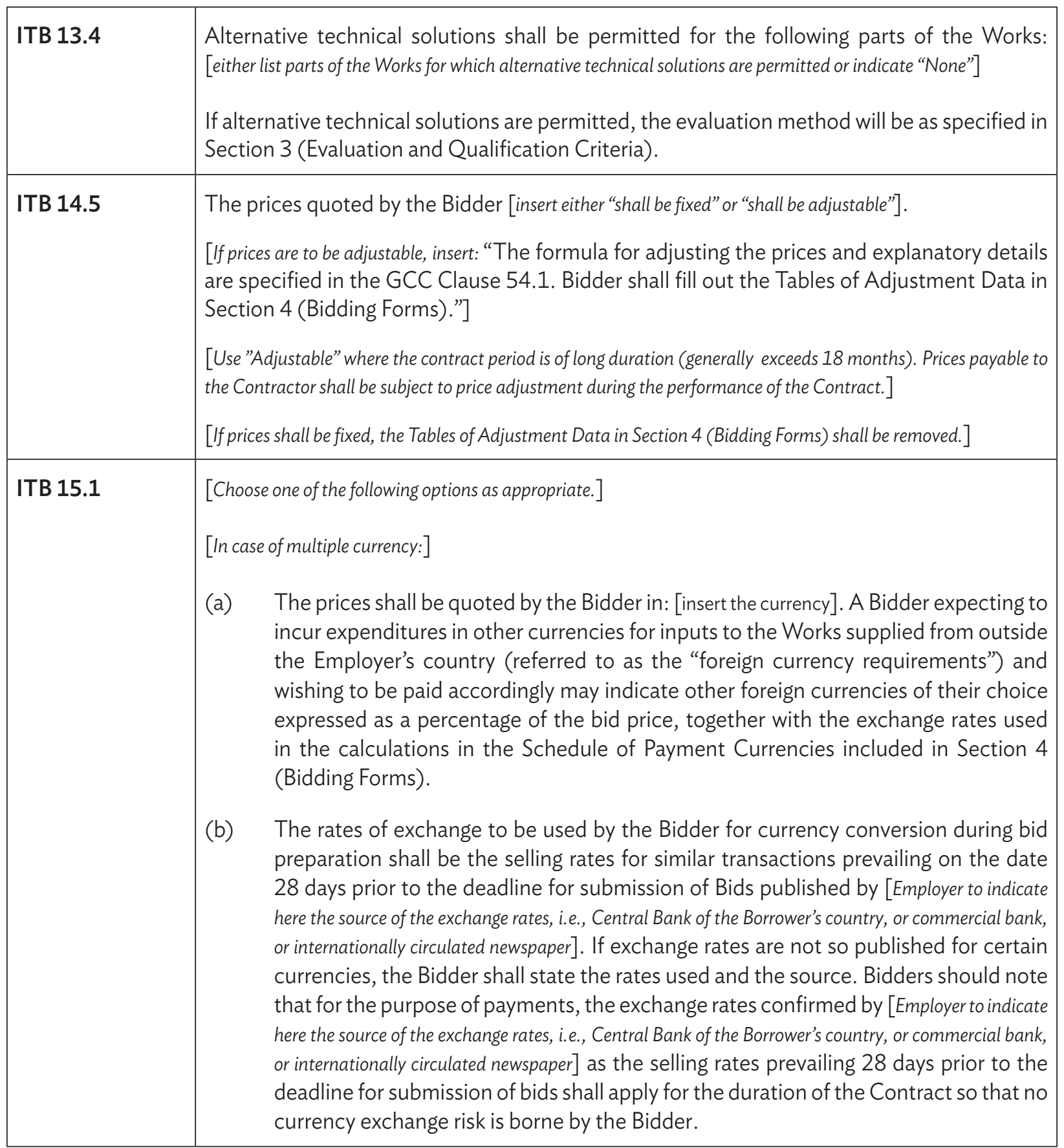


(c) Foreign currency requirements indicated by the Bidders in the Schedule of Payment Currencies shall include but not limited to the specific requirements for

- $\quad$ expatriate staff and labor employed directly on the Works;

- $\quad$ social, insurance, medical, and other charges relating to such expatriate staff and labor, and foreign travel expenses;

- imported materials, both temporary and permanent, including fuels, oil, and lubricants required for the Works;

- depreciation and usage of imported Plant and Contractor's Equipment, including spare parts, required for the Works;

- foreign insurance and freight charges for imported materials, Plant and Contractor's Equipment, including spare parts; and

- $\quad$ overhead expenses, fees, profit, and financial charges arising outside the Employer's country in connection with the Works.

(d) Bidders may be required by the Employer to clarify their foreign currency requirements, and to substantiate that the amounts included in the unit rates and prices and shown in the Schedule of Payment Currencies are reasonable and responsive to item (c) above, in which case a detailed breakdown of its foreign currency requirements shall be provided by the Bidder.

(e) Bidders should note that during the progress of the Works, the foreign currency requirements of the outstanding balance of the Contract Price may be adjusted by agreement between the Employer and the Contractor in order to reflect any changes in foreign currency requirements for the Contract, in accordance with Subclause 54.1 of the Conditions of Contract. Any such adjustment shall be effected by comparing the percentages quoted in the bid with the amounts already used in the Works and the Contractor's future needs for imported items.

$[$ or]

[In case of local currency:]

The prices shall be quoted by the Bidder and shall be paid in: [insert the local currency].

ITB 18.1

The bid validity period shall be [insert the number of days deemed appropriate] days.

[The period should be sufficient to permit completion of evaluation and comparison of bids, review of the recommended selection by the ADB (if so required), acquire all necessary approvals, and notify the successful Bidder of the award. Normally, the validity period should not exceed 120 days.]

ITB 19.1 [Choose one of the following options as appropriate.]

Neither a bid security nor a Bid-Securing Declaration is required.

[or]

The Bidder shall furnish a bid security in the amount of [insert amount and currency. The amount of the bid security should be stated as a fixed amount, normally computed as $1 \%$ to $2 \%$ of the estimated contract value.].

[or]

The Bidder shall furnish a Bid-Securing Declaration. 


\begin{tabular}{|c|c|}
\hline ITB 19.2 & The ineligibility period will be [insert number of years] \\
\hline ITB 19.4 & $\begin{array}{l}\text { [Choose one of the following options as appropriate.] } \\
\text { No further instruction. } \\
\text { [or] } \\
\text { Subject to the succeeding sentences, any bid not accompanied by an irrevocable and callable } \\
\text { bid security shall be rejected by the Employer as nonresponsive. If a Bidder submits a bid } \\
\text { security that (i) deviates in form, amount, and/or period of validity, or (ii) does not provide } \\
\text { sufficient identification of the Bidder (including, without limitation, failure to indicate the } \\
\text { name of the Joint Venture or, where the Joint Venture has not yet been constituted, the } \\
\text { names of all future Joint Venture Partners), the Employer shall request the Bidder to submit } \\
\text { a compliant bid security within [insert number of days; generally } 14 \text { days] days of receiving such a } \\
\text { request. Failure to provide a compliant bid security within the prescribed period of receiving } \\
\text { such a request shall cause the rejection of the Bid. } \\
\text { [or] } \\
\text { Subject to the succeeding sentences, any bid not accompanied by Bid-Securing Declaration } \\
\text { shall be rejected by the Employer as nonresponsive. If a Bidder submits a Bid-Securing } \\
\text { Declaration that (i) deviates in form, content, and/or period of validity or (ii) does not } \\
\text { provide sufficient identification of the Bidder (including, withoutlimitation, failure to indicate } \\
\text { the name of the Joint Venture or, where the Joint Venture has not yet been constituted, } \\
\text { the names of all future Joint Venture Partners), the Employer shall request the Bidder to } \\
\text { submit a compliant Bid-Securing Declaration within [insert number of days; generally } 7 \text { days] days } \\
\text { of receiving such a request. Failure to provide a compliant Bid-Securing Declaration within } \\
\text { the prescribed period of receiving such a request shall cause the rejection of the Bid. }\end{array}$ \\
\hline ITB 20.1 & In addition to the original Bid, the number of copies is: [insert number of copies required]. \\
\hline ITB 20.2 & $\begin{array}{l}\text { The written confirmation of authorization to sign on behalf of the Bidder shall consist of: } \\
\text { [insert the name and description of the documentation required to demonstrate the authority of the signatory } \\
\text { to sign the bid. Employer may wish to consider the following language: "An organizational document, board } \\
\text { resolution or its equivalent, or power of attorney specifying the representative's authority to sign the Bid on behalf } \\
\text { of, and to legally bind, the Bidder. If the Bidder is an intended or an existing Joint Venture, the power of attorney } \\
\text { should be signed by all partners and specify the authority of the named representative of the Joint Venture to sign } \\
\text { on behalf of, and legally bind, the intended or existing Joint Venture. If the Joint Venture has not yet been formed, } \\
\text { also include evidence from all proposed Joint Venture partners of their intent to enter into a Joint Venture in the } \\
\text { event of a contract award in accordance with ITB 11.2."] }\end{array}$ \\
\hline ITB 20.2 & $\begin{array}{l}\text { The Bidder shall submit an acceptable authorization within [insert number of days, generally } \\
14 \text { days] days. }\end{array}$ \\
\hline
\end{tabular}




\section{Submission and Opening of Bids}

\begin{tabular}{|c|c|}
\hline ITB 21.1 & $\begin{array}{l}\text { [Choose one of the following options as appropriate.] } \\
\text { Bidders shall submit their Bids by mail or by hand. } \\
{[\text { or }]} \\
\text { Bidders shall submit their Bids electronically. }\end{array}$ \\
\hline ITB 21.1(b) & $\begin{array}{l}\text { Electronic bidding submission procedures shall be: [insert a description of the electronic bidding } \\
\text { submission procedures if applied in accordance with ITB } 21.1 \text { above; otherwise, state "not applicable"]. }\end{array}$ \\
\hline ITB 22.1 & $\begin{array}{l}\text { For bid submission purposes only, the Employer's address is: } \\
\text { [insert all required and applicable information] } \\
\text { Attention: } \\
\text { Street address: } \\
\text { Floor/Room number: } \\
\text { City: } \\
\text { ZIP code: } \\
\text { Country: } \\
\text { The deadline for bid submission is: } \\
\text { Date: } \\
\text { Time: }\end{array}$ \\
\hline ITB 25.1 & $\begin{array}{l}\text { The bid opening shall take place at: [insert all required and applicable information] } \\
\text { Street address: } \\
\text { Floor/Room number: } \\
\text { City: } \\
\text { Country: } \\
\text { Date: } \\
\text { Time: }\end{array}$ \\
\hline ITB 25.1 & $\begin{array}{l}\text { Electronic bid opening procedure shall be as follows: [if electronic bidding is permitted in accordance } \\
\text { with ITB 21.1, insert here a description of the electronic bid opening procedures; otherwise, state "not applicable"] }\end{array}$ \\
\hline ITB 25.3 & $\begin{array}{l}\text { The Letter of Bid and Schedules shall be initialed by [insert number of initials] representatives of } \\
\text { the Employer attending the Bid opening. }\end{array}$ \\
\hline
\end{tabular}




\section{E. Evaluation and Comparison of Bids}

\begin{tabular}{|c|c|}
\hline ITB 32.1 & $\begin{array}{l}\text { [Pursuant to ITB 15.1, choose one of the following options as appropriate.] } \\
\text { [In case of multiple currency] } \\
\text { The currency that shall be used for bid evaluation and comparison purposes to convert all bic } \\
\text { prices expressed in various currencies into a single currency is: [insert the name of the currency] } \\
\text { The source of the selling exchange rate shall be: [insert the name of the source of the exchange rates, } \\
\text { which should be the Central Bank in the Employer's country or specify another institution that carries out the } \\
\text { function of a Central Bank]. } \\
\text { The date for the selling exchange rate shall be: [specify any date (day/month/year) not earlier thar } \\
28 \text { days prior to the deadline for submission of the bids or later than the original date for the expiry of bid validity, } \\
\text { which may, for example, be the date of the deadline for submission of bids]. } \\
\text { [or] } \\
\text { [In case of local currency] } \\
\text { Not applicable. }\end{array}$ \\
\hline ITB 33.1 & $\begin{array}{l}\text { Domestic preference [insert "shall" or "shall not"] apply. } \\
\text { [If domestic preference applies, insert "The application methodology shall be as stipulated in } \\
\text { Section } 3 \text { (Evaluation and Qualification Criteria)".] }\end{array}$ \\
\hline ITB 34.1 & $\begin{array}{l}\text { The Employer [insert "intends" or "does not intend"] for the contractor to execute any specific } \\
\text { elements of the Works through nominated Subcontractors. }\end{array}$ \\
\hline
\end{tabular}




\begin{tabular}{|c|c|}
\hline ITB 38.2 & $\begin{array}{l}\text { [Choose one of the following options as appropriate.] } \\
\text { The qualifications of other firms such as the Bidder's subsidiaries, parent entities, or affiliates shall } \\
\text { not be permitted. } \\
\text { [or] } \\
\text { The qualifications of other firms such as the Bidder's subsidiaries, parent entities, or affiliates } \\
\text { shall be permitted for criteria } 2.3 \text { Financial Situation in Section 3. The other firms must satisfy the } \\
\text { criteria stated in } 2.1 \text { Eligibility in Section 3. } \\
\text { [or] } \\
\text { The qualifications of other firms such as the Bidder's subsidiaries, parent entities, or affiliates shall } \\
\text { be permitted for criterion } 2.4 .1 \text { Contracts of Similar Size and Nature and/or } 2.4 .2 \text { Construction } \\
\text { Experience in Key Activities in Section 3. The other firms must satisfy the criteria stated in } 2.1 \\
\text { Eligibility in Section } 3 \text {. } \\
\text { [or] } \\
\text { The qualifications of other firms such as the Bidder's subsidiaries, parent entities, or affiliates shall } \\
\text { be permitted for criteria } 2.3 \text { Financial Situation and } 2.4 .1 \text { Contracts of Similar Size and Nature } \\
\text { and/or } 2.4 .2 \text { Construction Experience in Key Activities in Section 3. The other firms must satisfy } \\
\text { the criteria stated in } 2.1 \text { Eligibility in Section } 3 \text {. } \\
\text { [If permitted, add "The Bidder shall provide the Affiliate Company Guarantee Form included in } \\
\text { Section } 4 \text { (Bidding Forms) filled out and signed by for each subsidiary, parent entity, or affiliate } \\
\text { that the Bidder submits for consideration of the Employer in determining its qualifications."] }\end{array}$ \\
\hline
\end{tabular}




\begin{tabular}{|l|l|}
\hline ITB 40.1 & $\begin{array}{l}\text { [Choose one of the following options as appropriate.] } \\
\text { Standstill provisions shall not apply. } \\
{[\text { or }]} \\
\text { Standstill provisions shall apply. The duration of standstill period will be [insert number of days] } \\
\text { days from the date of notice of intention for award of contract. } \\
\text { The Employer shall, at the start of the standstill period, notify in writing each Bidder that } \\
\text { submitted a bid, of its intention to award a contract to the successful bidder at the end of } \\
\text { standstill period. The notification using the form included in Section } 9 \text { (Contract Forms) } \\
\text { shall include the following information: } \\
\text { (a) the name of each Bidder who submitted a Bid; } \\
\text { (b) the bid prices as read out at bid opening; } \\
\text { (c) the name and evaluated prices of each Bid that was evaluated; } \\
\text { (d) the name of Bidders whose bids were rejected and the reasons for their rejection; } \\
\text { (e) the name of the winning Bidder, and the price it offered, as well as the duration and } \\
\text { (f) a statement of the reason(s) the bid of the unsuccessful Bidder to whom the notification } \\
\text { is addressed was unsuccessful, unless the price information under (e) of this paragraph } \\
\text { already reveals the reason. }\end{array}$ \\
\hline
\end{tabular}

\section{F. Award of Contract}

ITB 45.1 The procedures for Bidding-Related Complaints are referenced in the Procurement Regulations for ADB Borrowers (Appendix 7). The Bidder should submit its complaint following these procedures, in writing, to:

For the attention: [insert full name of person receiving complaints]

Title/position: [insert title/position]

Employer: [insert name of Employer]

E-mail address: [insert e-mail address]

Fax number: [insert fax number, delete if not used] 


\section{Section 3: Evaluation and Qualification Criteria}

\section{NOTE}

This section contains the criteria that the Employer shall use to evaluate bids and qualify Bidders if the bidding was not preceded by a prequalification exercise and postqualification is applied. ADB requires Bidders to be qualified by meeting predefined, precise minimum requirements. The method entails setting criteria, which, if not met by the Bidder, results in disqualification. It will therefore be necessary to ensure that a Bidder's risk of having its bid rejected on grounds of qualification is remote if due diligence is exercised by the Bidder during bid preparation. For that purpose, clear-cut, pass-fail qualification criteria need to be defined and indicated in the Invitation for Bids and the Bidding Document to enable Bidders to make an informed decision whether to pursue a specific contract and, if so, whether to pursue it as a single entity or in Joint Venture. The criteria adopted must relate to characteristics that are essential to ensure satisfactory execution of the contract, and must be stated in clear terms. In accordance with ITB 35 to ITB 38, no other methods, criteria and factors shall be used. The Bidder shall provide all the information requested in the forms included in Section 4 (Bidding Forms).

\section{Table of Criteria}

1. Evaluation

1.1 Adequacy of Technical Proposal...

1.2 Completion Time

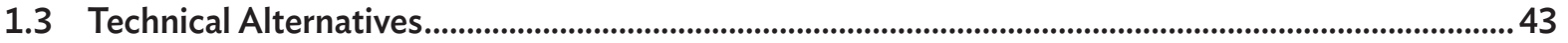

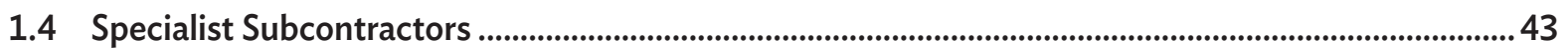

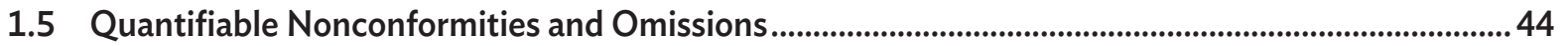

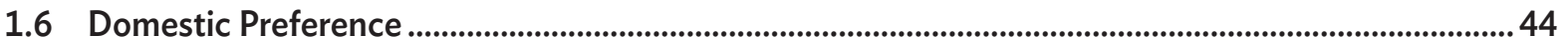

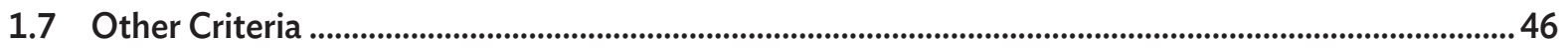

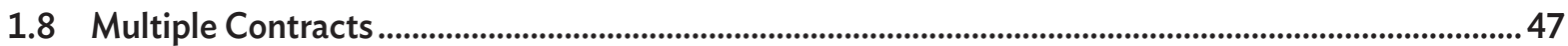

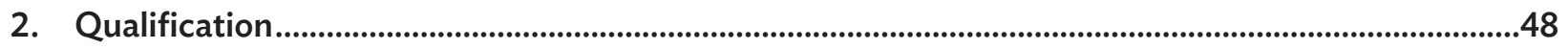

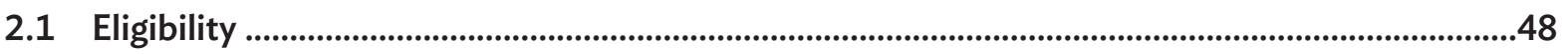

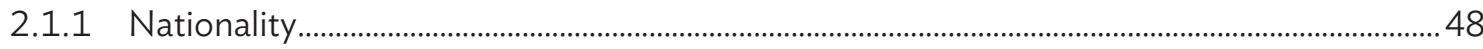

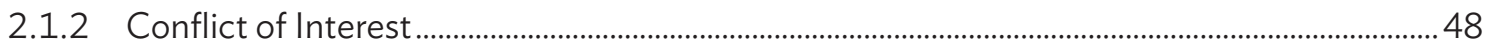

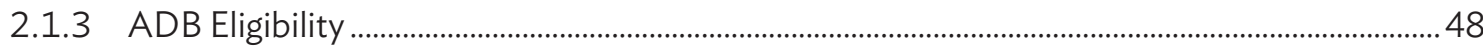




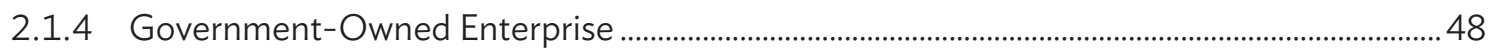

2.1.5 United Nations Eligibility .................................................................................................................... 48

2.2 Historical Contract Nonperformance ............................................................................................49

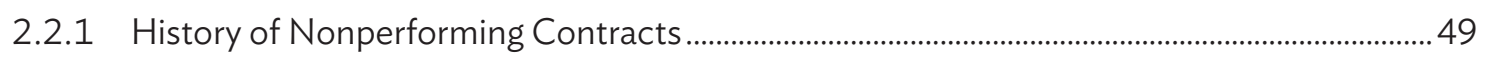

2.2.2 Suspension Based on Execution of Bid-Securing Declaration .................................................. 49

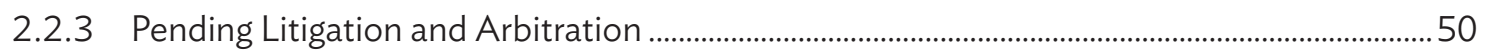

2.2.4 Declaration: Environmental, Health and Safety Past Performance.........................................50

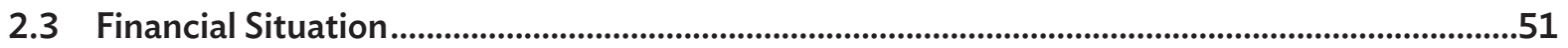

2.3.1 Historical Financial Performance ........................................................................................................... 51

2.3.2 Average Annual Construction Turnover ..................................................................................... 51

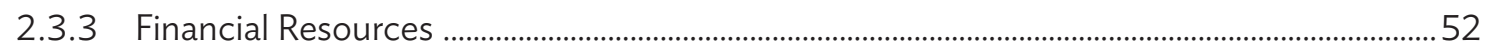

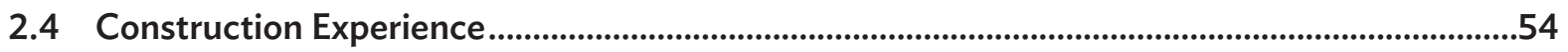

2.4.1 Contracts of Similar Size and Nature ...............................................................................................54

2.4.2 Construction Experience in Key Activities .....................................................................................56

2.4.3 Specific Experience in Managing Environmental, Health and Safety Aspects.......................57

2.5 Organizational Environmental, Health and Safety System ..........................................................58

2.5.1 Environmental, Health and Safety Certification ............................................................................58

2.5.2 Environmental, Health and Safety Documentation ……………………...................................59

2.5.3 Environmental, Health and Safety Dedicated Personnel ............................................................59 


\section{Evaluation}

In addition to the criteria listed in ITB 35.2 (a)-(f), other relevant factors are as follows:

NOTE The Employer shall include only the applicable criteria from those listed below.

\subsection{Adequacy of Technical Proposal}

Evaluation of the Bidder's Technical Proposal will include an assessment of the Bidder's technical capacity to successfully implement the contract considering its proposed site organization, method statement, mobilization, and construction schedule (to be described by the Bidder in sufficient detail to demonstrate the adequacy of its work methods, scheduling, and material sourcing) including the extent to which they are presented in a consistent manner and comply with requirements stipulated in Section 6 (Employer's Requirements) without material deviation, reservation, or omission.

Noncompliance with equipment and personnel requirements described in Section 6 (Employer's Requirements) shall not normally be a ground for bid rejection, and such noncompliance will be subject to clarification during bid evaluation and rectification prior to contract award.

\section{NOTE}

The Employer shall refer to the appropriate forms in Section 4 to be filled out, if provided. The Employer shall assess whether proposed site organization, method statement, mobilization, and construction schedule described in Section 4 (Bidding Forms) are presented in consistent manner and comply with requirements stipulated in Section 6 (Employer's Requirements) without material deviation, reservation, or omission.

\subsection{Completion Time}

An alternative Completion Time, if permitted under ITB 13.2, will be evaluated as follows:

\section{NOTE The Employer shall describe how this factor will be evaluated.}

\subsection{Technical Alternatives}

Technical alternatives, if permitted under ITB 13.4, will be evaluated as follows:

\section{NOTE The Employer shall describe how this factor will be evaluated.}

\subsection{Specialist Subcontractors}

Only the specific experience of Specialist Subcontractors for key activities specified in criterion 2.4.2 Construction Experience in Key Activities will be considered. The experience of Specialist Subcontractors in contracts of similar size and nature, and their financial resources shall not be added to those of the Bidder for purposes of qualification of the Bidder. 


\subsection{Quantifiable Nonconformities and Omissions}

Subject to ITB 14.2 and ITB 35.2, the evaluated cost of quantifiable nonconformities including omissions, is determined as follows:

[Insert in bidding document: "Pursuant to ITB 30.3, the cost of all quantifiable nonmaterial nonconformities shall be evaluated, including omissions in Daywork where competitively priced but excluding omission of prices in the Bill of Quantities. The Employer will make its own assessment of the cost of any nonmaterial nonconformities and omissions for the purpose of ensuring fair comparison of bids."]

\section{NOTE}

The cost of minor omissions or missing items should be added to the bid price to allow for bid comparison on an equal basis. Omissions in Daywork, if priced competitively, are covered by the price adjustment as provided in ITB 35.2(a), but missing unit prices for items in the Bill of Quantities are excluded as provided in ITB 14.2. The price adjustment should be based on a reasonable estimate of the cost by the executing agency, engineer, consultant, or bid evaluation committee, taking into consideration the corresponding quoted prices from other conforming bids. The price adjustment should be based on the fair price of the omitted item. The most frequently used method is to use the price equal to the highest price quoted for the same item by the other responsive Bidders.

\subsection{Domestic Preference}

1.6.1 In comparing domestic bids with foreign bids, domestic preference will be granted to eligible domestic contractors, as defined below, in accordance with the following provisions:

(a) For application of domestic preference, all responsive bids will first be classified into the following two Groups:

(i) Group A: bids offered by Domestic Contractors and Joint Ventures eligible for the preference in accordance with the criteria described below; and

(ii) Group B: bids offered by other Contractors.

(b) The lowest evaluated Bid of each group will then be determined by comparing all evaluated Bids in each group among themselves.

(c) Such lowest evaluated Bids will next be compared with each other and if, as a result of this comparison, a Bid from Group A is found to be the lowest, it will be selected for the award of contract.

(d) If, however, as a result of the comparison under (c) above, the lowest Bid is found to be from Group B, it will be further compared with the lowest evaluated Bid from Group A. For the purpose of this further comparison only an upward adjustment will be made to the lowest evaluated bid price of Group B by adding an amount equal to [insert a percentage not exceeding 7.5\%] of the bid price. If, after such comparison, the Group A bid is determined to be the lowest, it will be selected for the award of contract; if not, the lowest evaluated Bid from Group B will be selected. 
1.6.2 Domestic Contractors and Joint Venture firms must meet the following minimum criteria for eligibility under the domestic preference scheme.

(i) Domestic Contractors

- $\quad$ are incorporated or established under the laws of the Borrower's country,

- have majority ownership by nationals of the Borrower, and

- will not subcontract more than $50 \%$ of the total value of the work to foreign contractors.

(ii) A Joint Venture between a Domestic Contractor and its foreign partner is eligible for the preference only if

- the Domestic Partner(s) is individually eligible for the preference according to the criteria stated in 1.6.2(i);

- the Domestic Partner(s) would not qualify for the work on technical or financial grounds without the foreign participation; and

- the Domestic Partner(s), under the arrangements proposed, carry out at least $50 \%$ of the value of the work.

1.6.3 Contractors applying for the preference provide information with their bids, including details of ownership. This is to determine if, under the applicable criteria, a particular firm or group of firms qualifies for the preference.

1.6.4 If the Contract is awarded to a Bidder who has received the preference pursuant to the foregoing provisions, such Contractor shall not subcontract to foreign contractors more than $50 \%$ of the total value of their work.

1.6.5 A Joint Venture that is awarded the Contract as a result of the application of the above domestic preference provisions, shall furnish the Employer, together with the performance security, a "domestic preference security" to guarantee that the profit and loss distribution and work-sharing arrangements with which the Joint Venture satisfied the criteria of Subclause 1.6.2 (ii) will not be modified throughout the execution of the Contract. The domestic preference security shall be in the form of an unconditional on-demand bank guarantee or standby letter of credit acceptable to the Employer, for an amount in a convertible currency equivalent to the difference between the Joint Venture's bid price and the bid price of the lowest foreign bid. The domestic preference security shall be issued either (a) by a bank located in the country of the Employer, or (b) directly by a foreign bank acceptable to the Employer. The domestic preference security shall be valid until the Contractor has substantially completed the Works and a Certificate of Completion of the Works has been issued by the Project Manager in accordance with the provisions of GCC 69, and such security shall be returned to the Contractor together with the Certificate of Completion of the Works. 


\subsection{Other Criteria}

Add any other relevant criteria to consider in bid evaluation, such as quality, responsiveness to socio-economic or environmental objectives, sustainable procurement technical requirements that have been specified in Section 6, special security considerations at site, and Bidder's record of achieving the desired results based on experience and performance history. For each criteria, clearly specify the evaluation methodology, e.g. (i) any relevant requirement specified in Section 6 will be evaluated on a pass/fail (compliance basis), (ii) in addition to evaluating that requirement on a pass/fail (compliance basis), if applicable, specify the monetary adjustments to be applied to bid prices for comparison purposes on account of bids that exceed the specified minimum requirements, or (iii) if merit point scoring is applied in the evaluation, the criteria will be one of the technical factors.

\subsubsection{Environmental, Health and Safety Management Plan (EHSMP)}

[The following are sample criteria]

Any bid not accompanied by the EHSMP may be rejected by the Employer as nonresponsive. If a Bidder submits a EHSMP that is not commensurate with the risks and impacts of the proposed works and activities in the bidding document, the Employer shall issue a request for clarification to request for further information from the Bidder. The Bidder must submit the requested information within [insert number of days, normally 5 working days] days of receiving such a request. Failure to provide a satisfactory response to the request for further information within the prescribed period of receiving such a request may cause the rejection of the Bid.

\section{NOTE}

The Employer should evaluate the responsiveness of the EHSMP to the requirements of the project Environmental Management Plan and other supplementary reference in Section 6, the Employer's country-specific requirement and local regulations on environmental, health and safety, and/or international good practices and outline here as the basis of evaluation. EA should seek support from the Engineer/PMC/H\&S consultant in reviewing the plan if they do not have in-house expertise.

\subsubsection{Sustainable Procurement}

Example text: The following sustainable procurement technical requirements will be evaluated on a pass/fail basis. Failure to meet any of the following requirements will result in mandatory rejection of the bid.

[E.g. No diesel plant is proposed for the construction process.]

\section{NOTE}

If specific sustainable procurement technical requirements have been specified in Section 6 (Employer's Requirements), either state that (i) those requirements will be evaluated on a pass/fail (compliance basis) or otherwise (ii) in addition to evaluating those requirements on a pass/fail (compliance basis), if applicable, specify the monetary adjustments to be applied to Bid prices for comparison purposes on account of Bids that exceed the specified minimum sustainable procurement technical requirements. 


\subsubsection{Life Cycle costs (for Financial Evaluation)}

[State either life cycle costing "shall" or "shall not apply". If life cycle costing applies for Bid evaluation, the methodology and the information expected from Bidders shall be specified]

The factors for calculation of the life cycle cost are

(i) number of years for life cycle: [Insert number of years],

(ii) operating costs [state how they will be determined],

(iii) maintenance costs, including the cost of spare parts for the initial period of operation [state how they will be determined], and

(iv) Discount rate: [insert discount rate in percent] to be used to discount to present value all annual future costs calculated under (ii) and (iii) above for the period specified in (i).

\section{NOTE}

Life cycle costing should be used when the costs of operation and/or maintenance over the specified life of the Works are estimated to be considerable in comparison with the initial cost and may vary among different Bids. It shall be evaluated on a net present value basis. If life cycle costing is to be applied for Bid evaluation, the Employer shall specify the relevant information on its application here.

If Life Cycle Costs is applied, corresponding cost items for operating and maintenance costs should be added to Section 4 Letter of Bid, Bill of Quantity.

\subsection{Multiple Contracts}

If works are grouped in multiple contracts and pursuant to ITB 35.4, the Employer shall evaluate and compare Bids on the basis of a contract, or a combination of contracts, or as a total of contracts in order to arrive at the least-cost combination for the Employer by taking into account discounts offered by Bidders in case of award of multiple contracts.

If a Bidder as defined in ITB 4.1 submits several successful (lowest evaluated substantially responsive) bids, the evaluation will also include an assessment of the Bidder's capacity to meet the following aggregated requirements as presented in the bid:

- Average annual construction turnover,

- Financial resources,

- Equipment to be allocated, and

- Personnel to be fielded.

\section{NOTE}

The Employer shall refer to the applicable qualification requirement(s) for each contract in Part 2 of this section. 


\section{Qualification}

\subsection{Eligibility}

\begin{tabular}{|c|c|c|c|c|c|}
\hline Criteria & \multicolumn{4}{|c|}{ Compliance Requirements } & Documents \\
\hline & & \multicolumn{3}{|c|}{ Joint Venture } & \\
\hline Requirement & Single Entity & $\begin{array}{c}\text { All Partners } \\
\text { Combined }\end{array}$ & $\begin{array}{l}\text { Each } \\
\text { Partner }\end{array}$ & $\begin{array}{l}\text { One } \\
\text { Partner }\end{array}$ & $\begin{array}{l}\text { Submission } \\
\text { Requirements }\end{array}$ \\
\hline
\end{tabular}

\subsubsection{Nationality}

\begin{tabular}{l|c|c|c|c|c}
$\begin{array}{l}\text { Nationality in accordance with } \\
\text { ITB 4.2. }\end{array}$ & $\begin{array}{c}\text { Must meet } \\
\text { requirement }\end{array}$ & $\begin{array}{c}\text { Must meet } \\
\text { requirement }\end{array}$ & $\begin{array}{c}\text { Must meet } \\
\text { requirement }\end{array}$ & $\begin{array}{c}\text { Not } \\
\text { applicable }\end{array}$ & $\begin{array}{c}\text { Forms } \\
\text { ELI }-1 ; \text { ELI - 2 } \\
\text { with attachments }\end{array}$ \\
\hline
\end{tabular}

\subsubsection{Conflict of Interest}

No conflicts of interest in accordance with ITB 4.3.

\begin{tabular}{|c|c|c|c|c|}
$\begin{array}{c}\text { Must meet } \\
\text { requirement }\end{array}$ & $\begin{array}{c}\text { Must meet } \\
\text { requirement }\end{array}$ & $\begin{array}{c}\text { Must meet } \\
\text { requirement }\end{array}$ & $\begin{array}{c}\text { Not } \\
\text { applicable }\end{array}$ & Letter of Bid \\
\hline
\end{tabular}

\subsubsection{ADB Eligibility}

Not having been declared ineligible

by ADB, as described in ITB 4.4 .

\begin{tabular}{|c|c|c|c|c|}
$\begin{array}{c}\text { Must meet } \\
\text { requirement }\end{array}$ & $\begin{array}{c}\text { Must meet } \\
\text { requirement }\end{array}$ & $\begin{array}{c}\text { Must meet } \\
\text { requirement }\end{array}$ & $\begin{array}{c}\text { Not } \\
\text { applicable }\end{array}$ & Letter of Bid \\
\hline
\end{tabular}

\subsubsection{Government-Owned Enterprise}

\begin{tabular}{|l|c|c|c|c|c|}
\hline $\begin{array}{l}\text { Bidder required to meet conditions } \\
\text { of ITB 4.5. }\end{array}$ & $\begin{array}{c}\text { Must meet } \\
\text { requirement }\end{array}$ & $\begin{array}{c}\text { Must meet } \\
\text { requirement }\end{array}$ & $\begin{array}{c}\text { Must meet } \\
\text { requirement }\end{array}$ & $\begin{array}{c}\text { Not } \\
\text { applicable }\end{array}$ & $\begin{array}{c}\text { Forms } \\
\text { ELI }-1 ; \text { ELI }-2 \\
\text { with attachments }\end{array}$ \\
\hline
\end{tabular}

\subsubsection{United Nations Eligibility}

\begin{tabular}{|l|c|c|c|c|c|}
\hline $\begin{array}{l}\text { Not having been excluded by an act } \\
\text { of compliance with a United Nations } \\
\text { Security Council resolution in } \\
\text { accordance with ITB 4.8. }\end{array}$ & $\begin{array}{c}\text { Must meet } \\
\text { requirement }\end{array}$ & $\begin{array}{c}\text { Must meet } \\
\text { requirement }\end{array}$ & $\begin{array}{c}\text { Must meet } \\
\text { requirement }\end{array}$ & $\begin{array}{c}\text { Not } \\
\text { applicable }\end{array}$ & Letter of Bid \\
\hline
\end{tabular}

\section{NOTE}

It is the obligation of the Employer to confirm an entity's eligibility by checking ADB's complete Sanctions List (for all bidders) at various stages of bidding process including bid evaluation, prior to contract award, as well as during processing of contract variations, extensions or modifications. ADB has the right to monitor the Employer's compliance to this obligation.

ADB's Complete Sanctions List and the guide on how to get its access are available at https://www.adb.org/who-we-are/integrity/sanctions. 


\subsection{Historical Contract Nonperformance}

\subsubsection{History of Nonperforming Contracts}

\begin{tabular}{|c|c|c|c|c|c|}
\hline Criteria & \multicolumn{4}{|c|}{ Compliance Requirements } & Documents \\
\hline \multirow[b]{2}{*}{ Requirement } & \multirow[b]{2}{*}{ Single Entity } & \multicolumn{3}{|c|}{ Joint Venture } & \multirow[b]{2}{*}{$\begin{array}{l}\text { Submission } \\
\text { Requirements }\end{array}$} \\
\hline & & $\begin{array}{c}\text { All Partners } \\
\text { Combined }\end{array}$ & $\begin{array}{c}\text { Each } \\
\text { Partner }\end{array}$ & $\begin{array}{c}\text { One } \\
\text { Partner }\end{array}$ & \\
\hline $\begin{array}{l}\text { Nonperformance of a contract } \\
\text { did not occur as a result of } \\
\text { contractor default since } \\
1 \text { January [insert year]. }\end{array}$ & $\begin{array}{l}\text { Must meet } \\
\text { requirement }\end{array}$ & $\begin{array}{l}\text { Must meet } \\
\text { requirements }\end{array}$ & $\begin{array}{l}\text { Must meet } \\
\text { requirement }^{\mathrm{b}}\end{array}$ & $\begin{array}{c}\text { Not } \\
\text { applicable }\end{array}$ & Form CON-1 \\
\hline
\end{tabular}

a Nonperformance, as decided by the Employer, shall include all contracts where (a) nonperformance was not challenged by the contractor, including through referral to the dispute resolution mechanism under the respective contract, and (b) contracts that were so challenged but fully settled against the contractor. Nonperformance shall not include contracts where Employers decision was overruled by the dispute resolution mechanism. Nonperformance must be based on all information on fully settled disputes or litigation, i.e. dispute or litigation that has been resolved in accordance with the dispute resolution mechanism under the respective contract and where all appeal instances available to the Bidder have been exhausted.

b This requirement also applies to contracts executed by the Bidder as Joint Venture partner.

\subsubsection{Suspension Based on Execution of Bid-Securing Declaration}

\begin{tabular}{|c|c|c|c|c|c|}
\hline Criteria & \multicolumn{4}{|c|}{ Compliance Requirements } & Documents \\
\hline \multirow[b]{2}{*}{ Requirement } & \multirow[b]{2}{*}{ Single Entity } & \multicolumn{3}{|c|}{ Joint Venture } & \multirow[b]{2}{*}{$\begin{array}{l}\text { Submission } \\
\text { Requirements }\end{array}$} \\
\hline & & $\begin{array}{l}\text { All Partners } \\
\text { Combined }\end{array}$ & $\begin{array}{l}\text { Each } \\
\text { Partner }\end{array}$ & $\begin{array}{l}\text { One } \\
\text { Partner }\end{array}$ & \\
\hline $\begin{array}{l}\text { Not under suspension based } \\
\text { on execution of a Bid-Securing } \\
\text { Declaration pursuant to ITB } 4.6 \text {. }\end{array}$ & $\begin{array}{l}\text { Must meet } \\
\text { requirement }\end{array}$ & $\begin{array}{l}\text { Must meet } \\
\text { requirement }\end{array}$ & $\begin{array}{l}\text { Must meet } \\
\text { requirement }\end{array}$ & $\begin{array}{l}\text { Not } \\
\text { applicable }\end{array}$ & Letter of Bid \\
\hline
\end{tabular}




\subsubsection{Pending Litigation and Arbitration}

Pending litigation and arbitration criterion [shall/shall not] apply. ${ }^{a}$

\begin{tabular}{|c|c|c|c|c|c|}
\hline Criteria & \multicolumn{4}{|c|}{ Compliance Requirements } & Documents \\
\hline \multirow[b]{2}{*}{ Requirement } & \multirow[b]{2}{*}{ Single Entity } & \multicolumn{3}{|c|}{ Joint Venture } & \multirow[b]{2}{*}{$\begin{array}{l}\text { Submission } \\
\text { Requirements }\end{array}$} \\
\hline & & $\begin{array}{c}\text { All Partners } \\
\text { Combined }\end{array}$ & $\begin{array}{c}\text { Each } \\
\text { Partner }\end{array}$ & $\begin{array}{c}\text { One } \\
\text { Partner }\end{array}$ & \\
\hline $\begin{array}{l}\text { All pending litigation, arbitration } \\
\text { or other material events } \\
\text { impacting the net worth and/or } \\
\text { liquidity of the bidder, if any, shall } \\
\text { be treated as resolved against the } \\
\text { Bidder and so shall in total not } \\
\text { represent more than ........... } \\
\ldots . . \text { b percent of the Bidder's net }^{\text {worth calculated as the difference }} \\
\text { between total assets and total } \\
\text { liabilities. }\end{array}$ & $\begin{array}{l}\text { Must meet } \\
\text { requirement }\end{array}$ & $\begin{array}{c}\text { Not } \\
\text { applicable }\end{array}$ & $\begin{array}{l}\text { Must meet } \\
\text { requirement }\end{array}$ & $\begin{array}{c}\text { Not } \\
\text { applicable }\end{array}$ & Form CON - 1 \\
\hline
\end{tabular}

a The Employer may choose whether to apply or not to apply this criterion:

1 If the Employer chooses to apply this criterion, it should indicate "shall apply" and use the table in 2.2.3, or

2 If the Employer chooses not to apply this criterion, it should indicate "shall not apply" and delete the table in 2.2.3.

b If the criterion is applied, the Employer should indicate a percentage within the range of $50 \%-100 \%$ of a Bidder's net worth.

\subsubsection{Declaration: Environmental, Health and Safety Past Performance}

\begin{tabular}{|c|c|c|c|c|c|}
\hline Criteria & \multicolumn{4}{|c|}{ Compliance Requirements } & Documents \\
\hline \multirow[b]{2}{*}{ Requirement } & \multirow[b]{2}{*}{ Single Entity } & \multicolumn{3}{|c|}{ Joint Venture } & \multirow[b]{2}{*}{$\begin{array}{c}\text { Submission } \\
\text { Requirements }\end{array}$} \\
\hline & & $\begin{array}{c}\text { All Partners } \\
\text { Combined }\end{array}$ & $\begin{array}{c}\text { Each } \\
\text { Partner }\end{array}$ & $\begin{array}{c}\text { One } \\
\text { Partner }\end{array}$ & \\
\hline $\begin{array}{l}\text { Declare any contracts } \\
\text { that have been suspended } \\
\text { or terminated and/or } \\
\text { performance security called } \\
\text { by an employer for reasons } \\
\text { related to the non-compliance } \\
\text { of any environmental, health } \\
\text { and safety contractual } \\
\text { obligations in the past } \\
\text { five years. }\end{array}$ & $\begin{array}{l}\text { Must make the } \\
\text { declaration. If the } \\
\text { bidder proposes } \\
\text { Specialist Sub- } \\
\text { contractor/s to } \\
\text { meet EQC 2.4.2, } \\
\text { those Specialist } \\
\text { Sub-contractor/s } \\
\text { must also make } \\
\text { the declaration }\end{array}$ & $\begin{array}{c}\text { Not } \\
\text { applicable }\end{array}$ & $\begin{array}{l}\text { Each partner } \\
\text { must make the } \\
\text { declaration. If the } \\
\text { bidder proposes } \\
\text { Specialist Sub- } \\
\text { contractor/s to } \\
\text { meet EQC } 2.4 .2 \\
\text { those Specialist } \\
\text { Sub-contractor/s } \\
\text { must also make } \\
\text { the declaration. }\end{array}$ & $\begin{array}{c}\text { Not } \\
\text { applicable }\end{array}$ & Form CON-2 \\
\hline
\end{tabular}

a The Employer may use this information to seek further information or clarifications regarding corrective actions undertaken by the contractor during the bidding stage and the associated due diligence. 


\subsection{Financial Situation}

\subsubsection{Historical Financial Performance}

\begin{tabular}{|c|c|c|c|c|c|}
\hline Criteria & \multicolumn{4}{|c|}{ Compliance Requirements } & Documents \\
\hline \multirow[b]{2}{*}{ Requirement } & \multirow[b]{2}{*}{ Single Entity } & \multicolumn{3}{|c|}{ Joint Venture } & \multirow[b]{2}{*}{$\begin{array}{l}\text { Submission } \\
\text { Requirements }\end{array}$} \\
\hline & & $\begin{array}{c}\text { All } \\
\text { Partners } \\
\text { Combined }\end{array}$ & $\begin{array}{c}\text { Each } \\
\text { Partner }\end{array}$ & $\begin{array}{c}\text { One } \\
\text { Partner }\end{array}$ & \\
\hline $\begin{array}{l}\text { Submission of audited financial } \\
\text { statements or, if not required by the law } \\
\text { of the Bidder's country, other financial } \\
\text { statements acceptable to the Employer, } \\
\text { for the last ........... years to } \\
\text { demonstrate the current soundness } \\
\text { of the Bidder's financial position. As a } \\
\text { minimum, the Bidder's net worth for the } \\
\text { last year calculated as the difference } \\
\text { between total assets and total liabilities } \\
\text { should be positive. }\end{array}$ & $\begin{array}{l}\text { Must meet } \\
\text { requirement }\end{array}$ & $\begin{array}{c}\text { Not } \\
\text { applicable }\end{array}$ & $\begin{array}{l}\text { Must meet } \\
\text { requirement }\end{array}$ & $\begin{array}{c}\text { Not } \\
\text { applicable }\end{array}$ & $\begin{array}{c}\text { Form FIN - } 1 \\
\text { with } \\
\text { attachments }\end{array}$ \\
\hline
\end{tabular}

a Indicate time period between 3 and 5 years.

\section{NOTE}

The financial information provided by the Bidder should be reviewed in its entirety to allow a truly informed judgment, and the pass-fail decision on the financial position of the Bidder should be given on this basis. Any abnormal features that may lead to financial problems should alert the Employer to seek expert professional advice for further review and interpretation.

\subsubsection{Average Annual Construction Turnover}

\begin{tabular}{|c|c|c|c|c|c|}
\hline Criteria & \multicolumn{4}{|c|}{ Compliance Requirements } & Documents \\
\hline \multirow[b]{2}{*}{ Requirement } & \multirow[b]{2}{*}{ Single Entity } & \multicolumn{3}{|c|}{ Joint Venture } & \multirow[b]{2}{*}{$\begin{array}{l}\text { Submission } \\
\text { Requirements }\end{array}$} \\
\hline & & $\begin{array}{c}\text { All Partners } \\
\text { Combined }\end{array}$ & $\begin{array}{c}\text { Each } \\
\text { Partner }\end{array}$ & $\begin{array}{c}\text { One } \\
\text { Partner }\end{array}$ & \\
\hline $\begin{array}{l}\text { Minimum average annual } \\
\text { construction turnover of } \$ \ldots \text { a } \\
\text { calculated as total certified } \\
\text { payments received for contracts in } \\
\text { progress or completed, within the } \\
\text { last....... years. }\end{array}$ & $\begin{array}{l}\text { Must meet } \\
\text { requirement }\end{array}$ & $\begin{array}{l}\text { Must meet } \\
\text { requirement }\end{array}$ & $\begin{array}{c}\text { Must meet } \\
\ldots . . . . \\
\text { of the } \\
\text { requirement }^{c}\end{array}$ & $\begin{array}{c}\text { Must meet } \\
\ldots \ldots . . . . \\
\text { of the } \\
\text { requirement }^{\mathrm{d}}\end{array}$ & Form FIN - 2 \\
\hline
\end{tabular}

a The amount stated should normally not be less than two times the annualized value of the subject contract, expressed as $2 \times \mathrm{V} / \mathrm{T}$; where $V$ is the Employer's estimated cost (including contingencies), and $T$ is the contract duration in years. For contract duration of up to 1 year, T of " 1 " should be used. The multiplier 2 may be reduced for very large contracts but should not be less than 1.5 .

b Insert number of years in words and figures and indicate time period between 3 and 5 years.

c The Employer is to define this value based on the minimum amount required for all partners of the Joint Venture to meet, taking joint and several liability into account, usually at least $25 \%$.

d The Employer is to define this value based on the minimum amount required that one partner of the Joint Venture must meet, usually at least $40 \%$. 


\subsubsection{Financial Resources ${ }^{2}$}

If the bid evaluation process and the decision for the award of the Contract takes more than 1 year from the date of bid submission, Bidders may be asked to resubmit their current contract commitments and latest information on financial resources supported by latest audited accounts/audited financial statements, or if not required by the law of the Bidder's country, other financial statements acceptable to the Employer, and the Bidders' financial capacity will be reassessed on this basis.

\begin{tabular}{|c|c|c|c|c|c|}
\hline \multirow[b]{3}{*}{ Requirement } & \multicolumn{4}{|c|}{ Compliance Requirements } & Documents \\
\hline & \multirow[b]{2}{*}{ Single Entity } & \multicolumn{3}{|c|}{ Joint Venture } & \multirow[b]{2}{*}{$\begin{array}{l}\text { Submission } \\
\text { Requirements }\end{array}$} \\
\hline & & $\begin{array}{c}\text { All Partners } \\
\text { Combined }\end{array}$ & $\begin{array}{c}\text { Each } \\
\text { Partner }\end{array}$ & $\begin{array}{c}\text { One } \\
\text { Partner }\end{array}$ & \\
\hline $\begin{array}{l}\text { For Single Entities } \\
\text { The Bidder must demonstrate that its } \\
\text { financial resources defined in Form } \\
\text { FIN - 3, less its financial obligations } \\
\text { for its current contract commitments } \\
\text { defined in Form FIN - } 4 \text {, meet or exceed } \\
\text { the total requirement for the Subject } \\
\text { Contract of ............ }\end{array}$ & $\begin{array}{l}\text { Must meet } \\
\text { requirement }\end{array}$ & $\begin{array}{c}\text { Not } \\
\text { applicable }\end{array}$ & $\begin{array}{c}\text { Not } \\
\text { applicable }\end{array}$ & $\begin{array}{c}\text { Not } \\
\text { applicable }\end{array}$ & $\begin{array}{l}\text { Form FIN }-3 \\
\text { and } \\
\text { Form FIN }-4\end{array}$ \\
\hline $\begin{array}{l}\text { For Joint Ventures } \\
\text { (1) One partner must demonstrate } \\
\text { that its financial resources defined } \\
\text { in Form FIN - 3, less its financial } \\
\text { obligations for its own current } \\
\text { contract commitments defined in } \\
\text { Form FIN }-4 \text {, meet or exceed its } \\
\text { required share of ........... b from the } \\
\text { total requirement for the Subject } \\
\text { Contract. }\end{array}$ & $\begin{array}{c}\text { Not } \\
\text { applicable }\end{array}$ & $\begin{array}{c}\text { Not } \\
\text { applicable }\end{array}$ & $\begin{array}{c}\text { Not } \\
\text { applicable }\end{array}$ & $\begin{array}{l}\text { Must meet } \\
\text { requirement }\end{array}$ & $\begin{array}{c}\text { Form FIN }-3 \\
\text { and } \\
\text { Form FIN }-4\end{array}$ \\
\hline AND & & & & & \\
\hline
\end{tabular}

2 The Employer has the option to move this criterion from Section 3 (Evaluation and Qualification Criteria) to Section 6 (Employer's Requirements), in which case:

(a) the Employer shall confirm compliance with the financial resources criterion prior to award of contract in accordance with ITB 41.1 Award Criteria; and

(b) in place of the Financial Resources criterion, the Employer may require the bidder to submit together with its bid, and for confirmation during bid evaluation, a Letter of Undertaking to comply with the financial resources given in Section 6 prior to award of contract. 


\begin{tabular}{|c|c|c|c|c|c|c|}
\hline (2) & $\begin{array}{l}\text { Each partner must demonstrate } \\
\text { that its financial resources defined } \\
\text { in Form FIN - 3, less its financial } \\
\text { obligations for its own current } \\
\text { contract commitments defined in } \\
\text { Form FIN - 4, meet or exceed its } \\
\text { required share of .............. }{ }^{c} \text { from } \\
\text { the total requirement for the Subject } \\
\text { Contract. } \\
\text { AND }\end{array}$ & $\begin{array}{c}\text { Not } \\
\text { applicable }\end{array}$ & $\begin{array}{c}\text { Not } \\
\text { applicable }\end{array}$ & $\begin{array}{l}\text { Must meet } \\
\text { requirement }\end{array}$ & $\begin{array}{c}\text { Not } \\
\text { applicable }\end{array}$ & $\begin{array}{c}\text { Form FIN }-3 \\
\text { and } \\
\text { Form FIN - } 4\end{array}$ \\
\hline & Criteria & \multicolumn{4}{|c|}{ Compliance Requirements } & Documents \\
\hline \multirow{2}{*}{\multicolumn{2}{|c|}{ Requirement }} & \multirow[b]{2}{*}{ Single Entity } & \multicolumn{3}{|c|}{ Joint Venture } & \multirow[b]{2}{*}{$\begin{array}{c}\text { Submission } \\
\text { Requirements }\end{array}$} \\
\hline & & & $\begin{array}{c}\text { All Partners } \\
\text { Combined }\end{array}$ & $\begin{array}{c}\text { Each } \\
\text { Partner }\end{array}$ & $\begin{array}{c}\text { One } \\
\text { Partner }\end{array}$ & \\
\hline (3) & $\begin{array}{l}\text { The Joint Venture must demonstrate } \\
\text { that the combined financial } \\
\text { resources of all partners defined in } \\
\text { Form FIN - 3, less all the partners' } \\
\text { total financial obligations for the } \\
\text { current contract commitments } \\
\text { defined in Form FIN - 4, meet or } \\
\text { exceed the total requirement for the } \\
\text { Subject Contract of .............. }{ }^{a}\end{array}$ & $\begin{array}{c}\text { Not } \\
\text { applicable }\end{array}$ & $\begin{array}{l}\text { Must meet } \\
\text { requirement }\end{array}$ & $\begin{array}{c}\text { Not } \\
\text { applicable }\end{array}$ & $\begin{array}{c}\text { Not } \\
\text { applicable }\end{array}$ & $\begin{array}{l}\text { Form FIN }-3 \\
\text { and } \\
\text { Form FIN }-4\end{array}$ \\
\hline
\end{tabular}

a The Employer is to specify the total requirement for the Subject Contract based on the following calculation:

$$
\frac{3 \text { (or 4) } \times \text { Estimated Contract Value (Inclusive of Taxes and Duties) }}{\text { Completion Period in Months }}
$$

b The Employer is to define this value based on the minimum amount one partner of the Joint Venture must meet, usually at least $40 \%$ of the total requirement for the Subject Contract. This value is to be carried forward to Form FIN - $5 \mathrm{~B}$ when it is used.

c The Employer is to define this value based on the minimum amount each partner of the Joint Venture must meet, usually at least $25 \%$ of the total requirement for the Subject Contract. This value is to be carried forward to Form FIN - 5B when it is used.

\section{NOTE}

Form FIN - 5 is made available for use by the Bidder as a self-assessment tool, and by the Employer as an evaluation work sheet, to determine compliance with the financial resources requirement as stated in 2.3.3. Failure to submit Form FIN - 5 by the Bidder shall not lead to bid rejection. 


\subsection{Construction Experience}

\subsubsection{Contracts of Similar Size and Nature ${ }^{3}$}

\begin{tabular}{|c|c|c|c|c|c|}
\hline Criteria & \multicolumn{4}{|c|}{ Compliance Requirements } & Documents \\
\hline \multirow[b]{2}{*}{ Requirement } & \multirow[b]{2}{*}{ Single Entity } & \multicolumn{3}{|c|}{ Joint Venture } & \multirow[b]{2}{*}{$\begin{array}{c}\text { Submission } \\
\text { Requirements }\end{array}$} \\
\hline & & $\begin{array}{l}\text { All Partners } \\
\text { Combined }\end{array}$ & $\begin{array}{l}\text { Each } \\
\text { Partner }\end{array}$ & $\begin{array}{l}\text { One } \\
\text { Partner }\end{array}$ & \\
\hline $\begin{array}{l}\text { Participation as a contractor, Joint } \\
\text { Venture partner, or Subcontractor, } \\
\text { in at least one contract that has } \\
\text { been satisfactorily and substantially } \\
\text { completed within the last ....... } \\
\text { years and that is similar to the proposed } \\
\text { works, where the value of the Bidder's } \\
\text { participation exceeds } \$ \ldots \ldots . . . \text { The } \\
\text { similarity of the Bidder's participation } \\
\text { shall be based on: }{ }^{\text {de, }, f} \\
1 \ldots . . \\
2 \ldots . \\
3 \ldots .\end{array}$ & $\begin{array}{l}\text { Must meet } \\
\text { requirement }\end{array}$ & $\begin{array}{c}\text { Not } \\
\text { applicable }\end{array}$ & $\begin{array}{c}\text { Not } \\
\text { applicables }\end{array}$ & $\begin{array}{l}\text { Must meet } \\
\text { requirement }\end{array}$ & Form EXP $-1^{h}$ \\
\hline
\end{tabular}

Or

3 The Employer has the option of requiring either one or two contracts of similar size and nature and should choose the appropriate language for the table in 2.4.1. 


\begin{tabular}{|c|c|c|c|c|c|}
\hline Criteria & \multicolumn{4}{|c|}{ Compliance Requirements } & Documents \\
\hline \multirow[b]{2}{*}{ Requirement } & \multirow[b]{2}{*}{ Single Entity } & \multicolumn{3}{|c|}{ Joint Venture } & \multirow[b]{2}{*}{$\begin{array}{l}\text { Submission } \\
\text { Requirements }\end{array}$} \\
\hline & & $\begin{array}{l}\text { All Partners } \\
\text { Combined }\end{array}$ & $\begin{array}{c}\text { Each } \\
\text { Partner }\end{array}$ & $\begin{array}{c}\text { One } \\
\text { Partner }\end{array}$ & \\
\hline $\begin{array}{l}\text { Participation as a contractor, Joint } \\
\text { Venture partner, or Subcontractor, } \\
\text { in at least two contracts that have } \\
\text { been satisfactorily and substantially }{ }^{\mathrm{a}} \\
\text { completed within the last ....... } \\
\text { years and that are similar to the } \\
\text { proposed works, where the value of } \\
\text { the Bidder's participation under each } \\
\text { contract exceeds } \$ \ldots . . .{ }^{c} \text {. The similarity } \\
\text { of the Bidder's participation shall be } \\
\text { based on: }{ }^{d, e, f} \\
1 \ldots . . \\
2 \ldots . . \\
3 \ldots . .\end{array}$ & $\begin{array}{l}\text { Must meet } \\
\text { requirement }\end{array}$ & $\begin{array}{l}\text { Must meet } \\
\text { requirement as follows: } \\
\text { (i) Either one partner } \\
\text { must meet } \\
\text { requirement; or } \\
\text { (ii) any two partners } \\
\text { must each } \\
\text { demonstrate one } \\
\text { (1) successfully or } \\
\text { substantially } \\
\text { completed } \\
\text { contract of } \\
\text { similar size and } \\
\text { nature }\end{array}$ & $\begin{array}{c}\text { Not } \\
\text { applicables }\end{array}$ & $\begin{array}{c}\text { Not } \\
\text { applicable }\end{array}$ & Form EXP $-1^{\mathrm{h}}$ \\
\hline
\end{tabular}

a The requirement of "substantially completed contract" may vary from bid package to bid package. The requirement of "substantially completed contract" should be carefully reflected in the documents required to be submitted by bidders, to avoid potential issues in bid evaluation (refer Note "h" below). For further guidance on substantial completion of contracts, refer to ADB's Guidance Note on Procurement: Open Competitive Bidding

b Insert number of years in words and figures. The range is normally 5 to 10 years.

c Usually $80 \%$ of the estimated value of the subject contract. In case of repetitive and contiguous works (e.g., transmission lines, water pipeline), the Employer has the option of specifying a value that is between $50 \%$ and $80 \%$ of the subject contract value. If the contract value is not in the specific currency, the exchange rate to be used to calculate the value of the contract shall be the selling rate of the Borrower's central bank on the date of the contract signing.

d Specify major requirements in terms of any of the following: physical size, nature of works, complexity, methods, technology, or other characteristics.

e For contracts under which the Bidder participated as a Joint Venture partner or Subcontractor, only the Bidder's share, by value, shall be considered to meet this requirement.

${ }^{f}$ For contracts implemented by a Joint Venture contractor, if the Bidder comprises the same Joint Venture, the "Single Entity"requirements will apply.

g In case of complex works, the employer may require each partner to demonstrate one satisfactorily and substantially completed contract of similar nature where such partner's value of participation exceeds $25 \%$ of the subject contract value.

${ }^{h}$ In addition to the submission requirement Form EXP - 1, the bidder shall provide the following supporting documents:

[If the Employer will consider a "substantially completed contract" as one in which the works have been completed, insert the following text:

1. Signed Contract Agreement, and

2. Taking-Over Certificate, Certificate of Completion of the Works (or equivalent) or Performance Certificate, in sufficient detail to verify the contract name, value and completion time (or substantial completion). If the documents are other than in English, an accurate certified translation of these documents in English shall be provided.]

[If the Employer will consider a "substantially completed contract" as one in which the Contractor has completed all its obligations under the contract, insert the following text:

1. Signed Contract Agreement, and

2. Certificate of Completion of the Works (or equivalent) or Performance Certificate, in sufficient detail to verify the contract name, value and completion time. If the documents are other than in English, an accurate certified translation of these documents in English shall be provided.] 


\subsubsection{Construction Experience in Key Activities ${ }^{4}$}

2.4.2 (a) Must be complied with by the Bidder. In case of a Joint Venture Bidder, the Bidder or at least one of the partners must meet the requirement in the key activity. For contracts under which the Bidder participated as a Joint Venture partner, only the Bidder's designated scope of works under the contracts shall be considered to meet this requirement.

Table A

\begin{tabular}{|c|c|c|c|}
\hline Criteria & \multicolumn{2}{|c|}{ Compliance Requirements } & Documents \\
\hline Requirement & Single Entity & Joint Venture & Submission Requirements \\
\hline $\begin{array}{l}\text { For the above or other } \\
\text { contracts executed during } \\
\text { the period stipulated } \\
\text { in } 2.4 .1 \text {, a minimum } \\
\text { construction experience } \\
\text { in the following key } \\
\text { activities: }\end{array}$ & Must meet requirement & Must meet requirement & Form EXP $-2^{b}$ \\
\hline 1 ............... & & & \\
\hline $2 \ldots \ldots \ldots \ldots$ & & & \\
\hline $3 .$. etc ...... & & & \\
\hline
\end{tabular}

a Under Criterion 2.4.1, the specified requirements define the similarity of contracts, whereas the key activities or production rates to be specified under Criterion 2.4.2 define the required capability of the Bidder to execute key components of the Works. There shall be no inconsistency or duplication of requirements between Criteria 2.4.1 and 2.4.2. For the rate of production, specify that the rate of production shall be on the basis of the average during the entire specified period.

b Submission requirements: Form EXP - 2 shall be supported by documents such as Signed Contract Agreement or Certificate of Completion of the Works indicating the contract name, value. completion date (or percentage of substantial completion), activities performed by Joint Venture partners, and other relevant details sufficient to demonstrate compliance with the requirements.

These requirements for experience in key activities may be waived in simple contracts.

$4 \quad$ Key activities criterion should only test the Bidder's experience in performing highly specialized construction activities (e.g., tunneling, dredging, and bridge construction) and achievement of specified production rates. 
2.4.2. (b) The Employer accepts any of the following activities to be subcontracted. They may be complied with by the Bidder or by its proposed Specialist Subcontractor.

If the key activity is to be undertaken by a Specialist Subcontractor, the Employer shall require evidence of the subcontracting agreement from the Bidder.

Table B

\begin{tabular}{|c|c|c|c|}
\hline Criteria & \multicolumn{2}{|c|}{ Compliance Requirements } & Documents \\
\hline Requirement & $\begin{array}{c}\text { Single Entity or its } \\
\text { Specialist Subcontractors }\end{array}$ & $\begin{array}{c}\text { Joint Venture or its } \\
\text { Specialist Subcontractors }\end{array}$ & Submission Requirements \\
\hline $\begin{array}{l}\text { For the above or other } \\
\text { contracts executed during } \\
\text { the period stipulated } \\
\text { in } 2.4 .1 \text {, a minimum } \\
\text { construction experience } \\
\text { is required in the following } \\
\text { key activities: a,b }\end{array}$ & Must meet requirement & Must meet requirement & Form EXP $-2^{c}$ \\
\hline \multicolumn{4}{|l|}{$4 \ldots \ldots \ldots \ldots$} \\
\hline \multicolumn{4}{|l|}{$5 \ldots \ldots \ldots \ldots . . .}$. \\
\hline $6 .$. etc ....... & & & \\
\hline
\end{tabular}

a Under Criterion 2.4.1, the specified requirements define the similarity of contracts, whereas the key activities or production rates to be specified under Criterion 2.4.2 define the required capability of the Bidder to execute key components of the Works. There shall be no inconsistency or duplication of requirements between Criteria 2.4.1 and 2.4.2. For the rate of production, specify that the rate of production shall be on the basis of the average during the entire specified period.

b The compliance requirement for each key activity that may be met by a specialist subcontractor must define whether the requirement can only be met by a single specialist subcontractor or whether two or more specialist subcontractors can jointly meet the requirement.

c Submission requirements: Form EXP - 2 shall be supported by documents such as Signed Contract Agreement or Certificate of Completion of the Works indicating the contract name, value. completion date (or percentage of substantial completion), activities performed by Joint Venture partners, and other relevant details sufficient to demonstrate compliance with the requirements.

These requirements for experience in key activities may be waived in simple contracts. 


\subsubsection{Specific Experience in Managing Environmental, Health and Safety Aspects}

\begin{tabular}{|c|c|c|c|}
\hline Criteria & \multicolumn{2}{|c|}{ Compliance Requirements } & Documents \\
\hline Requirement & $\begin{array}{c}\text { Single Entity or its } \\
\text { Specialist Subcontractors }\end{array}$ & $\begin{array}{c}\text { Joint Venture or its } \\
\text { Specialist Subcontractors }\end{array}$ & Submission Requirements \\
\hline $\begin{array}{l}\text { For the contracts in } \\
2.4 .1 \text { and } 2.4 .2 \text { above } \\
\text { and/or any other } \\
\text { contracts [substantially } \\
\text { completed and under } \\
\text { implementation] as prime } \\
\text { contractor, Joint Venture } \\
\text { partner, or Subcontractor } \\
\text { between 1st January } \\
\ldots . . .{ }^{a} \text { and Bid submission } \\
\text { deadline, experience in } \\
\text { managing EHS risks and } \\
\text { impacts in the following } \\
\text { aspects: }\end{array}$ & Must meet requirement & $\begin{array}{l}\text { One member must meet } \\
\text { requirements } \\
\text { Or } \\
\text { All members must meet } \\
\text { requirements }\end{array}$ & Form EXP -3 \\
\hline
\end{tabular}

a Insert year.

b Based on the EHS assessment, specify, as appropriate, specific experience requirements to manage EHS aspects.

\subsection{Organizational Environmental, Health and Safety System}

\subsubsection{Environmental, Health and Safety Certification}

\begin{tabular}{|l|c|c|c|}
\hline \multicolumn{1}{|c|}{ Criteria } & \multicolumn{2}{c|}{ Compliance Requirements } & Documents \\
\hline Requirement & $\begin{array}{c}\text { Single Entity or Its } \\
\text { Specialist Subcontractors }\end{array}$ & $\begin{array}{c}\text { Joint Venture or Its } \\
\text { Specialist Subcontractors }\end{array}$ & $\begin{array}{c}\text { Submission } \\
\text { Requirements }\end{array}$ \\
\hline $\begin{array}{l}\text { Availability of a valid ISO certification } \\
\text { or internationally recognized } \\
\text { equivalent (equivalency to be } \\
\text { demonstrated by the Bidder), and } \\
\text { applicable to the worksite: }\end{array}$ & Must meet requirement & $\begin{array}{c}\text { One member must meet } \\
\text { requirements }\end{array}$ & Form EXP - 4 \\
\hline $1 \ldots \ldots . . . .$. & $\begin{array}{c}\text { Oll members must meet } \\
\text { requirements }\end{array}$ & \\
\hline $2 \ldots . . . . . . .$. & & & \\
\hline $3 \ldots . . . . . . . .$. & & & \\
\hline
\end{tabular}

a Examples of certification that can be selected:

1 Quality management certificate ISO 9001

2 Environmental management certificate ISO 14001

3 Health and Safety management certificate ISO 45001

b According to the environmental, health and safety issues of the worksite and the type of competition planned (national or international), it can be decided to not to keep this criterion or only to ask for part of the certifications, specifically the one(s) corresponding to the main issue of the worksite management. 
2.5.2 Environmental, Health and Safety Documentation

\begin{tabular}{|c|c|c|c|}
\hline Criteria & \multicolumn{2}{|c|}{ Compliance Requirements } & Documents \\
\hline Requirement & $\begin{array}{c}\text { Single Entity or Its } \\
\text { Specialist Subcontractors }\end{array}$ & $\begin{array}{c}\text { Joint Venture or Its } \\
\text { Specialist Subcontractors }\end{array}$ & $\begin{array}{l}\text { Submission } \\
\text { Requirements }\end{array}$ \\
\hline $\begin{array}{l}\text { Availability of in-house policies and } \\
\text { procedures for EHS management: } \\
\text { For example: } \\
\text { 1. Existence of an Ethics Charter. } \\
\text { 2. Existence of a system for } \\
\text { monitoring compliance with EHS } \\
\text { commitments for the Bidder's } \\
\text { Subcontractors and all its partners. } \\
\text { 3. Existence of official company } \\
\text { procedures for the management of } \\
\text { the following: }{ }^{\text {a }} \\
\text { - ....... } \\
\text { - ....... } \\
\text { - ....... } \\
\text { - ....... } \\
\text { - ....... }\end{array}$ & Must meet requirement & $\begin{array}{l}\text { One member must meet } \\
\text { requirements } \\
\text { Or } \\
\text { All members must meet } \\
\text { requirements }\end{array}$ & Form EXP - 5 \\
\hline
\end{tabular}

a From the below options, the Employer to select 3-5 that apply to the worksite. The selection should be based on the most pressing EHS issues pertaining to the worksite as detailed in the project EMP.

- EHS resources and facilities and EHS monitoring system;

- Project Areas management information (base camps, quarries, burrow pits, storage areas);

- Health and Safety on worksites policy and related guidance;

- Local recruitment and EHS trainings of local staff/subcontractors/local partners;

- Community stakeholder engagement practice;

- Traffic management practice;

- Hazardous products management practice;

- Waste management practice;

- Protection of water resources;

- Biodiversity protection practices;

- Site rehabilitation and revegetation practice;

- Local cultural heritage protection practice;

- Erosion and sedimentation practices;

- Control of infectious and communicable diseases (HIV/AIDS, malaria, COVID-19 etc)

\subsubsection{Environmental, Health and Safety Dedicated Personnel}

\begin{tabular}{|l|c|c|c|}
\hline \multicolumn{1}{|c|}{ Criteria } & \multicolumn{1}{|c|}{ Compliance Requirements } & Documents \\
\hline \multicolumn{1}{|c|}{ Requirement } & $\begin{array}{c}\text { Single Entity or its } \\
\text { Specialist Subcontractors }\end{array}$ & $\begin{array}{c}\text { Joint Venture or its } \\
\text { Specialist Subcontractors }\end{array}$ & $\begin{array}{c}\text { Submission } \\
\text { Requirements }\end{array}$ \\
\hline $\begin{array}{l}\text { Availability of in-house personnel } \\
\text { dedicated to EHS issues: }\end{array}$ & Must meet requirement & $\begin{array}{c}\text { One member must meet } \\
\text { requirements }\end{array}$ & Form EXP-6 \\
- Environmental Specialist & & Or & \\
- Health and Safety Specialist & & $\begin{array}{c}\text { All members must meet } \\
\text { requirements }\end{array}$ & \\
\hline
\end{tabular}




\section{Section 4: Bidding Forms}

This section contains the forms to be completed by the Bidder and submitted as part of its Bid.

\section{Table of Forms}

Letter of Bid

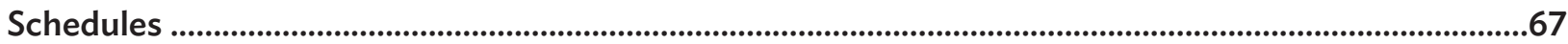

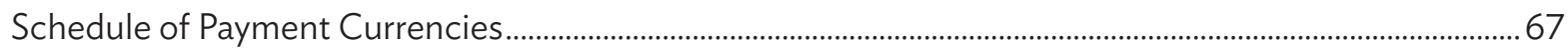

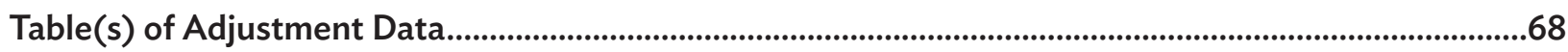

Table A - Local Currency Payment ......................................................................................................................68

Table B - Foreign Currency Payment .................................................................................................................... 68

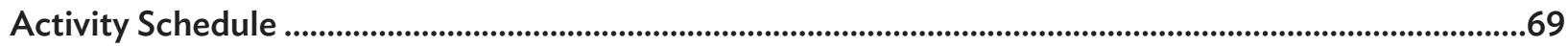

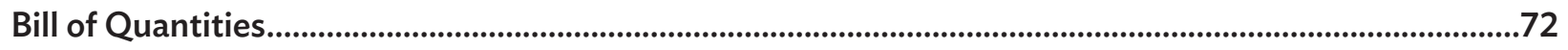

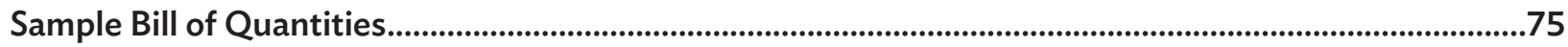

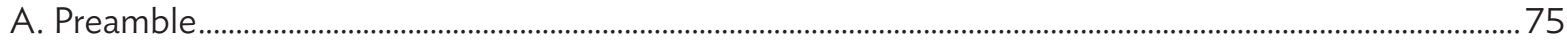

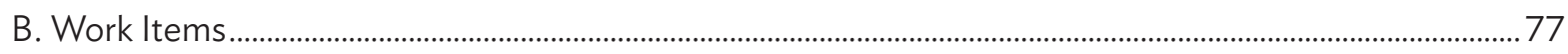

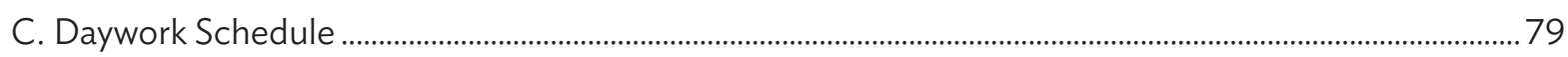

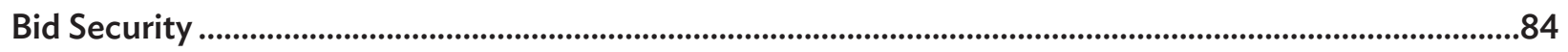

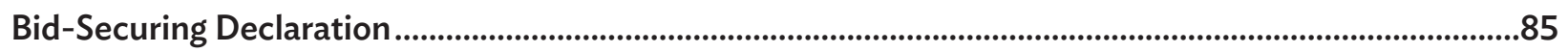

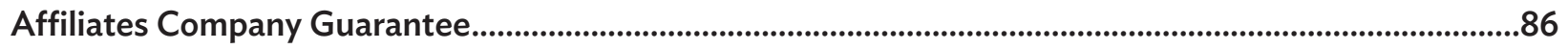

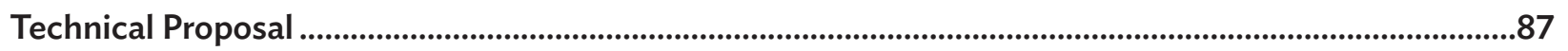

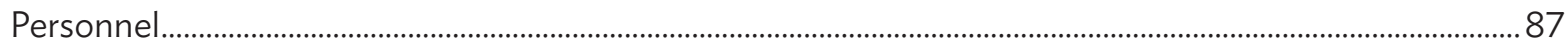

Form PER - 1: Proposed Personnel ..........................................................................................................8 87

Form PER - 2: Resumé of Proposed Personnel .................................................................................. 88

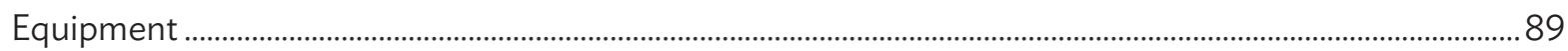

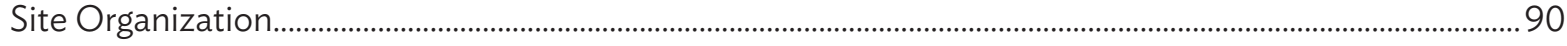

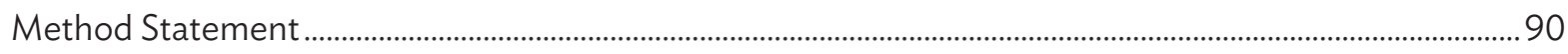

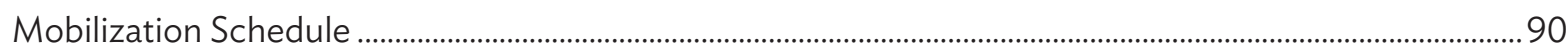

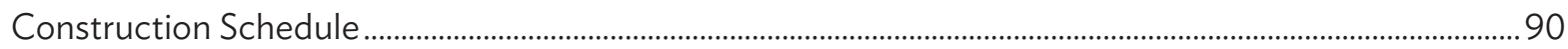

Environmental, Health and Safety Management Plan ..........................................................................................90

Environmental, Health and Safety Code of Conduct............................................................................................. 91 
Bidder's Qualification. .95

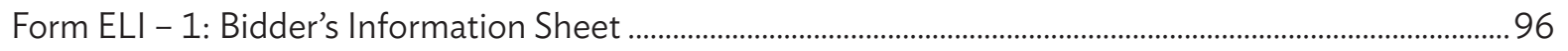

Form ELI - 2: Joint Venture Information Sheet ..........................................................................................................97

Form CON - 1: Historical Contract Nonperformance ..................................................................................... 98

Form CON - 2: EHS Performance Declaration ................................................................................................ 100

Form FIN - 1: Historical Financial Performance .................................................................................................... 102

Form FIN - 2: Average Annual Construction Turnover ................................................................................. 103

Form FIN - 3: Availability of Financial Resources ....................................................................................... 104

Form FIN - 4: Financial Requirements for Current Contract Commitments............................................. 105

Form FIN - 5: Self-Assessment Tool for Bidder's Compliance to Financial Resources ............................ 106

Form EXP - 1: Contracts of Similar Size and Nature ............................................................................... 107

Form EXP - 2: Construction Experience in Key Activities............................................................................ 108

Form EXP - 3: Specific Experience in Managing Environmental, Health and Safety Aspects................ 109

Form EXP - 4: Environmental, Health and Safety Certification..................................................................... 109

Form EXP - 5: Environmental, Health and Safety Documentation ............................................................ 110

Form EXP - 6: Environmental, Health and Safety Dedicated Personnel ................................................... 110 


\section{Letter of Bid}

\section{NOTE}

The Bidder must accomplish the Letter of Bid on its letterhead clearly showing the Bidder's complete name and address.

Date:

OCB No.:

Invitation for Bid No.:

To: [insert complete name of the Employer]

We, the undersigned, declare that:

a) We have examined and have no reservations to the Bidding Documents, including Addenda issued in accordance with Instructions to Bidders (ITB) 8 .

b) We acknowledge that we have read and understand ADB's Anticorruption Policy (1998) and Integrity Principles and Guidelines (2015), both as amended from time to time.

c) We offer to execute in conformity with the Bidding Documents the following Works: [insert narrative]

d) The total price of our Bid, excluding any discounts offered in item (d) below is:

[amount of foreign currency in words], [amount in figures], and [amount of local currency in words], [amount in figures]

The total bid price from the Summary of Bill of Quantities for admeasurement contracts or Activity Schedule for lump sum contracts should be entered by the Bidder inside this box. Absence of the total bid price in the Letter of Bid may result in the rejection of the bid.

e) The discounts offered and the methodology for their application are as follows: [insert discounts and methodology for their application if any]

f) Our Bid shall be valid for a period of [insert bid validity period as specified in ITB 18.1 of the BDS] days starts from the date fixed for the bid submission deadline in accordance with ITB 22.1, and it shall remain binding upon us and may be accepted at any time before the expiration of that period.

g) If our bid is accepted, we commit to obtain a performance security in accordance with the Bidding Document.

h) Our firm, including any Subcontractors or Suppliers for any part of the Contract, have nationalities from eligible countries in accordance with ITB 4.2. 
i) We, our directors, key officers, key personnel, including any Subcontractors, consultants, subconsultants, manufacturers, service providers or Suppliers for any part of the contract, do not have any conflict of interest in accordance with ITB 4.3.

If there is any conflict of interest, please state details:

(i) Parties involved in the conflict of interest:

(ii) Details about the conflict of interest:

j) We are not participating, as a Bidder, either individually or as partner in a Joint Venture, in more than one Bid in this bidding process in accordance with ITB 4.3(e), other than alternative offers submitted in accordance with ITB 13.

k) Our firm, Joint Venture partners, our respective direct and indirect shareholders, directors, key officers, key personnel, associates, parent company, affiliates or subsidiaries, including any Subcontractors, consultants, subconsultants, manufacturers, service providers or Suppliers for any part of the contract, are not subject to, or not controlled by any entity or individual that is subject to, a temporary suspension or a debarment imposed by the Asian Development Bank or a debarment imposed by the Asian Development Bank in accordance with the Agreement for Mutual Enforcement of Debarment Decisions between the Asian Development Bank and other development banks. ${ }^{1}$

I) Our firm, Joint Venture partners, our respective direct and indirect shareholders, directors, key officers, key personnel, associates, parent company, affiliates or subsidiaries, including any Subcontractors, consultants, subconsultants, manufacturers, service providers or Suppliers for any part of the contract, are not under ongoing investigation and/or sanctions proceedings by the Asian Development Bank or any multilateral development bank.

If under ongoing investigation and/or sanction proceedings by the Asian Development Bank or any multilateral development bank, please state details:

(i) Name of the multilateral development bank:

(ii) Reason for the ongoing investigation / allegations:

m) Our firm, Joint Venture partners, our respective direct and indirect shareholders, directors, key officers, key personnel, associates, parent company, affiliates or subsidiaries, including any Subcontractors, consultants, subconsultants, manufacturers, service providers or Suppliers for any part of the Contract, are not temporarily suspended, debarred, declared ineligible, or subject to any national and/or international sanctions by any country, any international organization, any multilateral development bank and other donor agency.

If so temporarily suspended, debarred, declared ineligible, or subject to any national and/or international sanctions by any country, any international organization, any multilateral development bank and other donor agency, please state details (as applicable to each Joint Venture partner, their respective direct or indirect shareholders, directors, key officers, key personnel, associate, parent

1 These institutions include African Development Bank, European Bank for Reconstruction and Development (EBRD), InterAmerican Development Bank (IADB), and the World Bank Group. According to paragraph 9 of the Agreement, other international financial institutions may join upon the consent of all Participating Institutions and signature of a Letter of Adherence by the international financial institution substantially in the form provided (Annex B to the Agreement). Upon adherence, such international financial institution shall become a Participating Institution for purposes of the Agreement. Bidders are advised to check www.adb.org/integrity for updates. 
company, affiliate, subsidiaries, Subcontractors, consultants, subconsultants, manufacturers, service providers and/or Suppliers):

(i) Name of Institution:

(ii) Period of the temporary suspension, debarment, ineligibility, or national or international sanction [start and end date]:

(iii) Reason for the temporary suspension, debarment, ineligibility, or national or international sanction:

n) Our firm, Joint Venture partners, associates, parent company, affiliates or subsidiaries, including any Subcontractors, consultants, subconsultants, manufacturers, service providers, Suppliers, key officers, directors, and key personnel have never been charged or convicted with any criminal offense (including felonies but excluding misdemeanors) or infractions and/or violations of ordinance; nor charged or found liable in any civil or administrative proceedings in the last 10 years; or undergoing investigation for such, or subject to any criminal, civil or administrative orders, monitorship or enforcement actions.

If so charged, convicted found liable, under ongoing investigation, or subject to orders, monitorship or enforcement actions, please state details:

(i) Nature of the offense, violation, proceedings, investigation, and/or monitorship or enforcement actions:

(ii) Court, area of jurisdiction and/or the enforcement agency:

(iii) Resolution [i.e. dismissed; settled; or convicted/duration of penalty]:

(iv) Other relevant details [please specify]:

o) Our firm, Joint Venture partners, our respective direct and indirect shareholders, directors, key officers, key personnel, associates, affiliates or subsidiaries, including any Subcontractors, consultants, subconsultants, manufacturers, service providers or Suppliers, can make and receive electronic fund transfer payments through the international banking system or otherwise discharge the Employer's obligation upon initiation of wire transfer.

If unable to make or receive funds through the international banking system or otherwise discharge the Employer's obligation upon initiation of wire transfer, please state the details:

(i) Nature of the restriction:

(ii) Jurisdiction of the restriction:

(iii) Other relevant details:

p) Our firm, Joint Venture partners, associates, parent company, affiliates or subsidiaries, including any Subcontractors, consultants, subconsultants, manufacturers, service providers or Suppliers, key officers, directors and key personnel are not from a country which is prohibited to export goods or services to, or receive any payments from the Employer's country and/or are not prohibited to receive payments for particular goods or services by the Employer's country by an act of compliance with a decision of the United Nations Security Council taken under Chapter VII of the Charter of the United Nations. 
q) We understand that it is our obligation to notify the Employer of any changes in connection with the matters described in paragraphs (i), (k), (I), (m), (n), (o), (p) and (t) of this Letter of Bid.

r) [We are not a government-owned enterprise] / [We are a government-owned enterprise but meet the requirements of ITB 4.5]. ${ }^{2}$

s) We have not been suspended nor declared ineligible by the Employer based on execution of a Bid-Securing Declaration in accordance with ITB 4.6.

t) We have paid, or intend to I pay, either directly or indirectly, the following commissions, gratuities, or fees with respect to the bidding process or execution of the Contract: ${ }^{3}$

Name of Recipient

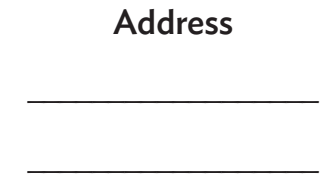

Reason

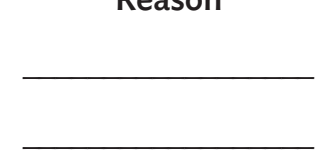

Amount

u) We understand that this Bid, together with your written acceptance thereof included in your notification of award through the issuance of Letter of Acceptance, shall constitute a binding contract between us, until a formal contract is prepared and executed.

v) We understand that you are not bound to accept the lowest evaluated Bid or any other Bid that you may receive.

w) At any time following submission of our Bid, we shall permit, and shall cause our Joint Venture partners, directors, key officers, key personnel, associates, parent company, affiliates or subsidiaries, including any Subcontractors, consultants, subconsultants, manufacturers, service providers or Suppliers for any part of the contract to permit ADB or its representative to inspect our site, assets, accounts and records and other documents relating to the bid submission and to have them audited by auditors appointed by $A D B$. We understand that failure of this obligation may constitute obstructive practice that may result in debarment and/or contract termination.

x) Regardless of whether the contract will be awarded to us, we shall preserve all accounts, records and other documents related to bid submission for at least 3 years from the date of submission of the bid or the period prescribed in applicable law, whichever is longer.

y) If we are awarded the contract, we shall preserve all accounts, records and other documents related to the procurement and execution of the contract for at least 5 years after completing the works contemplated in the relevant contracts or the period prescribed in applicable law, whichever is longer.

Use one of the two options as appropriate

If none has been paid or is to be paid, indicate "None." 
z) If our Bid is accepted, we commit to mobilizing key equipment and personnel in accordance with the requirements set forth in Section 6 (Employer's Requirements) and our technical proposal, or as otherwise agreed with the Employer.

aa) We certify on behalf of the Bidder, that the information provided in the bid has been fully reviewed, given in good faith, and to the best of our knowledge is true and complete. We understand that it is our obligation to inform the Employer of any changes to the information as and when it becomes known to us. We understand that any misrepresentation that knowingly or recklessly misleads, or attempts to mislead may lead to the automatic rejection of the Bid or cancellation of the contract, if awarded; and may result in remedial actions, in accordance with ADB's Anticorruption Policy (1998, as amended to date) and Integrity Principles and Guidelines (2015, as amended from time to time).

Name: [insert complete name of person signing the bid]

In the capacity of [insert legal capacity of person signing the bid]

Signed: [insert signature of person whose name and capacity are shown above]

Duly authorized to sign the Bid for and on behalf of [insert complete name of the Bidder]

Date: [insert date of signing] 


\section{Schedules}

\section{Schedule of Payment Currencies}

For insert name of Section of the Works

Separate tables may be required if the various sections of the Works (or of the Bill of Quantities) will have substantially different foreign and local currency requirements. In such a case, the Employer should prepare separate tables for each Section of the Works.

\begin{tabular}{|c|c|c|c|c|}
\hline $\begin{array}{l}\text { Name of Payment } \\
\text { Currency }\end{array}$ & $\begin{array}{l}\text { Amount of } \\
\text { Currency }\end{array}$ & $\begin{array}{l}\text { Rate of Exchange } \\
\text { to Local Currency }\end{array}$ & $\begin{array}{c}\text { C } \\
\text { Local Currency } \\
\text { Equivalent } \\
\text { C }=\mathrm{A} \times \mathrm{B}\end{array}$ & $\begin{array}{c}\text { D } \\
\text { Percentage of Net } \\
\text { Bid Price (NBP) } \\
\frac{100 \times C}{\text { NBP }}\end{array}$ \\
\hline Local Currency & & 1.00 & & \\
\hline \multicolumn{5}{|l|}{ Foreign Currency \#1 } \\
\hline \multicolumn{5}{|l|}{ Foreign Currency \#2 } \\
\hline \multicolumn{5}{|l|}{ Foreign Currency \#3 } \\
\hline Net Bid Price & & & & 100.00 \\
\hline $\begin{array}{l}\text { Provisional Sums } \\
\text { Expressed in } \\
\text { Local Currency }\end{array}$ & $\begin{array}{c}\text { To be entered by the } \\
\text { Employer }\end{array}$ & 1.00 & $\begin{array}{c}\text { To be entered by the } \\
\text { Employer }\end{array}$ & \\
\hline BID PRICE & & & & \\
\hline
\end{tabular}

\section{NOTE}

The rates of exchange shall be the selling rates 28 days prior to the deadline for submission of bids published by the source specified in BDS 15. 


\section{Table(s) of Adjustment Data}

\section{Table A - Local Currency Payment}

\begin{tabular}{|c|c|c|c|c|c|}
\hline Index Code & $\begin{array}{c}\text { Index } \\
\text { Description }\end{array}$ & Source of Index & $\begin{array}{l}\text { Base Value } \\
\text { and Date }\end{array}$ & $\begin{array}{c}\text { Bidder's Proposec } \\
\text { Weighting }\end{array}$ & \\
\hline L: Labor & Nonadjustable & - & - & a. $0.10 \sim 0.20$ & \\
\hline E: Equipment & & & & b. ) & $\begin{array}{l}\text { To be entered } \\
\text { by the Biddder }\end{array}$ \\
\hline M1: Material 1 & & & & c. & (Employer \\
\hline M2: Material 2 & & & & d. & $\begin{array}{l}\text { may prescribe } \\
\text { the range of }\end{array}$ \\
\hline ..etc.. & & & & e. & weighting) \\
\hline & & & Total & 1.00 & \\
\hline
\end{tabular}

\section{Table B - Foreign Currency Payment}

Name of Currency: [insert name of currency. If the Bidder wishes to quote in more than one foreign currency, this table should be repeated for each foreign currency such as \#1, \#2, and \#3]

\begin{tabular}{|c|c|c|c|c|c|}
\hline Index Code & $\begin{array}{l}\text { Index } \\
\text { Description }\end{array}$ & Source of Index & $\begin{array}{c}\text { Base Value and } \\
\text { Date }\end{array}$ & $\begin{array}{l}\text { Bidder's Proposed } \\
\text { Weighting }\end{array}$ & \\
\hline L: Labor & Nonadjustable & - & - & a. $0.10 \sim 0.20$ & \multirow{5}{*}{$\begin{array}{l}\text { To be entered } \\
\text { by the Bidder } \\
\text { (Employer } \\
\text { may prescribe } \\
\text { the range of } \\
\text { weighting) }\end{array}$} \\
\hline E: Equipment & & & & b. & \\
\hline M1: Material 1 & & & & & \\
\hline M2: Material 2 & & & & & \\
\hline ..etc.. & & & & e. & \\
\hline & & & Total & 1.00 & \\
\hline
\end{tabular}

\section{NOTES}

"Base Date" means the date 28 days prior to the deadline for submission of bids.

For a given currency, the "Source of Index" should be issued or published within the country to which the currency relates.

Tables of Adjustment Data shall only be included if prices are to be quoted as adjustable prices in accordance with ITB 14.5. 


\section{Activity Schedule}

\section{[Schedules of Prices - Lump Sum Contract]}

The Employer shall indicate the list of major activities comprising the works and the number of measurement units consistent with the description of works, drawings, and specifications in Section 6 (Employer's Requirements). Each work item shall be described in sufficient detail to provide clear guidance to Bidders with respect to the type of works, their scope and complexity, and compliance with the required standards.

Bidders are required to enter the prices against each work item on a lump sum basis. Work items against which no lump sum price is entered by the Bidder will not be paid by the Employer when executed and shall be deemed covered by other work items against which the lump sum prices were entered. The sum of prices entered against each work item will represent the total bid price.

The whole cost of complying with the provisions of the Contract shall be included in the ltems provided in the Activity Schedule, and where no Items are provided, the cost shall be deemed to be distributed among the Amounts for the related Items of Work.

\section{Sample Activity Schedule}

\section{Construction of Building Structure}

\begin{tabular}{|c|l|l|l|}
\hline Item no. & \multicolumn{1}{|c|}{ Description } & \multicolumn{1}{c|}{ Unit } & Amount \\
\hline A. Substructure & & \\
\hline 1 & Earthwork & & \\
\hline 1.1 & Excavation works $\left(1,250 \mathrm{~m}^{3}\right)$ & & \\
\hline 1.2 & Backfilling $\left(1,415 \mathrm{~m}^{3}\right)$ & & \\
\hline 2 & Concrete Works & & \\
\hline 2.1 & Concrete for footing $\left(350 \mathrm{~m}^{3}\right)$ & & \\
\hline 2.2 & Column necks $\left(360 \mathrm{~m}^{3}\right)$ & & \\
\hline 3 & Waterproofing Works & & \\
\hline B. Superstructure & Ground Floor & & \\
\hline 4 & Ground Floor Columns $\left(310 \mathrm{~m}^{3}\right)$ & & \\
\hline 4.1 & Ground Floor Slab and Stairs $\left(785 \mathrm{~m}^{3}\right)$ & & \\
\hline 4.2 & First Floor & First Floor Columns $\left(310 \mathrm{~m}^{3}\right)$ & \\
\hline 5 & & & \\
\hline 5.1 & & & \\
\hline
\end{tabular}




\begin{tabular}{|c|l|c|c|}
\hline Item no. & Description & Unit & Amount \\
\hline 5.2 & First Floor Slab and Stairs $\left(785 \mathrm{~m}^{3}\right)$ & & \\
\hline etc. & & & \\
\hline
\end{tabular}

C. Rough Finishes

\begin{tabular}{|c|l|l|l|}
\hline 6 & Ground Floor & & \\
\hline 6.1 & Masonry Works $\left(1,055 \mathrm{~m}^{2}\right)$ & & \\
\hline 6.2 & Ceramic Tiles $\left(1,925 \mathrm{~m}^{2}\right)$ & & \\
\hline 7 & First Floor & & \\
\hline 7.1 & Masonry Works $\left(1,055 \mathrm{~m}^{2}\right)$ & & \\
\hline 7.2 & Ceramic Tiles $\left(1,925 \mathrm{~m}^{2}\right)$ & & \\
\hline etc. & & & \\
\hline
\end{tabular}

D. Final Finishes

\begin{tabular}{|c|l|l|l|}
\hline 8 & Ground Floor & & \\
\hline 8.1 & Paint Works $\left(3,655 \mathrm{~m}^{2}\right)$ & & \\
\hline 8.2 & Doors and Windows $(165)$ & & \\
\hline 9 & First Floor & & \\
\hline 9.1 & Paint Works $\left(3,655 \mathrm{~m}^{2}\right)$ & & \\
\hline 9.2 & Doors and Windows $(165)$ & & \\
\hline etc. & & & \\
\hline
\end{tabular}

\section{E. Electrical Works}

\begin{tabular}{|c|l|l|l|}
\hline 10 & Ground Floor & & \\
\hline 10.1 & Panel boards, Wiring Devices, and Circuit Breaker Installations & & \\
\hline 10.2 & Socket Outlets, Lighting Fixtures, and Switches & & \\
\hline 11 & First Floor & & \\
\hline 11.1 & Panel boards, Wiring Devices, and Circuit Breaker Installations & & \\
\hline 11.2 & Socket Outlets, Lighting Fixtures, and Switches & & \\
\hline etc. & & & \\
\hline F. Mechanical Works & & \\
\hline 12 & Ground Floor & & \\
\hline 12.1 & Pipes and Fittings $(1,415 \mathrm{~m})$ & & \\
\hline 12.2 & Plumbing & & \\
\hline
\end{tabular}




\begin{tabular}{|c|l|c|c|}
\hline Item no. & \multicolumn{1}{|c|}{ Description } & Unit & Amount \\
\hline 12.3 & Cooling System & & \\
\hline 13 & First Floor & & \\
\hline 13.1 & Pipes and Fittings $(1,250 \mathrm{~m})$ & & \\
\hline 13.2 & Plumbing & & \\
\hline 13.3 & Cooling System & & \\
\hline
\end{tabular}

G. Other Works

\begin{tabular}{|l|l|l|l|}
\hline 14 & Elevator System & & \\
\hline 15 & Security System (CCTV, etc.) & & \\
\hline 16 & Generator System & & \\
\hline 17 & Fencing & & \\
\hline 18 & Landscaping & & \\
\hline etc. & & & \\
\hline & TOTAL BID PRICE to be carried forward to Letter of Bid & & \\
\hline
\end{tabular}

NOTE In the case of Admeasurement Contract, use the "Bill of Quantities." 


\section{Bill of Quantities}

\section{[Admeasurement Contract]}

\section{Objectives}

The objectives of the Bill of Quantities are

(a) to provide sufficient information on the quantities of Works to be performed to enable bids to be prepared efficiently and accurately; and

(b) when a contract has been entered into, to provide a priced Bill of Quantities for use in the periodic valuation of Works executed.

To attain these objectives, Works should be itemized in the Bill of Quantities in sufficient detail to distinguish between the different classes of Works, or between Works of the same nature carried out in different locations or in other circumstances that may give rise to different considerations of cost. Consistent with these requirements, the layout and content of the Bill of Quantities should be as simple and brief as possible.

\section{Content}

The Bill of Quantities should be divided generally into the following sections:
(a) Preamble,
(b) Work Items (grouped into parts),
(c) Daywork Schedule, and
(d) Summary.

\section{Preamble}

The Preamble should indicate the inclusiveness of the unit prices, and should state the methods of measurement that have been adopted in the preparation of the Bill of Quantities and that are to be used for the measurement of any part of the Works.

\section{Rock}

Where excavation, boring, or driving is included in the Works, a comprehensive definition of rock (always a contentious topic in contract administration), if not given in the Technical Specification, should be given in the Preamble, and this definition should be used for the purposes of measurement and payment.

\section{Work Items}

The items in the Bill of Quantities should be grouped into sections to distinguish between those parts of the Works, which by nature, location, access, timing, or any other special characteristics may give rise to different methods of construction, phasing of the Works, or considerations of cost. General items common to all parts of the Works may be grouped as a separate section in the Bill of Quantities. When families of Price Adjustment Formulas are used, they should relate to appropriate sections in the Bill of Quantities. 


\section{Quantities}

Quantities should be computed net from the Drawings, unless directed otherwise in the Contract, and no allowance should be made for bulking, shrinkage, or waste. Quantities should be rounded up or down where appropriate, and spurious accuracy should be avoided.

\section{Units of Measurement}

The following units of measurement and abbreviations are recommended for use unless other national units are mandatory in the country of the Employer.

\begin{tabular}{|l|l|l|l|}
\hline \multicolumn{1}{|c|}{ Unit } & Abbreviation & \multicolumn{1}{c|}{ Unit } & Abbreviation \\
\hline cubic meter & $\mathrm{m}^{3}$ or cu m & metric ton & $\mathrm{t}$ \\
hectare & $\mathrm{ha}$ & $(1,000 \mathrm{~kg})$ & $\mathrm{mm}$ \\
hour & $\mathrm{h}$ & millimeter & $\mathrm{mon}$ \\
kilogram & $\mathrm{kg}$ & month & number \\
kilowatt & $\mathrm{kW}$ & square meter & $\mathrm{nr}$ \\
lump sum & $\mathrm{sum}$ & square millimeter & $\mathrm{mm}^{2}$ or $\mathrm{m}$ \\
meter & $\mathrm{m}$ & week $\mathrm{mm}$ \\
& & $\mathrm{wk}$ \\
\hline
\end{tabular}

\section{Ground and Excavation Levels}

The commencing surface should be identified in the description of each item for work involving excavation, boring, or driving, for which the commencing surface is not also the original surface. The excavated surface should be identified in the description of each item for work involving excavation for which the excavated surface is not also the final surface. The depths of work should be measured from the commencing surface to the excavated surface, as defined.

\section{Daywork Schedule}

A Daywork Schedule should be included if the probability of unforeseen work, outside the items included in the Bill of Quantities, is relatively high. To facilitate checking by the Employer of the realism of rates quoted by the Bidders, the Daywork Schedule should normally comprise

(a) a list of the various classes of labor, materials, and Contractor's Equipment for which basic Daywork rates or prices are to be inserted by the Bidder, together with a statement of the conditions under which the Contractor will be paid for work executed on a Daywork basis; and

(b) a percentage to be entered by the Bidder against each basic Daywork Subtotal amount for labor, materials, and plant representing the Contractor's profit, overheads, supervision, and other charges. 


\title{
Provisional Quantities and Sums
}

Provision for quantity contingencies in any particular item or class of work with a high expectation of quantity overrun should be made by entering specific "Provisional Quantities" or "Provisional Items" in the Bill of Quantities, and not by increasing the quantities for that item or class of work beyond those of the work normally expected to be required. To the extent not covered above, a general provision for physical contingencies (quantity overruns) should be made by including a "Provisional Sum" in the Summary of the Bill of Quantities. Similarly, a contingency allowance for possible price increases should be provided as a "Provisional Sum" in the Summary of the Bill of Quantities. The inclusion of such Provisional Sums often facilitates budgetary approval by avoiding the need to request periodic supplementary approvals as future needs arise.

The estimated cost of specialized work to be carried out, or of special goods to be supplied, by a Nominated Subcontractor should be indicated in the relevant part of the Bill of Quantities as a particular Provisional Sum with an appropriate brief description. A separate bidding procedure is normally carried out by the Employer to select the specialists, who are then nominated as Subcontractors to the main or prime contractor. To provide an element of competition among the main Bidders (or prime contractors) in respect of any facilities, amenities, attendance, etc., to be provided by the successful Bidder as prime contractor for the use and convenience of the specialist or nominated Subcontractor, each related Provisional Sum should be following by an item in the Bill of Quantities inviting a percentage (to be quoted by the main Bidder) payable on the actual expenditure from the Provisional Sum.

\section{Summary}

The Summary should contain a tabulation of the separate parts of the Bill of Quantities carried forward, with provisional sums for Daywork, for physical (quantity) contingencies, and for price contingencies (upward price adjustment) where applicable.

\author{
NOTE In the case of Lump Sum Contract, use the "Activity Schedule."
}




\section{Sample Bill of Quantities}

\section{A. Preamble}

1. The Bill of Quantities shall be read in conjunction with the Instructions to Bidders, General and Particular Conditions of Contract, Technical Specifications, and Drawings.

2. The quantities given in the Bill of Quantities are estimated and provisional, and are given to provide a common basis for bidding. The basis of payment will be the actual quantities of work ordered and carried out, as measured by the Contractor and verified by the Project Manager and valued at the rates and prices bid in the priced Bill of Quantities, where applicable, and otherwise at such rates and prices as the Project Manager may fix within the terms of the Contract.

3. The rates and prices bid in the priced Bill of Quantities shall, except as otherwise provided under the Contract, include all construction equipment, labor, supervision, materials, erection, maintenance, insurance, profit, taxes, and duties, together with all general risks, liabilities, and obligations set out or implied in the Contract.

4. A rate or price shall be entered against each item in the priced Bill of Quantities, whether quantities are stated or not. The cost of items against which the Contractor has failed to enter a rate or price shall be deemed covered by other rates and prices entered in the Bill of Quantities. The units and rates in figures entered into the Bill of Quantities should be typewritten or if written by hand, must be in print form. Bill of Quantities not presented accordingly may be considered nonresponsive.

5. The whole cost of complying with the provisions of the Contract shall be included in the Items provided in the priced Bill of Quantities, and where no items are provided, the cost shall be deemed to be distributed among the rates and prices entered for the related Items of Work.

6. General directions and descriptions of work and materials are not necessarily repeated or summarized in the Bill of Quantities. References to the relevant sections of the Contract documentation shall be made before entering prices against each item in the priced Bill of Quantities.

7. Provisional Sums included and so designated in the Bill of Quantities shall be expended in whole or in part at the direction and discretion of the Project Manager in accordance with the Conditions of Contract.

8. The method of measurement of completed work for payment shall be in accordance with [insert the name of a standard reference guide, or full details of the methods to be used. The method of measurement should be spelled out precisely in the Preamble to the Bill of Quantities, describing for example the allowances (if any) for timbering in excavation, etc. Many national standard reference guides have been prepared on the subject, and one such guide is the Civil Engineering Standard Method of Measurement of the Institution of Civil Engineers in the United Kingdom.] 
9. Arithmetic errors will be corrected by the Employer as follows:

(a) If there is a discrepancy between the unit price and the total price that is obtained by multiplying the unit price and quantity, the unit price shall prevail and the total price shall be corrected, unless in the opinion of the Employer there is an obvious misplacement of the decimal point in the unit price, in which case the total price as quoted shall govern and the unit price shall be corrected.

(b) If there is an error in a total corresponding to the addition or subtraction of subtotals, the subtotals shall prevail and the total shall be corrected.

(c) If there is a discrepancy between the bid price in the Summary of Bill of Quantities and the bid amount in item (c) of the Letter of Bid, the bid price in the Summary of Bill of Quantities will prevail and the bid amount in item (c) of the Letter of Bid will be corrected.

(d) If there is a discrepancy between words and figures, the amount in words shall prevail, unless the amount expressed in words is related to an arithmetic error, in which case the amount in figures shall prevail subject to (a), (b), and (c) above.

10. Rock is defined as all materials that, in the opinion of the Project Manager, require blasting, or the use of metal wedges and sledgehammers, or the use of compressed air drilling for their removal, and that cannot be extracted by ripping with a tractor of at least 150 brake horsepower with a single, rear-mounted, heavy-duty ripper. 


\section{B. Work Items}

1. The Bill of Quantities usually contains the following part Bills, which have been grouped according to the nature or timing of the work:

Bill No. 1 - General Items;

Bill No. 2 - Earthworks;

Bill No. 3 - Culverts and Bridges;

Bill No. 4 - etc., as required;

Daywork Schedule; and

Summary Bill of Quantities.

2. Bidders shall price the Bill of Quantities in local currency only and shall indicate in the Schedule of Payment Currencies the percentage expected for payment in foreign currency or currencies. The example given illustrates one of the two alternative methods of setting up a Bill of Quantities, in which rates and prices are entered in local currency only, with Bidders stating separately their proportionate requirements in different types and amounts of foreign currencies. The second method is where rates and prices are broken down for each item into local and foreign currency components. The first method is administratively more convenient and hence is more commonly used in Works contracts.

Bill No. 1: General Items

\begin{tabular}{|c|c|c|c|c|c|}
\hline Item no. & Description & Unit & Quantity & Rate & Amount \\
\hline 101 & Performance Bond/Guarantee & sum & item & - & \\
\hline 102 & Insurance of the Works & sum & item & - & \\
\hline 103 & Insurance of Contractor's Equipment & sum & item & - & \\
\hline 104 & Third-Party Insurance & sum & item & - & \\
\hline 105 & Allow for maintenance of Works for 12 months after completion & month & 12 & & \\
\hline 106 & -etc. - & & & & \\
\hline 112 & Provide and equip Project Manager's offices & $\mathrm{nr}$ & 2 & & \\
\hline 113 & $\begin{array}{l}\text { Maintain Project Manager's offices for } 24 \text { months, } \\
\text { including services }\end{array}$ & month & 24 & & \\
\hline 114 & -etc. - & & & & \\
\hline 121 & Provide diversion road & sum & item & - & \\
\hline 122 & Provide for traffic control and maintenance of diversion road & month & 24 & - & \\
\hline 123 & -etc. - & & & & \\
\hline 132 & $\begin{array}{l}\text { Provide for cleaning up the Site on completion } \\
\text { - etc. - }\end{array}$ & sum & item & - & \\
\hline \multicolumn{6}{|c|}{ Total for Bill No. 1} \\
\hline \multicolumn{6}{|c|}{ (carried forward to Summary, p. __ } \\
\hline
\end{tabular}


Bill No. 2: Earthworks

\begin{tabular}{|c|c|c|c|c|c|}
\hline Item no. & Description & Unit & Quantity & Rate & Amount \\
\hline 201 & $\begin{array}{l}\text { Excavate topsoil to maximum depth of } 25 \mathrm{~cm} \text { and } \\
\text { stockpile for reuse, maximum haul distance } 1 \mathrm{~km}\end{array}$ & $\mathrm{~m}^{3}$ & 95,000 & & \\
\hline 202 & $\begin{array}{l}\text { Excavate topsoil to maximum depth of } 25-50 \mathrm{~cm} \text {, and } \\
\text { dispose }\end{array}$ & $\mathrm{m}^{3}$ & 15,000 & & \\
\hline 203 & -etc.- & & & & \\
\hline 206 & $\begin{array}{l}\text { Excavate fill material from cuttings or approved borrow } \\
\text { pits, haul up to } 1 \mathrm{~km} \text {, deposit, shape, and compact to fill }\end{array}$ & $\mathrm{m}^{3}$ & 258,000 & & \\
\hline 207 & Excavate rock in cuttings and dispose, any depth & $\mathrm{m}^{3}$ & 25,000 & & \\
\hline 208 & -etc.- & & & & \\
\hline & & & & & \\
\hline & & & & & \\
\hline \multicolumn{6}{|c|}{ Total for Bill No. 2} \\
\hline \multicolumn{6}{|c|}{ (carried forward to Summary, p. __ } \\
\hline
\end{tabular}

Bill No. 3: Culverts and Bridges

\begin{tabular}{|c|c|c|c|c|c|}
\hline Item no. & Description & Unit & Quantity & Rate & Amount \\
\hline 301 & $\begin{array}{l}\text { Excavate in all materials other than rock from ground level } \\
\text { to underside of foundations, maximum depth of } 5 \mathrm{~m} \text {, and } \\
\text { dispose }\end{array}$ & $\mathrm{m}^{3}$ & 18,500 & & \\
\hline 302 & $\begin{array}{l}\text { Excavate in all materials other than rock, depth of } 5 \mathrm{~m} \text { to } \\
7.5 \mathrm{~m}\end{array}$ & $\mathrm{~m}^{3}$ & 2,500 & & \\
\hline 303 & $\begin{array}{l}\text { Provisional Item } \\
\text { As Item } 302 \text {, depth of } 7.5 \mathrm{~m} \text { to } 10 \mathrm{~m}\end{array}$ & $m^{3}$ & 500 & & \\
\hline 304 & -etc.- & & & & \\
\hline 311 & Concrete class B in abutments & $\mathrm{m}^{3}$ & 18,500 & & \\
\hline 312 & -etc.- & & & & \\
\hline 318 & $\begin{array}{l}\text { Mild steel reinforcement in abutments and piers up to } \\
20 \mathrm{~mm} \text { diameter }\end{array}$ & $\mathrm{t}$ & 370 & & \\
\hline 319 & -etc.- & & & & \\
\hline \multicolumn{6}{|c|}{ Total for Bill No. 3} \\
\hline \multicolumn{6}{|c|}{ (carried forward to Summary, p. _ـ } \\
\hline
\end{tabular}




\section{Daywork Schedule}

\section{NOTES}

A "Daywork Schedule" is commonly found in contracts where the likely incidence of unforeseen work cannot be covered by definitive descriptions and approximate quantities in the Bill of Quantities. The preferred alternative is to value the additional work in accordance with the provisions of Subclause 47.6 and Clause 60 of the General Conditions of Contract. A Daywork Schedule normally has the disadvantage of not being competitive among Bidders, who may therefore load the rates assigned to some or all the items. If a Daywork Schedule is to be included at all in the bidding documents, it is preferable to include nominal quantities against the items most likely to be used, and to carry the sum of the extended amounts forward into the Bid Summary in order to make the basic Schedule of Daywork Rates competitive.

The total amount assigned to such competitive daywork is normally 3\% to 5\% of the estimated base Contract Price and is regarded as a Provisional Sum for contingencies to be expended under the direction and at the discretion of the Project Manager. A limitation on quantity should not apply, and the unit rate quoted should be invariable whatever quantities of work are ordered.

\section{General}

1. Work shall not be executed on a Daywork basis except by written order of the Project Manager. Bidders shall enter basic rates for Daywork items in the Schedules, which rates shall apply to any quantity of Daywork ordered by the Project Manager. Nominal quantities have been indicated against each item of Daywork, and the extended total for Daywork shall be carried forward as a Provisional Sum to the Summary Total Bid Amount. Unless otherwise adjusted, payments for Daywork shall be subject to price adjustment in accordance with the provisions in the Conditions of Contract.

\section{Daywork Labor}

2. In calculating payments due to the Contractor for the execution of Daywork, the hours for labor will be reckoned from the time of arrival of the labor at the job site to execute the particular item of Daywork to the time of return to the original place of departure, but excluding meal breaks and rest periods. Only the time of classes of labor directly doing work ordered by the Project Manager and for which they are competent to perform will be measured. The time of gangers (charge hands) actually doing work with the gangs will also be measured but not the time of foremen or other supervisory personnel.

3. The Contractor shall be entitled to payment in respect of the total time that labor is employed on Daywork, calculated at the basis rates entered by him in the Schedule of Daywork Rates: 1 . Labor. The rates for labor shall be deemed to cover all costs to the Contractor, including (but not limited to) the amount of wages paid to such labor, transportation time, overtime, subsistence allowances, and any sums paid to or on behalf of such labor for social benefits in accordance with (Country of Borrower) law, as well as Contractor's profit; overheads; superintendence; liabilities and insurance and allowance to labor; timekeeping and clerical and office work; the use of consumable stores water, lighting, and power; the use and repair of stagings, scaffolding workshops and stores portable power tools; manual plant and tools; supervision by the Contractor's staff, foremen, and other supervisory personnel; and charges incidental to the foregoing. The rates shall be stated in the local currency, but payments will be made in the following currency proportions:

(i) foreign:__ percent

(ii) local: percent
[The Bidder shall state the percentage in a common foreign currency equivalent required for payment and the exchange rates and official sources used]

[To be stated by Bidder] 


\section{Daywork Materials}

4. The Contractor shall be entitled to payment in respect of materials used for Daywork (except for materials for which the cost is included in the percentage addition to labor costs as detailed heretofore), at the rates entered by him in the Schedule of Daywork Rates: 2. Materials and shall be deemed to include overhead charges and profit as follows:

a) the rates for materials shall be calculated on the basis of the invoiced price, freight, insurance, handling expenses, damage, losses, etc., and shall provide for delivery to store for stockpiling at the Site. The rates shall be stated in local currency but payment will be made in the following currency proportions:

(i) foreign:__ percent [The Bidder shall state the percentage in a common foreign currency equivalent required for payment and the exchange rates and official sources used]

(ii) local: _ percent [To be stated by Bidder]

(b) the cost of hauling materials for use on work ordered to be carried out as daywork from the store or stockpile on the Site to the place where it is to be used will be paid in accordance with the terms for Labor and Constructional Plant in this Schedule.

\section{Daywork Contractor's Equipment}

5. The Contractor shall be entitled to payments in respect of Contractor's Equipment already on Site and employed on Daywork at the basic rental rates entered by him in the Schedule of Daywork Rates: 3. Contractor's Equipment. The said rates shall be deemed to include due and complete allowance for depreciation, interest, indemnity and insurance, repairs, maintenance, supplies, fuel, lubricants, and other consumables, and all overhead profit and administrative costs related to the use of such equipment. The cost of drivers, operators, and assistants will be paid for separately as described under the section on Daywork Labor.

6. In calculating the payment due to the Contractor's Equipment employed on daywork, only the actual number of working hours will be eligible for payment, except that where applicable and agreed with the Project Manager, the traveling time from the part of the Site where the Construction Plant was located when ordered by the Project Manager to be employed on Daywork and the time for return journey thereto shall be included for payment.

7. The basic rental rates for Contractor's Equipment employed on Daywork shall be stated in local currency but payments to the Contractor will be made in currency proportions as follows:

(i) foreign:__ percent_[The Bidder shall state the percentage in a common foreign currency equivalent required for payment and the exchange rates and official sources used]

(ii) local: _ _ percent [To be stated by Bidder] 
Schedule of Daywork Rates: 1. Labor

\begin{tabular}{|c|c|c|c|c|c|}
\hline Item no. & Description & Unit & $\begin{array}{l}\text { Nominal } \\
\text { Quantity }\end{array}$ & Rate & $\begin{array}{c}\text { Extended } \\
\text { Amount }\end{array}$ \\
\hline D100 & Ganger & hour & 500 & & \\
\hline D101 & Laborer & hour & 5,000 & & \\
\hline D102 & Bricklayer & hour & 500 & & \\
\hline D103 & Mason & hour & 500 & & \\
\hline D104 & Carpenter & hour & 500 & & \\
\hline D105 & Steelwork Erector & hour & 500 & & \\
\hline D106 & -etc. - & hour & & & \\
\hline D113 & Driver for vehicle up to 10 tons & hour & 1,000 & & \\
\hline D114 & Operator for excavator, dragline, shovel, or crane & hour & 500 & & \\
\hline D115 & Operator for tractor with dozer blade or ripper & hour & 500 & & \\
\hline D116 & -etc. - & hour & & & \\
\hline & & & & & \\
\hline \multicolumn{6}{|c|}{ Total for Daywork: Labor } \\
\hline \multicolumn{6}{|c|}{ (carried forward to Daywork Summary, p. __ } \\
\hline
\end{tabular}

\section{Schedule of Daywork Rates: 2. Materials}

\begin{tabular}{|c|c|c|c|c|c|}
\hline Item no. & Description & Unit & $\begin{array}{l}\text { Nominal } \\
\text { Quantity }\end{array}$ & Rate & $\begin{array}{l}\text { Extended } \\
\text { Amount }\end{array}$ \\
\hline D201 & Cement, ordinary Portland, or equivalent in bags & $\mathrm{t}$ & 200 & & \\
\hline D202 & $\begin{array}{l}\text { Mild steel reinforcing bar up to } 16 \mathrm{~mm} \text { diameter } \\
\text { to } \mathrm{BS} 4449 \text { or equivalent }\end{array}$ & $\mathrm{t}$ & 100 & & \\
\hline D203 & Fine aggregate for concrete as specified in Clause & $\mathrm{m}^{3}$ & 1,000 & & \\
\hline D204 & -etc. - & & & & \\
\hline D222 & $\begin{array}{l}\text { Gelignite (Nobel Special Gelatine } 60 \% \text {, or equivalent) } \\
\text { including caps, fuse, wire, and requisite accessories }\end{array}$ & $\mathrm{t}$ & 10 & & \\
\hline \multicolumn{6}{|c|}{ Total for Daywork: Materials } \\
\hline \multicolumn{6}{|c|}{ (carried forward to Daywork Summary, p. _ـ } \\
\hline
\end{tabular}


Schedule of Daywork Rates: 3. Contractor's Equipment

\begin{tabular}{|c|c|c|c|c|}
\hline Item no. & Description & $\begin{array}{l}\text { Nominal } \\
\text { Quantity } \\
\text { (hours) }\end{array}$ & $\begin{array}{l}\text { Basic Hourly } \\
\text { Rental Rate }\end{array}$ & $\begin{array}{c}\text { Extended } \\
\text { Amount }\end{array}$ \\
\hline D301 & Excavator, face shovel, or dragline: & & & \\
\hline .1 & Up to and including $1 \mathrm{~m}^{3}$ & 500 & & \\
\hline .2 & Over $1 \mathrm{~m}^{3}$ to $2 \mathrm{~m}^{3}$ & 400 & & \\
\hline .3 & Over $2 \mathrm{~m}^{3}$ & 100 & & \\
\hline D302 & Tractor, including bull or angle dozer: & & & \\
\hline .1 & Up to and including $150 \mathrm{~kW}$ & 500 & & \\
\hline .2 & Over $150 \mathrm{~kW}$ to $200 \mathrm{~kW}$ & 400 & & \\
\hline .3 & Over $200 \mathrm{~kW}$ to $250 \mathrm{~kW}$ & 200 & & \\
\hline D303 & Tractor with ripper: & & & \\
\hline .1 & Up to and including $200 \mathrm{~kW}$ & 400 & & \\
\hline .2 & Over $200 \mathrm{~kW}$ to $250 \mathrm{~kW}$ & 200 & & \\
\hline D304 & -etc.- & & & \\
\hline & & & & \\
\hline \multicolumn{5}{|c|}{ Total for Daywork: Contractor's Equipment } \\
\hline
\end{tabular}

\section{Daywork Summary}

\begin{tabular}{|r|r|r|} 
& $\begin{array}{r}\text { Amount } \\
\text { [local currency }]\end{array}$ & \% Foreign \\
\hline 1. Total for Daywork: Labor & & \\
\hline 2. Total for Daywork: Materials & & \\
\hline 3. Total for Daywork: Contractor's Equipment & & \\
\hline Total for Daywork (Provisional Sum) & & \\
\hline (carried forward to Daywork Summary, p. & & \\
\hline
\end{tabular}


Summary of Specified Provisional Sums

\begin{tabular}{|c|r|r|r|}
\hline Bill no. & Item no. & Description & Amount \\
\hline 1 & & & $1,250,000$ \\
\hline 2 & 2.8 & Supply and install equipment in pumping station & $3,500,000$ \\
\hline 3 & & & Provide for ventilation system in subway tunnel \\
\hline 4 & 4.32 & Total for Specified Provisional Sums & $4,750,000$ \\
\hline etc. & & (carried forward to Grand Summary [B], p. $\longrightarrow$ ) & \\
\hline
\end{tabular}

\section{Summary of Bill of Quantities}

\begin{tabular}{|l|l|l|}
\hline \multicolumn{1}{|c|}{ General Summary } & & \\
\hline Bill No. 1: Preliminary ltems & & \\
\hline Bill No. 2: Earthworks & & \\
\hline Bill No. 3: Drainage Structures & & \\
\hline - etc. - & (A) & \\
\hline Subtotal of Bills & (B) & \\
\hline Total for Daywork & (C) & $4,750,000$ \\
\hline Specified Provisional Sums included in Subtotal of Bills & (D) & \\
\hline Total of Bills plus Provisional Sums (A + B + C) & (E) & (F) \\
\hline Add Provisional Sum for Contingency & & \\
\hline Bid Price (D + E) to be carried forward to Letter of Bid & & \\
\hline
\end{tabular}

1. All provisional sums are to be expended in whole or in part at the direction and discretion of the project manager in accordance with the Conditions of Contract.

2. The amount for (C) Specified Provisional Sums included in Subtotal of Bills, if any, is to be entered by the employer, which is the total amount from the table, Summary of Specified Provisional Sums. Alternatively, the employer may use only (E) Provisional Sum for Contingency described below.

3. The amount for (B) Daywork needs to be included only when the Daywork Schedule is made competitive by the introduction of nominal quantities of work to be extended at the rates quoted. If not competitive, it should be included in (E) Provisional Sum for Contingencies and excluded from evaluation.

4. For (E) Provisional Sum for Contingency, covering unforeseen physical quantities of work, it is recommended to insert a predetermined percentage to provide for unforeseen physical quantities of work (usually $5 \%-15 \%$ of base cost, that is of the subtotal of bills) and, if included in the contract, for price escalation adjustments (commonly $6 \%-12 \%$ per annum on estimated annual payments). The resulting total bid price is then a more realistic estimated final contract value for the purposes of budgetary approval. As an alternative to the percentage addition for contingencies, a fixed amount can be predetermined by the employer, based on the estimated contract amount, and inserted as a common figure in the "Amount" column.

5. For evaluation purposes, daywork, if priced competitively, will be included but provisional sums will be excluded.

6. For (F) the Bid Price is inclusive of all Environmental, Health and Safety management and compliance cost.

7. Option to enter provisional sum by the Employer for additional Environmental outcomes. [Delete if not applicable.] 


\section{Bid Security}

\section{Bank Guarantee}

[Bank's name, and address of issuing branch or office $]^{4}$

Beneficiary:

[Name and address of the Employer]

\section{Date:}

\section{Bid Security No.:}

We have been informed that [name of the bidder] (hereinafter called "the Bidder") has submitted to you its bid dated [please specify] (hereinafter called "the Bid") for the execution of [name of contract] under Invitation for Bids No. [please specify] ("the IFB").

Furthermore, we understand that, according to your conditions, bids must be supported by a bid guarantee.

At the request of the Bidder, we [name of bank] hereby irrevocably undertake to pay you any sum or sums not exceeding in total an amount of [amount in words] [amount in figures] upon receipt by us of your first demand in writing accompanied by a written statement stating that the Bidder is in breach of its obligation(s) under the bid conditions, because the Bidder

(a) has withdrawn its Bid during the period of bid validity specified by the Bidder in the Letter of Bid; or

(b) does not accept the correction of errors in accordance with the Instructions to Bidders (hereinafter "the ITB"); or

(c) having been notified of the acceptance of its Bid by the Employer during the period of bid validity, (i) fails or refuses to execute the Contract Agreement, or (ii) fails or refuses to furnish the performance security, in accordance with the ITB, or (iii) fails or refuses to furnish the domestic preference security, if required.

This guarantee will expire (a) if the Bidder is the successful Bidder, upon our receipt of copies of the Contract Agreement signed by the Bidder and the Performance Security issued to you upon the instruction of the Bidder; or (b) if the Bidder is not the successful Bidder, upon the earlier of (i) our receipt of a copy of your notification to the Bidder of the name of the successful Bidder, or (ii) 28 days after the expiration of the Bidder's bid.

Consequently, any demand for payment under this guarantee must be received by us at the office indicated above on or before that date.

This guarantee is subject to the Uniform Rules for Demand Guarantees (URDG) 2010 Revisions, ICC Publication No. $758 .^{5}$

[Authorized signature(s) and bank's seal (where appropriate)]

All italicized text is for use in preparing this form and shall be deleted from the final document.

Or the employer may use "Uniform Rules for Demand Guarantees (URDG), ICC Publication No. 458 as appropriate. 


\section{Bid-Securing Declaration}

Date: [insert date (as day, month and year)]

Bid No.: [insert number of bidding process]

Alternative No.: [insert identification number if this is a bid for an alternative]

To: [insert complete name of the Employer]

We, the undersigned, declare that:

We understand that, according to your conditions, Bids must be supported by a Bid-Securing Declaration.

We accept that we will automatically be suspended from being eligible for bidding in any contract with the Borrower for the period of time of [insert the number of years as indicated in ITB 19.2 of the BDS] starting on the date that we receive a notification from the Employer, if we are in breach of our obligation(s) under the bid conditions, because we

(a) have withdrawn our Bid during the period of bid validity specified in the Letter of Bid; or

(b) do not accept the correction of errors in accordance with the Instruction to Bidders (hereinafter "the ITB"); or

(c) having been notified of the acceptance of our Bid by the Employer during the period of bid validity, (i) fail or refuse to execute the Contract, if required; (ii) fail or refuse to furnish the Performance Security, in accordance with the ITB; or (iii) fail or refuse to furnish the Domestic Preference Security, if required.

We understand that this Bid-Securing Declaration shall expire if we are not the successful Bidder, upon the earlier of (i) our receipt of your notification to us of the name of the successful Bidder; or (ii) 28 days after the expiration of our Bid.

Signed: [insert signature of person whose name and capacity are shown]

In the capacity of [insert legal capacity of person signing the Bid-Securing Declaration]

Name: [insert complete name of person signing the Bid-Securing Declaration]

Duly authorized to sign the bid for and on behalf of [insert complete name of the Bidder]

Dated on day of

Corporate Seal [where appropriate] 


\section{Affiliate Company Guarantee}

Name of Contract/Contract No.:

Name and address of Employer:

[together with successors and assigns].

We have been informed that [name of Contractor] (hereinafter called the "Contractor") is submitting an offer for the above-referenced Contract in response to your invitation, and that the conditions of your invitation require its offer to be supported by an affiliate company guarantee.

In consideration of you, the Employer, awarding the Contract to the Contractor, we [name of affiliated company] irrevocably and unconditionally guarantee to you, as a primary obligation, that (i) throughout the duration of the Contract, we will make available to the Contractor our financial, technical capacity, expertise and resources required for the Contractor's satisfactory performance of the Contract; and (ii) we are fully committed, along with the Contractor, to ensuring a satisfactory performance of the Contract.

If the Contractor fails to so perform its obligations and liabilities and comply with the Contract, we will indemnify the Employer against and from all damages, losses and expenses (including legal fees and expenses) which arise from any such failure for which the Contractor is liable to the Employer under the Contract.

This guarantee shall come into full force and effect when the Contract comes into full force and effect. If the Contract does not come into full force and effect within a year of the date of this guarantee, or if you demonstrate that you do not intend to enter into the Contract with the Contractor, this guarantee shall be void and ineffective. This guarantee shall continue in full force and effect until all the Contractor's obligations and liabilities under the Contract have been discharged, when this guarantee shall expire and shall be returned to us, and our liability hereunder shall be discharged absolutely.

This guarantee shall apply and be supplemental to the Contract as amended or varied by the Employer and the Contractor from time to time. We hereby authorize them to agree on any such amendment or variation, the due performance of which and compliance with which by the Contractor are likewise guaranteed hereunder. Our obligations and liabilities under this guarantee shall not be discharged by any allowance of time or other indulgence whatsoever by the Employer to the Contractor, or by any variation or suspension of the works to be executed under the Contract, or by any amendments to the Contract or to the constitution of the Contractor or the Employer, or by any other matters, whether with or without our knowledge or consent.

This guarantee shall be governed by the law of the same country (or other jurisdiction) that governs the Contract and any dispute under this guarantee shall be finally settled under the [Rules or Arbitration provided in the Contract]. We confirm that the benefit of this guarantee may be assigned subject only to the provisions for assignment of the Contract.

Signed by:

(signature)

(name)

..............................

(position in parent/subsidiary company)
Signed by:

(signature)

(name)

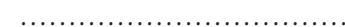

(position in parent/subsidiary company)

\section{NOTE}

If permitted in accordance with ITB 38.2 of the BDS, the Bidder shall provide the Affiliate Company Guarantee Form filled out and signed by each subsidiary, parent entity, or affiliate that the Bidder submits for consideration of the Employer in determining its qualifications.

Date: 


\section{Technical Proposal}

\section{Personnel}

\section{Form PER - 1: Proposed Personnel}

Bidder should provide the details of the proposed personnel and their experience record in the relevant Information Forms below for each candidate:

\begin{tabular}{|l|l|}
\hline \multirow{2}{*}{1.} & Title of position \\
\cline { 2 - 2 } & Name \\
\hline \multirow{2}{*}{ 3. } & Title of position \\
\cline { 2 - 2 } & Name \\
\cline { 2 - 2 } & Title of position \\
\hline \multirow{2}{*}{4.} & Name \\
\cline { 2 - 2 } & Title of position \\
\hline \multirow{2}{*}{5.} & Title of position \\
\cline { 2 - 2 } & Name \\
\hline 6. & Title of position \\
\cline { 2 - 2 } & Name \\
\hline etc. & Title of position \\
\cline { 2 - 2 } & Name \\
\hline
\end{tabular}

Note: All titles of positions will be as listed in Section 6 (Employer's Requirements). 


\section{Form PER - 2: Resumé of Proposed Personnel}

The Bidder shall provide all the information requested below. Use one form for each position.

\begin{tabular}{|c|c|c|}
\hline Position & & \\
\hline \multirow{5}{*}{$\begin{array}{l}\text { Personnel } \\
\text { information }\end{array}$} & Full Legal Name & Date of birth \\
\hline & Known as & Place of Birth \\
\hline & Nationality & Citizenship \\
\hline & Type of Government ID & ID number \\
\hline & Attach a copy of ID to this form & \\
\hline \multirow{5}{*}{$\begin{array}{l}\text { Present } \\
\text { employment }\end{array}$} & \multicolumn{2}{|l|}{ Name of employer } \\
\hline & \multicolumn{2}{|l|}{ Address of employer } \\
\hline & Telephone & Contact (manager/personnel officer) \\
\hline & Fax & E-mail \\
\hline & Job title & Years with present employer \\
\hline
\end{tabular}

Summarize professional experience in reverse chronological order. Indicate particular technical and managerial experience relevant to the project.

\begin{tabular}{|l|l|l|}
\multicolumn{1}{|c|}{ From } & To & Company/Project/Position/Relevant Technical and Management Experience \\
\hline & & \\
\hline & & \\
\hline & & \\
\hline & & \\
\hline & & \\
\hline & & \\
\hline & & \\
\hline
\end{tabular}




\section{Equipment}

\section{Form EQU: Equipment}

The Bidder shall provide adequate information and details to demonstrate clearly that it has the capability to meet the equipment requirements indicated in Section 6 (Employer's Requirements), using the Forms below. A separate Form shall be prepared for each item of equipment listed, or for alternative equipment proposed by the Bidder.

\begin{tabular}{|c|c|c|}
\hline \multicolumn{3}{|c|}{ Item of Equipment } \\
\hline \multirow{2}{*}{$\begin{array}{l}\text { Equipment } \\
\text { Information }\end{array}$} & Name of manufacturer & Model and power rating \\
\hline & Capacity & Year of manufacture \\
\hline \multirow{2}{*}{$\begin{array}{l}\text { Current } \\
\text { Status }\end{array}$} & \multicolumn{2}{|l|}{ Current location } \\
\hline & \multicolumn{2}{|l|}{ Details of current commitments } \\
\hline \multirow[t]{2}{*}{ Source } & \multicolumn{2}{|l|}{ Indicate source of the equipment } \\
\hline & $\square$ Rented & $\square$ Specially manufactured \\
\hline
\end{tabular}

Omit the following information for equipment owned by the Bidder.

\begin{tabular}{|l|l|l|}
\hline \multirow{3}{*}{ Owner } & \multicolumn{2}{|l|}{ Name of owner } \\
\cline { 2 - 3 } & \multicolumn{2}{|l|}{ Address of owner } \\
\cline { 2 - 3 } & Telephone & Contact name and title \\
\cline { 2 - 3 } & Fax & Telex \\
\hline Agreements & Details of rental/lease/manufacture agreements specific to the project \\
\hline
\end{tabular}


Site Organization

Method Statement

\section{Mobilization Schedule}

Please reflect the no-objection request and approval step for Site Specific Environmental, Health and Safety Management Plan as per Contract Conditions in the Mobilization Schedule.

\section{Construction Schedule}

The construction schedule shall include the following key milestones:

\section{Environmental, Health and Safety Management Plan (EHSMP)}

The Bidder shall submit an outline Environmental, Health and Safety Management Plan (EHSMP) commensurate with the risks and impacts of the proposed works and activities. These strategies and plans shall describe in detail the actions, materials, equipment, management processes etc. that will be implemented by the Contractor, and its subcontractors.

In developing these strategies and plans, the Bidder shall have regard to the EHS provisions of the contract and EHS risks including those as may be more fully described in Section 6 (Employer's Requirements).

\section{NOTE}

The Employer shall assess whether proposed site organization, method statement, mobilization, schedule, construction schedule and environmental, health and safety management plan described in Section 4 (Bidding Forms) are presented in consistent manner and comply with requirements stipulated in Section 6 (Employer's Requirements) without material deviation, reservation, or omission. 
Environmental, Health and Safety Code of Conduct

Environmental, Health and Safety Code of Conduct for Contractor's Personnel Form

\section{NOTE TO EMPLOYER}

The following minimum requirements shall not be modified. The Employer may add additional requirements to address identified issues, informed by relevant environmental, health and safety assessment.

Delete this Box prior to issuance of the bidding documents.

\section{NOTE TO BIDDER}

The minimum content of the EHS Code of Conduct form as set out by the Employer shall not be substantially modified. However, the Bidder may add requirements as appropriate, including to take into account Contract-specific issues/risks.

The Bidder shall initial and submit the EHS Code of Conduct form as part of its bid.

\section{ENVIRONMENTAL, HEALTH AND SAFETY CODE OF CONDUCT FOR CONTRACTOR'S PERSONNEL}

We are the Contractor, [enter name of Contractor]. We have signed a contract with [enter name of Employer] for [enter description of the Works]. These Works will be carried out at [enter the Site and other locations where the Works will be carried out]. Our contract requires us to implement measures to address environmental, health and safety risks related to the Works.

This EHS Code of Conduct is part of our measures to deal with environmental, health and safety risks related to the Works. It applies to all our staff, labourers and other employees at the Works Site or other places where the Works are being carried out. It also applies to the personnel of each subcontractor and any other personnel assisting us in the execution of the Works. All such persons are referred to as "Contractor's Personnel" and are subject to this EHS Code of Conduct.

This EHS Code of Conduct identifies the behavior that we require from all Contractor's Personnel.

Our workplace is an environment where unsafe, offensive, abusive or violent behavior will not be tolerated and where all persons should feel comfortable raising issues or concerns without fear of retaliation.

\section{Required Conduct}

\section{Contractor's Personnel shall:}

1. carry out his/her duties competently and diligently;

2. comply with this EHS Code of Conduct and all applicable laws, regulations and other requirements, including requirements to protect the health, safety and well-being of other Contractor's Personnel and any other person; 
3. maintain a safe working environment including by:

a. ensuring that workplaces, machinery, equipment and processes under each person's control are safe and without risk to health;

b. $\quad$ wearing required personal protective equipment;

c. using appropriate measures relating to chemical, physical and biological substances and agents; and

d. following applicable emergency operating procedures.

4. report work situations that he/she believes are not safe or healthy and remove himself/herself from a work situation which he/she reasonably believes presents an imminent and serious danger to his/her life or health;

5. treat other people with respect, and not discriminate against specific groups such as women, people with disabilities, migrant workers or children;

6. report violations of this EHS Code of Conduct; and

7. not retaliate against any person who reports violations of this EHS Code of Conduct, whether to us or the Employer, or who makes use of the grievance mechanism for Contractor's Personnel or the project's Grievance Redress Mechanism.

\section{Raising Concerns}

If any person observes behavior that he/she believes may represent a violation of this EHS Code of Conduct, or that otherwise concerns him/her, he/she should raise the issue promptly. This can be do done by call [ ] to reach the Contractor's hotline (if any) and leave a message.

The person's identity will be kept confidential, unless reporting of allegations is mandated by the country law. Anonymous complaints or allegations may also be submitted and will be given all due and appropriate consideration. We take seriously all reports of possible misconduct and will investigate and take appropriate action. We will provide warm referrals to service providers that may help support the person who experienced the alleged incident, as appropriate.

\section{Consequences of Violating the Environmental, Health and Safety Code of Conduct}

Any violation of this EHS Code of Conduct by Contractor's Personnel may result in serious consequences, up to and including termination and possible referral to legal authorities. 


\section{For Contractor's Personnel:}

I have received a copy of this EHS Code of Conduct written in a language that I comprehend. I understand that if I have any questions about this EHS Code of Conduct, I can contact [enter name of Contractor's contact person(s) with relevant experience] requesting an explanation.

Name of Contractor's Personnel: [insert name]

Signature:

Date: $[$ day/month/year $]$ :

Countersignature of authorized representative of the Contractor:

Signature:

Date: $[$ day/month/year]: 


\section{Bidder's Qualification}

To establish its qualifications to perform the contract in accordance with Section 3 (Evaluation and Qualification Criteria) the Bidder shall provide the following information requested in the corresponding Information Sheets. 
Form ELI - 1: Bidder's Information Sheet

\begin{tabular}{|c|c|c|c|}
\hline \multicolumn{4}{|c|}{ Bidder's Information } \\
\hline & & $\begin{array}{l}\text { Information of the } \\
\text { Bidder }\end{array}$ & $\begin{array}{l}\text { If the Bidder is a subsidiary or branch, } \\
\text { information of any parent company/companies }\end{array}$ \\
\hline \multirow{2}{*}{ Names } & Full legal name(s) & & \\
\hline & $\begin{array}{l}\text { Full trading } \\
\text { name(s) (if any) }\end{array}$ & & \\
\hline \multirow{3}{*}{ Addresses } & $\begin{array}{l}\text { Registered } \\
\text { address(es) }\end{array}$ & & \\
\hline & $\begin{array}{l}\text { Trading } \\
\text { address(es) }\end{array}$ & & \\
\hline & $\begin{array}{l}\text { Postal address(es) } \\
\text { (if different from } \\
\text { trading address) }\end{array}$ & & \\
\hline \multicolumn{2}{|c|}{ Type of organization } & & \\
\hline \multicolumn{2}{|c|}{$\begin{array}{l}\text { Country of constitution/ } \\
\text { incorporation/registration }\end{array}$} & & \\
\hline \multicolumn{2}{|c|}{$\begin{array}{l}\text { Year of constitution/ } \\
\text { incorporation/registration }\end{array}$} & & \\
\hline \multicolumn{2}{|c|}{ Corporate or registration number } & & \\
\hline \multicolumn{2}{|c|}{$\begin{array}{l}\text { In case of a Joint Venture, legal } \\
\text { name of each partner }\end{array}$} & & \\
\hline \multicolumn{2}{|c|}{$\begin{array}{l}\text { Bidder's authorized } \\
\text { representative } \\
\text { (name, address, telephone } \\
\text { number(s), fax number(s), } \\
\text { e-mail address) }\end{array}$} & & \\
\hline \multicolumn{4}{|c|}{$\begin{array}{l}\text { 1. In case of a single entity, articles of incorporation or constitution and company incorporation/registration of } \\
\text { the legal entity named above, in accordance with ITB } 4.1 \text { and ITB } 4.2 \text {. } \\
\text { 2. Authorization to represent the firm or Joint Venture named above, in accordance with ITB } 20.2 \text {. } \\
\text { 3. In case of a Joint Venture, a letter of intent to form a Joint Venture or Joint Venture agreement, in } \\
\text { accordance with ITB 4.1. } \\
\text { 4. In case of a government-owned enterprise, any additional documents not covered under } 1 \text { above required to } \\
\text { comply with ITB 4.5. }\end{array}$} \\
\hline
\end{tabular}


Form ELI - 2: Joint Venture Information Sheet

Each partner of the Joint Venture and Specialist Subcontractor must fill out this form separately.

\section{Joint Venture/Specialist Subcontractor Information}

Bidder's legal name

\begin{tabular}{|c|c|c|c|}
\hline & & $\begin{array}{l}\text { Information of Joint } \\
\text { Venture Partner or } \\
\text { Specialist Subcontractor }\end{array}$ & $\begin{array}{l}\text { If any Joint Venture Partner or Specialist } \\
\text { Subcontractor is a subsidiary or branch, } \\
\text { information of any parent company/companies }\end{array}$ \\
\hline & Full legal name(s) & & \\
\hline Tamites & $\begin{array}{l}\text { Full trading } \\
\text { name(s) (if any) }\end{array}$ & & \\
\hline & $\begin{array}{l}\text { Registered } \\
\text { address(es) }\end{array}$ & & \\
\hline Addresses & $\begin{array}{l}\text { Trading } \\
\text { address(es) }\end{array}$ & & \\
\hline & $\begin{array}{l}\text { Postal address(es) } \\
\text { (if different from } \\
\text { trading address) }\end{array}$ & & \\
\hline Type of org & ization & & \\
\hline $\begin{array}{l}\text { Country of } \\
\text { incorporati }\end{array}$ & $\begin{array}{l}\text { nstitution/ } \\
\text { /registration }\end{array}$ & & \\
\hline $\begin{array}{l}\text { Year of con } \\
\text { incorporati }\end{array}$ & $\begin{array}{l}\text { tution/ } \\
\text { /registration }\end{array}$ & & \\
\hline Corporate & registration number & & \\
\hline $\begin{array}{l}\text { Joint Vent } \\
\text { Specialist } S \\
\text { authorized } \\
\text { informatior } \\
\text { (name, add } \\
\text { number(s), } \\
\text { e-mail addr }\end{array}$ & $\begin{array}{l}\text { Partner's or } \\
\text { contractor's } \\
\text { oresentative } \\
\text { s, telephone } \\
\text { number(s), }\end{array}$ & & \\
\hline
\end{tabular}

\section{Attached are copies of the following documents.}

1. Articles of incorporation or constitution and company incorporation/registration of the legal entity named above, in accordance with ITB 4.1 and ITB 4.2.

2. Authorization to represent the firm named above, in accordance with ITB 20.2.

3. In the case of a government-owned enterprise, documents establishing legal and financial autonomy and compliance with commercial law, in accordance with ITB 4.5. 


\section{Form CON - 1: Historical Contract Nonperformance}

Each Bidder must fill out this form in accordance with Criteria 2.2.1 and 2.2.3 of Section 3 (Evaluation and Qualification Criteria) to describe any history of nonperforming contracts and pending litigation or arbitration formally commenced against it.

In case of a Joint Venture, each Joint Venture Partner must fill out this form separately and provide the Joint Venture Partner's name:

Joint Venture Partner:

\section{Table 1: History of Nonperforming Contracts}

\section{Choose one of the following:}

$\square \quad$ No nonperforming contracts.

$\square$ Below is a description of nonperforming contracts involving the Bidder (or each Joint Venture member if Bidder is a Joint Venture).

\begin{tabular}{|c|c|c|c|}
\hline Year & Description & $\begin{array}{c}\text { Amount of } \\
\text { Nonperformed Portion } \\
\text { of Contract } \\
\text { (\$ equivalent) }\end{array}$ & $\begin{array}{c}\text { Total Contract Amount } \\
\text { (\$ equivalent) }\end{array}$ \\
\hline [insert year] & $\begin{array}{l}\text { Contract Identification: [indicate complete } \\
\text { contract name/number, and any other identification] } \\
\text { Name of Employer: [insert full name] } \\
\text { Address of Employer: [insert street/city/country] } \\
\text { Reason(s) for nonperformance: [indicate main } \\
\text { reason(s)] }\end{array}$ & [insert amount] & [insert amount] \\
\hline
\end{tabular}

\section{Table 2: Pending Litigation and Arbitration}

\section{Choose one of the following:}

$\square$ No pending litigation, arbitration or any other material events impacting the net worth and/or liquidity of the bidder.

$\square$ Below is a description of all pending litigation, arbitration involving the Bidder or any other material events impacting the net worth and/or liquidity of the bidder (or each Joint Venture partner if Bidder is a Joint Venture). 


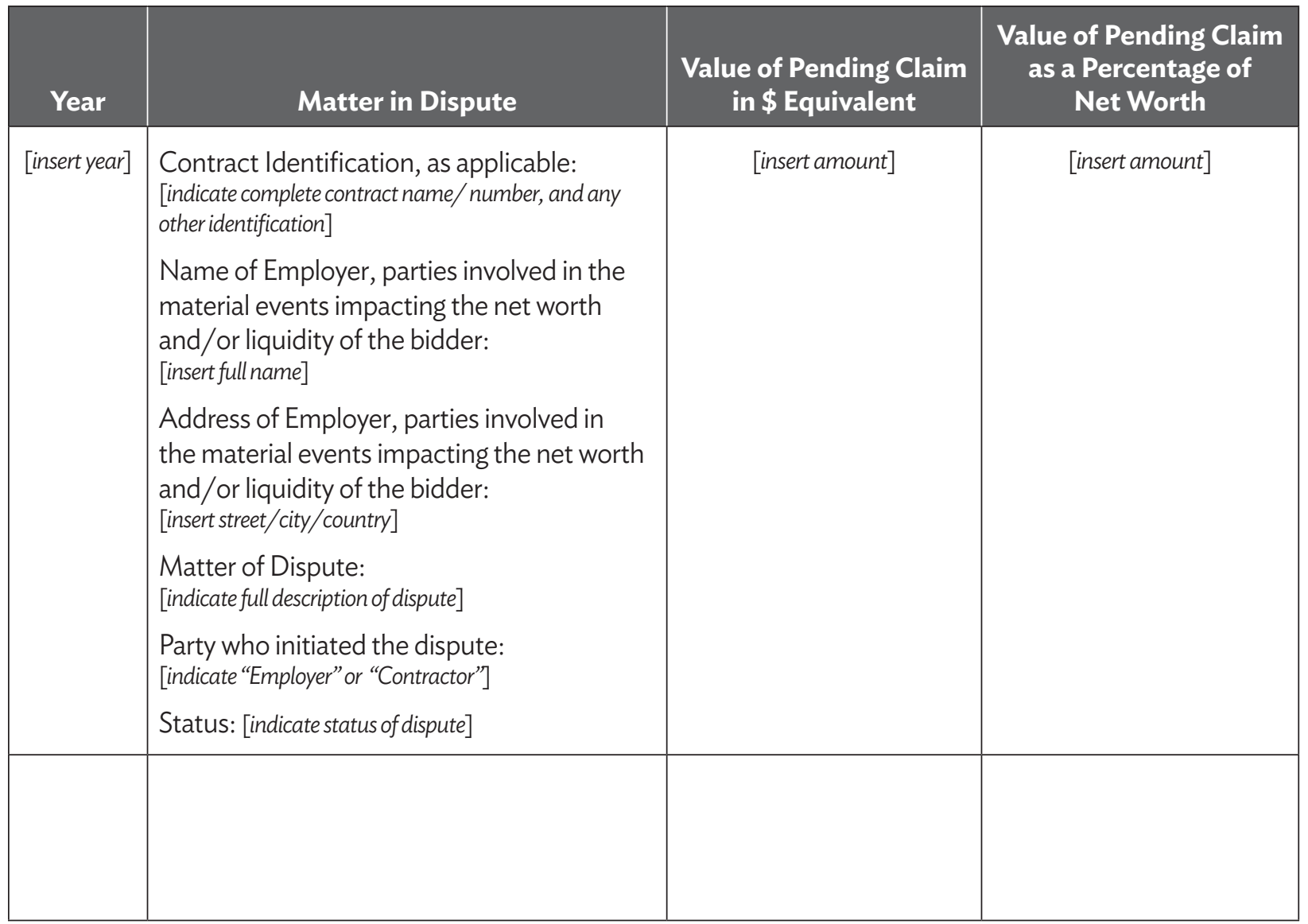
is applicable. 


\section{Form CON - 2: EHS Performance Declaration}

Each Bidder must fill out this form in accordance with Criterion 2.2.4 of Section 3 (Evaluation and Qualification Criteria).

In case of a Joint Venture, each Joint Venture Partner must fill out this form separately and provide the Joint Venture Partner's name:

Joint Venture Partner:

In case of a Specialist Subcontractors, each Specialist Subcontractor must fill out this form and provide the Specialist Subcontractor's name:

Specialist Subcontractor:

\section{Environmental and Health and Safety Performance Declaration in accordance with Section 3} (Evaluation and Qualification Criteria)

$\square$ No suspension or termination of contract: An employer has not suspended or terminated a contract and/or called the performance security for a contract for reasons related to Environmental or Health and Safety performance since the date specified in Section 3 (Evaluation and Qualification Criteria), Criterion 2.5.

$\square$ Declaration of suspension or termination of contract: : The following contract(s) has/have been suspended or terminated and/or Performance Security called by an employer(s) for reasons related to Environmental or Health and Safety performance since the date specified in Section 3 (Evaluation and Qualification Criteria), Criterion 2.5. Details are described below:

$\square$ Declaration of request for replacement of Key Environment, Health and Safety Personnel: The following contract(s) has/have experienced a request by the Employer to replace Environmental, Health and Safety Personnel for reasons related to Environmental or Health and Safety performance since the date specified in Section 3 (Evaluation and Qualification Criteria), Criterion 2.5. Details are described below:

$\square$ Declaration of past fatality resulted from EHS issues on site: The following contract(s) has/have experienced a fatality resulted from EHS issues on site since the date specified in Section 3 (Evaluation and Qualification Criteria), Criterion 2.5. Details are described below:

\begin{tabular}{|c|c|c|c|}
\hline Year & $\begin{array}{c}\text { Suspended or } \\
\text { terminated portion } \\
\text { of contract }\end{array}$ & Contract Identification & $\begin{array}{l}\text { Total Contract Amount } \\
\text { (current value, } \\
\text { currency, exchange rate } \\
\text { and US\$ equivalent) }\end{array}$ \\
\hline [insert year] & $\begin{array}{l}\text { [insert amount } \\
\text { and percentage] }\end{array}$ & $\begin{array}{l}\text { Contract Identification: [indicate complete contract } \\
\text { name/ number, and any other identification] } \\
\text { Name of Employer: [insert full name] } \\
\text { Address of Employer: [insert street/city/country] } \\
\text { Reason(s) for suspension or termination: [indicate } \\
\text { main reason(s) e.g. discharge over environmental limit, } \\
\text { workers did not have required health and safety permits } \\
\text { to undertake high risk work, work carried out was not } \\
\text { adhered to approved construction methodology and } \\
\text { quality control plan.] }\end{array}$ & [insert amount] \\
\hline [insert year] & $\begin{array}{l}\text { [insert amount } \\
\text { and percentage] }\end{array}$ & $\begin{array}{l}\text { Contract Identification: [indicate complete contract } \\
\text { name/ number, and any other identification] } \\
\text { Name of Employer: [insert full name] } \\
\text { Address of Employer: [insert street/city/country] } \\
\text { Reason(s) for suspension or termination: [indicate } \\
\text { main reason(s)] }\end{array}$ & [insert amount] \\
\hline$\ldots$ & $\cdots$ & [list all applicable contracts] & \\
\hline
\end{tabular}


Performance Security called by an employer(s) for reasons related to EHS performance

\begin{tabular}{|c|c|c|}
\hline Year & Contract Identification & $\begin{array}{l}\text { Total Contract Amount } \\
\text { (current value, currency, } \\
\text { exchange rate and US\$ } \\
\text { equivalent) }\end{array}$ \\
\hline [insert year] & $\begin{array}{l}\text { Contract Identification: [indicate complete contract name/ number, and any } \\
\text { other identification] } \\
\text { Name of Employer: [insert full name] } \\
\text { Address of Employer: [insert street/city/country] } \\
\text { Reason(s) for calling of performance security: [indicate main reason(s) } \\
\text { e.g. discharge over environmental limit, workers did not have required health and } \\
\text { safety permits to undertake high risk work, work carried out was not adhered to } \\
\text { approved construction methodology and quality control plan.] }\end{array}$ & [insert amount] \\
\hline
\end{tabular}

Key EHS personnel replacement requested by the Employer for reasons related to EHS performance

\begin{tabular}{|c|l|l|}
\hline \multicolumn{1}{|c|}{ Year } & \multicolumn{1}{c|}{ Contract Identificationand Reasons } & $\begin{array}{c}\text { Personnel replacement } \\
\text { action and results }\end{array}$ \\
\hline [insert year] & $\begin{array}{l}\text { Contract Identification: [indicate complete contract name/ number, and any } \\
\text { other identification] } \\
\text { Name of Employer: [insert full name] } \\
\text { Address of Employer: [insert street/city/country] } \\
\text { Reason(s) for requesting for replacement: [indicate main reason(s) }\end{array}$ & [insert description] \\
\hline & & \\
\hline
\end{tabular}

\section{Fatality due to EHS issues on Site}

\begin{tabular}{|c|l|l|}
\hline \multicolumn{1}{|c|}{ Year } & \multicolumn{1}{c|}{\begin{tabular}{c}
\multicolumn{1}{c}{ Contract Identification } \\
[insert year]
\end{tabular}} & $\begin{array}{l}\text { Follow-on actions taken } \\
\text { by the contractor } \\
\text { other identification] } \\
\text { Name of Employer: [insert full name] } \\
\text { Address of Employer: [insert street/city/country] } \\
\text { Description of fatality event: } \\
\text { Causation: }\end{array}$ \\
\hline & & \\
\hline
\end{tabular}




\section{Form FIN - 1: Historical Financial Performance}

Each Bidder must fill out this form.

In case of a Joint Venture, each Joint Venture Partner must fill out this form separately and provide the Joint Venture Partner's name:

Joint Venture Partner:

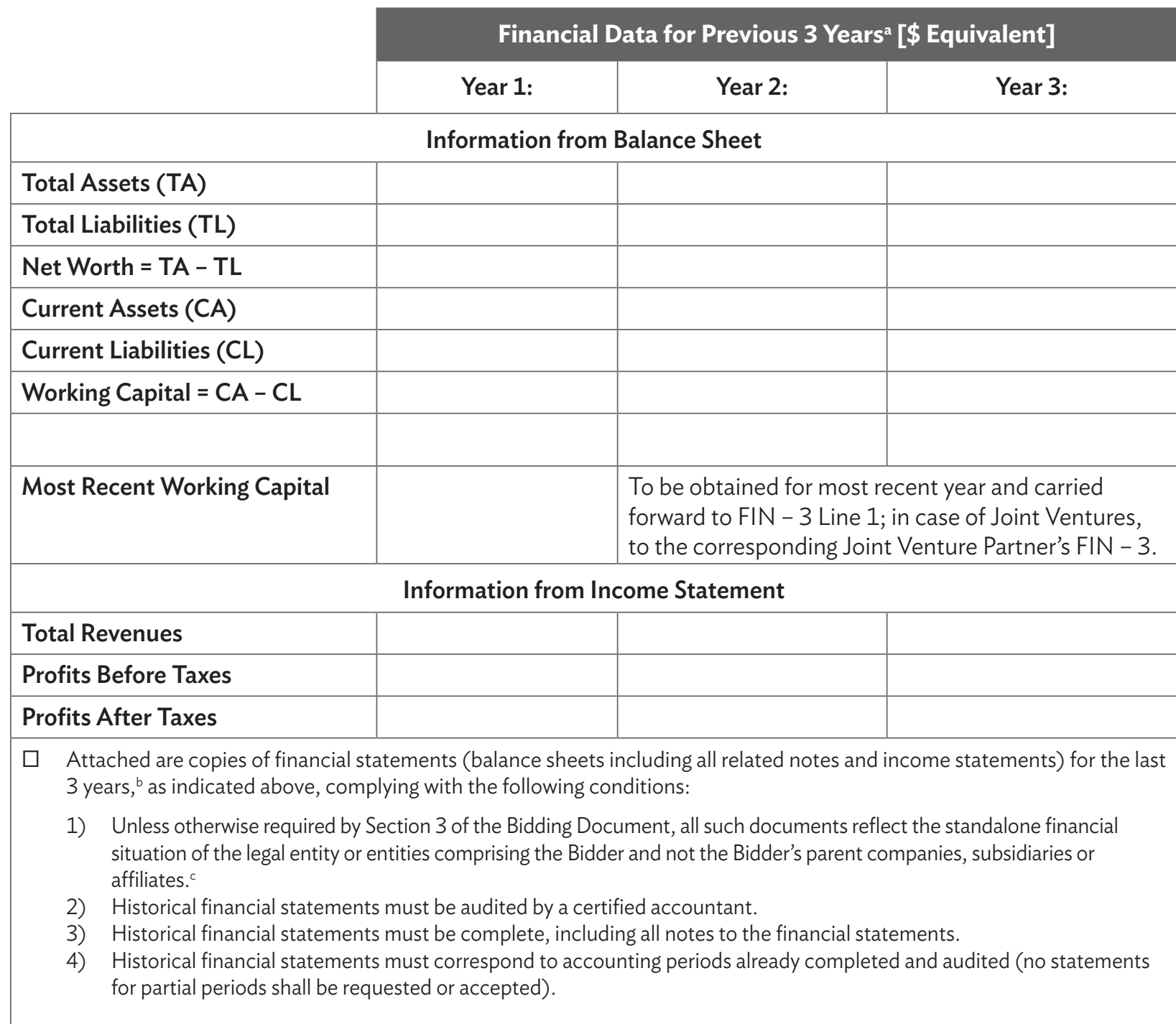

a If the time period indicated under Criterion 2.3.1 of Section 3 (Evaluation and Qualification Criteria) is either 4 or 5 years, then the table columns above should be expanded accordingly.

b The time period stated here should be the same as the time period indicated under Criterion 2.3.1 of Section 3 (Evaluation and Qualification Criteria).

c When financial qualifications of Bidder's parent companies, subsidiaries, or affiliates are permitted in accordance with ITB 38.2 of Section 2, replace the text of condition 1 with "As required by Section 3 of the Bidding Documents, all such documents reflect the standalone financial situation of the legal entity or entities comprising the Bidder, as well as standalone financial situation of such Bidder's parent companies, subsidiaries, or affiliates which are proposed by the Bidder for Criteria 2.3 Financial Situation in Section 3 for consideration of the Employer in determining its qualifications." 


\section{Form FIN - 2: Average Annual Construction Turnover}

Each Bidder must fill out this form.

The information supplied should be the Annual Turnover of the Bidder or each partner of a Joint Venture for the total certified payments received from the clients for contracts in progress or completed, converted to US dollars at the rate of exchange at the end of the period reported.

In case of a Joint Venture, each Joint Venture Partner must fill out this form separately and provide the Joint Venture Partner's name:

Joint Venture Partner:

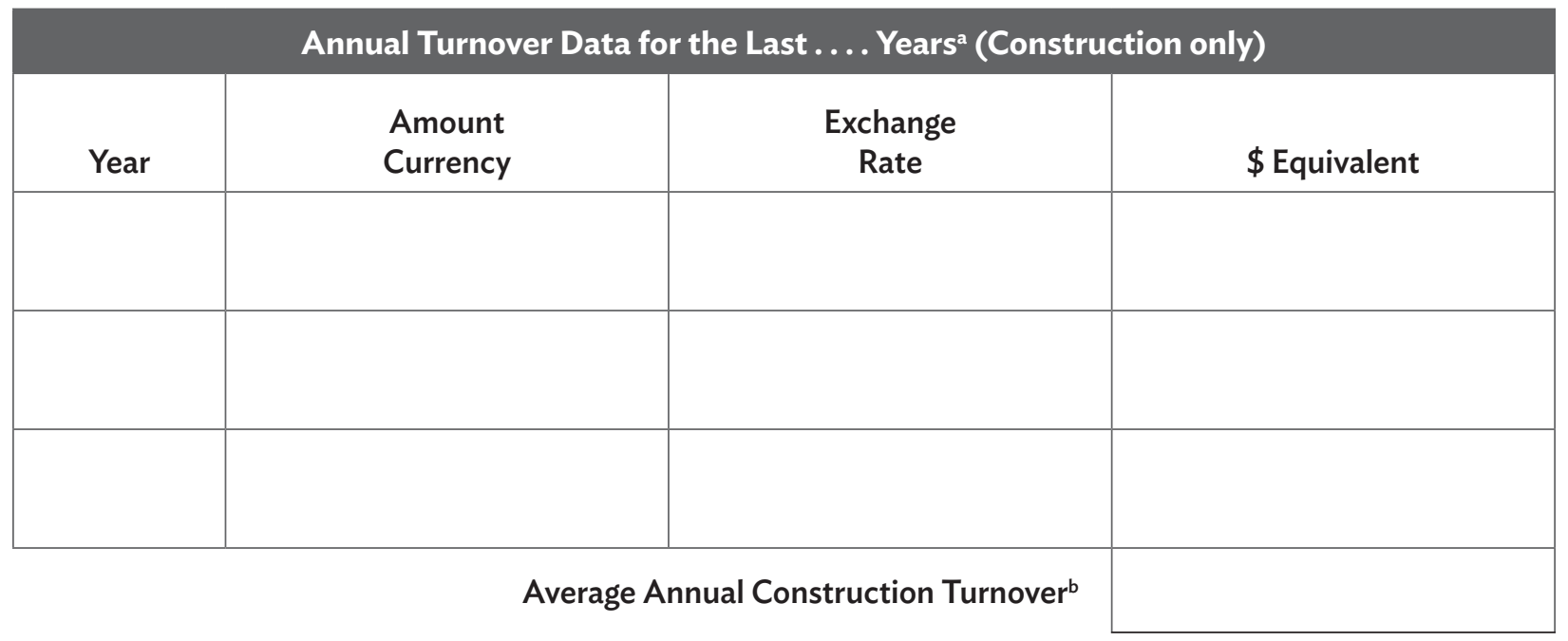

a The Employer should insert the period described in Criterion 2.3.2 of Section 3 (Evaluation and Qualification Criteria).

b To determine the average annual construction turnover, the Employer shall divide the sum of each year's annual turnover by the number of years, for which such information was requested. 


\section{Form FIN - 3: Availability of Financial Resources}

Bidders must demonstrate sufficient financial resources, usually comprising of Working Capital supplemented by credit line statements or overdraft facilities and others to meet the Bidder's financial requirements for

(a) its current contract commitments, and

(b) the subject contract.

In case of a Joint Venture, each Joint Venture Partner must fill out this form separately and provide the Joint Venture Partner's name:

Joint Venture Partner:

\begin{tabular}{|c|c|c|}
\hline \multicolumn{3}{|c|}{ Financial Resources } \\
\hline No. & Source of financing & Amount ( $\$$ equivalent) \\
\hline 1 & Working Capital (to be taken from FIN - 1) & \\
\hline 2 & Credit Line $^{\mathrm{a}}$ & \\
\hline 3 & Other Financial Resources & \\
\hline & Total Available Fi & \\
\hline
\end{tabular}

a To be substantiated by a letter from the bank issuing the line of credit. 


\section{Form FIN - 4: Financial Requirements for Current Contract Commitments}

Bidders (or each Joint Venture partner) should provide information on their current commitments on all contracts that have been awarded, or for which a letter of intent or acceptance has been received, or for contracts approaching completion, but for which an unqualified, full completion certificate has yet to be issued.

In case of a Joint Venture, each Joint Venture Partner must fill out this form separately and provide the Joint Venture Partner's name:

Joint Venture Partner:

\begin{tabular}{|c|c|c|c|c|c|c|}
\hline \multicolumn{9}{|c|}{ Current Contract Commitments } \\
\hline No. & $\begin{array}{c}\text { Name of } \\
\text { Contract }\end{array}$ & $\begin{array}{c}\text { Employer's } \\
\text { Contact } \\
\text { (Address, } \\
\text { Tel, Fax) }\end{array}$ & $\begin{array}{c}\text { Contract } \\
\text { Completion } \\
\text { Date }\end{array}$ & $\begin{array}{c}\text { Outstanding } \\
\text { Contract } \\
\text { Value } \\
(\mathrm{X})^{\mathrm{a}}\end{array}$ & $\begin{array}{c}\text { Remaining } \\
\text { Contract } \\
\text { Period in } \\
\text { months (Y) }\end{array}$ & $\begin{array}{c}\text { Monthly Financial } \\
\text { Resources } \\
\text { Requirement } \\
\text { (X/Y) }\end{array}$ \\
\hline 1 & & & & & & \\
\hline 2 & & & & & & \\
\hline 3 & & & & & & \\
\hline 4
\end{tabular}

a Remaining outstanding contract values to be calculated from 28 days prior to the bid submission deadline (\$ equivalent based on the foreign exchange rate as of the same date).

b Remaining contract period to be calculated from 28 days prior to bid submission deadline. 


\section{Form FIN - 5: Self-Assessment Tool for Bidder's Compliance to Financial Resources (Criterion 2.3.3 of Section 3)}

This form requires the same information submitted in Forms FIN - 3 and FIN - 4. All conditions of "Available Financial Resources Net of CCC $\geq$ Requirement for the Subject Contract" must be satisfied to qualify.

\section{Form FIN - 5A: For Single Entities}

\begin{tabular}{|c|c|c|c|c|c|}
\hline $\begin{array}{l}\text { For Single Entities: } \\
\text { (A) }\end{array}$ & $\begin{array}{l}\text { Total Available } \\
\text { Financial } \\
\text { Resources from } \\
\text { FIN - } 3 \\
\text { (B) }\end{array}$ & $\begin{array}{l}\text { Total Monthly } \\
\text { Financial Requirement } \\
\text { for Current Contract } \\
\text { Commitments (CCC) } \\
\text { from FIN - } 4 \\
\text { (C) }\end{array}$ & $\begin{array}{c}\text { Available } \\
\text { Financial } \\
\text { Resources Net } \\
\text { of CCC } \\
D=(B-C)\end{array}$ & $\begin{array}{l}\text { Requirement } \\
\text { for the Subject } \\
\text { Contract } \\
\text { (E) }\end{array}$ & $\begin{array}{l}\text { Results: } \\
\text { Yes or No } \\
\text { [D must be } \\
\text { greater than or } \\
\text { equal to } E \text { ] } \\
\text { (F) }\end{array}$ \\
\hline$\overline{(\text { Name of Bidder) }}$ & & & & & \\
\hline
\end{tabular}

\section{Form FIN - 5B: For Joint Ventures}

\begin{tabular}{|c|c|c|c|c|c|}
\hline $\begin{array}{l}\text { For Joint } \\
\text { Ventures: } \\
\text { (A) }\end{array}$ & $\begin{array}{l}\text { Total Available } \\
\text { Financial } \\
\text { Resources from } \\
\text { FIN - } 3 \\
\text { (B) }\end{array}$ & $\begin{array}{l}\text { Total Monthly } \\
\text { Financial Requirement } \\
\text { for Current Contract } \\
\text { Commitments (CCC) } \\
\text { from FIN - } 4 \\
\text { (C) }\end{array}$ & $\begin{array}{c}\text { Available } \\
\text { Financial } \\
\text { Resources Net } \\
\text { of CCC } \\
D=(B-C)\end{array}$ & $\begin{array}{l}\text { Requirement } \\
\text { for the Subject } \\
\text { Contract } \\
\text { (E) }\end{array}$ & $\begin{array}{l}\text { Results: } \\
\text { Yes or No } \\
\text { [D must be } \\
\text { greater than or } \\
\text { equal to } E \text { ] } \\
\text { (F) }\end{array}$ \\
\hline One Partner: & & & & & \\
\hline (Name of Partner) & & & & ……................ & \\
\hline Each Partner: & & & & & \\
\hline$(\overline{\text { Name of Partner } 1)}$ & & & & …….......... & \\
\hline$(\overline{\text { Name of Partner } 2)}$ & & & & ……........... & \\
\hline (Name of Partner 3$)$ & & & & ……........... & \\
\hline $\begin{array}{l}\text { All partners } \\
\text { combined }\end{array}$ & \multicolumn{2}{|c|}{$\begin{array}{l}\sum D=\text { Sum of available financial resources } \\
\text { net of current contract commitments for all } \\
\text { partners }\end{array}$} & $\sum D=-------$ & $\ldots \ldots \ldots . . . .^{a}$ & \\
\hline
\end{tabular}

a The Employer should insert here the total requirement for the Subject Contract (for both, single entity and all partners combined) as defined in Criterion 2.3.3 of Section 3.

b The Employer should insert here the required share for one partner as defined in Criterion 2.3.3 of Section 3.

c The Employer should insert here the required share for each partner as defined in Criterion 2.3.3 of Section 3.

\section{NOTE}

Form FIN - 5 is made available for use by the Bidder as a self-assessment tool, and by the Employer as an evaluation work sheet, to determine compliance with the financial resources requirement as stated in 2.3.3. Failure to submit Form FIN - 5 by the Bidder shall not lead to bid rejection. 


\section{Form EXP - 1: Contracts of Similar Size and Nature}

Fill out one (1) form per contract. Each contract shall be supported by documents such as Signed Contract Agreement or Certificate of Completion of the Works.

The exchange rate to be used to calculate the value of the contract for conversion to a specific currency shall be the selling rate of the Borrower's Central bank on the date of the contract.

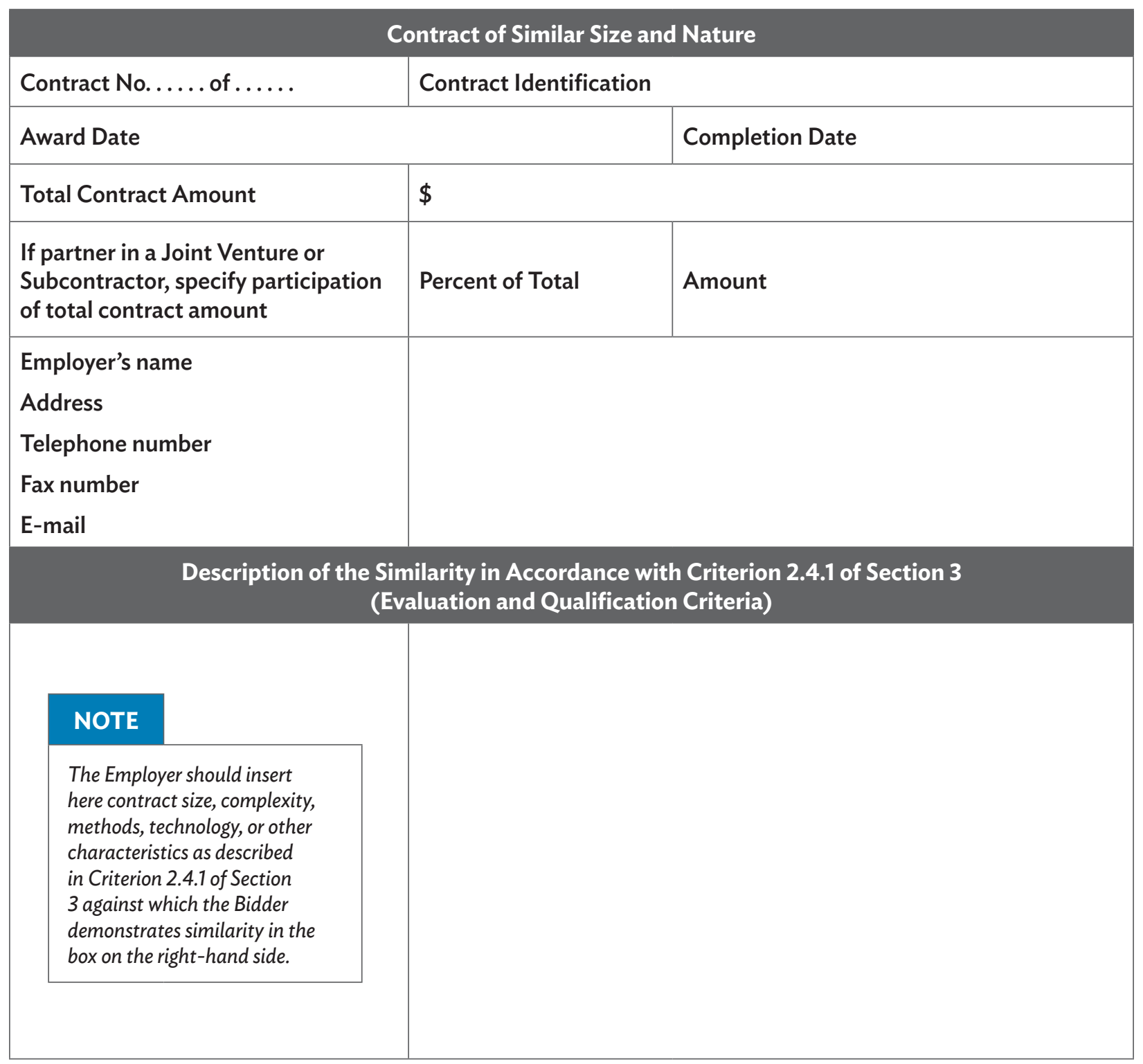




\section{Form EXP - 2: Construction Experience in Key Activities}

Fill out one (1) form per contract. Each contract shall be supported by documents such as Signed Contract Agreement or Certificate of Completion of the Works .

Each Bidder must fill out this form.

If complied by Specialist Subcontractors, each Specialist Subcontractor must fill out this form and provide the Specialist Subcontractor's name:

Specialist Subcontractor:

\section{Contract with Similar Key Activities}

\begin{tabular}{l|l} 
Contract No...... of ....... & Contract Identification
\end{tabular}

\begin{tabular}{|l|l|l|}
\hline Award Date & Completion Date \\
\hline Total Contract Amount & $\$$ & Amount \\
\hline $\begin{array}{l}\text { If partner in a Joint Venture or } \\
\text { Subcontractor, specify participation } \\
\text { of total contract amount }\end{array}$ & Percent of Total & Amer name \\
\hline $\begin{array}{l}\text { Employer's } \\
\text { Address }\end{array}$ & \\
Telephone number & \\
Fax number & & \\
E-mail &
\end{tabular}

\section{NOTE}

The Employer should insert here the highly specialized construction activities listed under Criterion 2.4.2 of Section 3 against which the Bidder demonstrates similarity in the box on the right-hand side. 


\section{Form EXP - 3: Specific Experience in Managing Environmental, Health and Safety Aspects}

Fill out one form per contract.

Each Bidder must fill out this form.

In case of a Joint Venture, each Joint Venture Partner must fill out this form separately and provide the Joint Venture Partner's name:

Joint Venture Partner:

1. Key Requirement no 1 in accordance with Criterion 2.4.3 of Section 3:

\begin{tabular}{|l|l|l|l|l|}
\hline Contract Identification & \multicolumn{3}{|l|}{} \\
\hline Award date & \multicolumn{3}{|l|}{} \\
\hline Completion date & $\begin{array}{c}\text { Prime } \\
\text { Contractor } \\
\square\end{array}$ & $\begin{array}{c}\text { Member } \\
\text { in JV } \\
\square\end{array}$ & $\begin{array}{c}\text { Management } \\
\text { Contractor } \\
\square\end{array}$ & Subcontractor \\
\hline Role in Contract & & US\$ & \\
\hline Total Contract Amount & & & \\
\hline Details of relevant experience & & & \\
\hline
\end{tabular}

2. Key Requirement no 2 in accordance with Criterion 2.4.3 of Section 3:

3. Key Requirement no 3 in accordance with Criterion 2.4.3 of Section 3:

\section{Form EXP - 4: Environmental, Health and Safety Certification}

Please provide the following information:

Availability of the following valid ISO certification or internationally-recognized equivalent (equivalency to be demonstrated by the Bidder), and applicable to the worksite:

[Select the required certifications from below] ${ }^{\mathrm{a}}$

- Quality management certificate ISO 9001

- Environmental management certificate ISO 14001

- Health and Safety management certificate ISO 45001

Depending on the environmental, health and safety issues of the worksite and the type of competition planned (national or international), the list of required certifications may be restricted to those corresponding to the main issue of the worksite management, or removed altogether. 


\section{Form EXP - 5: Environmental, Health and Safety Documentation}

Please provide the following information:

Availability of in-house policies and procedures acceptable to the Employer for EHS management:

1. Existence of an Ethics Charter.

2. Existence of a system for monitoring compliance with EHS commitments for the Bidder's Subcontractors and all its partners.

3. Existence of official company procedures for the management of the following relevant points:

[Select 3-5 that apply for the worksite from below options-as per Section 2]

- EHS resources and facilities and EHS monitoring system;

- Project Areas management information (base camps, quarries, burrow pits, storage areas);

- Health and Safety on worksites policy and related guidance;

- Local recruitment and EHS trainings of local staff/subcontractors/local partners;

- Community stakeholder engagement practice;

- Traffic management practice;

- Hazardous products management practice;

- Waste management practice;

- Protection of water resources;

- Biodiversity protection practices;

- Site rehabilitation and revegetation practice;

- Local cultural heritage protection practice;

- Erosion and sedimentation practices;

- Control of infectious and communicable diseases (HIV/AIDS, malaria, COVID-19 etc)

\section{Form EXP - 6: Environmental, Health and Safety Dedicated Personnel}

Please provide CV [Form PER-2] of the in-house personnel of the main contractor/Joint Venture partners for the EHS positions specified in Section 6 (Employers Requirements):

[For example]

- Environmental Specialist

- Health and Safety Specialist 


\section{Section 5: Eligible Countries}

This section contains the list of eligible countries. Please choose one of the following cases and follow the instructions as appropriate.

\section{NOTES}

For Contracts to be financed by loans/grants from

1. OCR without cofinancing resources:

Unless a waiver of ADB member procurement eligibility restrictions was approved by the ADB Board of Directors, please insert the most recent list of $A D B$ members obtainable from www.adb.org/about/members

EXCEPTION: If any other contract under the project is financed by cofinancing resources that are administered by ADB (other than those listed in paragraph 2 below), then please state "No nationality restrictions apply, other than any restrictions arising from ITB 4.8."

2. Regular loan from OCR with cofinancing resources from any one of the following funds:

(i) Asian Clean Energy Fund,

(ii) Japan Fund for Poverty Reduction,

(iii) Investment Climate Facilitation Fund,

(iv) Japan Fund for the Joint Credit Mechanism, and

(v) e-Asia and Knowledge Partnership Fund,

Unless a waiver of $A D B$ member procurement eligibility restrictions was approved by the ADB Board of Directors, please insert the most recent list of $A D B$ members obtainable from www.adb.org/about/members

3. Concessional loan from OCR with cofinancing resources from any one of the following funds:

(i) Asian Clean Energy Fund,

(ii) Japan Fund for Poverty Reduction,

(iii) Japan Fund for Public Policy Training,

(iv) Japan Fund for Information and Communication Technology,

(v) Investment Climate Facilitation Fund, and

(vi) e-Asia and Knowledge Partnership Fund,

Unless a waiver of ADB member procurement eligibility restrictions was approved by the ADB Board of Directors, please insert the most recent list of $A D B$ members obtainable from www.adb.org/about/members

4. Regular loan from $O C R$ with cofinancing resources other than those listed in paragraph 2 above: Please state "No nationality restrictions apply, other than any restrictions arising from ITB 4.8."

5. Concessional loan from OCR with cofinancing resources other than those listed in paragraph 3 above:

Please state "No nationality restrictions apply, other than any restrictions arising from ITB 4.8."

6. ADF without cofinancing resources:

Unless a waiver of $A D B$ member procurement eligibility restrictions was approved by the ADB Board of Directors, please insert the most recent list of $A D B$ members that have contributed to $A D F$ resources, and all $A D B$ developing member countries.

EXCEPTION: If any other contract under the project is financed by cofinancing resources that are administered by ADB (other than those listed in paragraph 7 below), then please state "No nationality restrictions apply, other than any restrictions arising from ITB 4.8." 
7. ADF with cofinancing resources from any one of the following funds:

(i) Asian Clean Energy Fund,

(ii) Japan Fund for Poverty Reduction,

(iii) Japan Fund for Public Policy Training,

(iv) Japan Fund for Information and Communication Technology,

(v) Investment Climate Facilitation Fund, and

(vi) e-Asia and Knowledge Partnership Fund,

Unless a waiver of ADB member procurement eligibility restrictions was approved by the ADB Board of Directors, please insert the most recent list of $A D B$ members that have contributed to ADF resources, and all ADB developing member countries.

8. ADF with cofinancing resources other than those listed in paragraph 7 above:

Please state "No nationality restrictions apply, other than any restrictions arising from ITB 4.8." 


\section{Section 6: Employer's Requirements}

This section contains the Specifications, Drawings, Supplementary Information that describe the Works to be procured, Personnel Requirements, and Equipment Requirements.

\section{Table of Contents}

Specifications

Environmental, Health and Safety Management Requirement.

Drawings.

Supplementary Information Regarding Works to Be Procured ........................................................................ 116

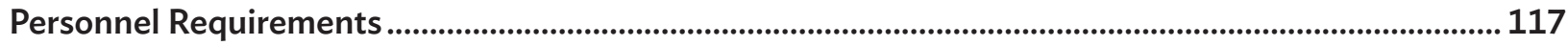

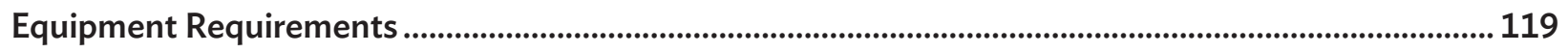




\section{Specifications}

\section{NOTES}

1. Precise and clear specifications are a prerequisite for Bidders to respond realistically and competitively to the requirements of the Employer without qualifying or conditioning their bids. In the context of open competitive bidding, the specifications must be drafted to permit the widest possible competition and, at the same time, present a clear statement of the required standards of materials, plant, other supplies, and workmanship to be provided. Only if this is done will the objectives of economy, efficiency, and equality in procurement be realized, responsiveness of bids be ensured, and the subsequent task of bid evaluation facilitated. The specifications should require that all materials, plant, and other supplies to be incorporated in the works are new, unused, of the most recent or current models, and incorporate all recent improvements in design and materials unless provided otherwise in the contract. A clause setting out the scope of the works is often included at the beginning of the specifications, and it is customary to give a list of the drawings. Where the contractor is responsible for the design of any part of the permanent works, the extent of his obligations must be stated. (Ref. GCC Subclause 23.1 Designs by Contractor and Approval by the Project Manager)

2. Samples of specifications from previous similar projects in the same country are useful in this respect. ADB encourages the use of metric units. Most specifications are normally written specially by the Employer or project manager to suit the contracts for the works in hand. There are no standard specifications for universal application in all sectors in all countries, but there are established principles and practices that are reflected in these documents.

3. There are considerable advantages in standardizing general specifications for repetitive works in recognized public sectors, such as highways, ports, railways, urban housing, irrigation, and water supply, in the same country or region where similar conditions prevail. The general specifications should cover all classes of workmanship, materials, and equipment commonly involved in construction, although not necessarily to be used in a particular works contract. Deletions or addenda should then adapt the general specifications to the particular works.

4. Care must be taken in drafting specifications to ensure that they are not restrictive. In the specification of standards for materials, plant, other supplies, and workmanship, recognized international standards should be used as much as possible. Where other particular standards are used, whether national standards of the Borrower's country or other standards, the specifications should state those materials, plant, other supplies, and workmanship meeting other authoritative standards, and which ensure substantially equal performance, as the standards mentioned, will also be acceptable.

5. Employers should decide whether alternative technical solutions to specified parts of the works are to be permitted. Alternatives are appropriate in cases where obvious (and potentially less costly) alternative solutions are possible to the technical solutions indicated in the bidding documents for certain elements of the Works, taking into consideration the comparative specialized advantage of potential Bidders. For example:

- $\quad$ pile foundations (proprietary methods and different material);

- bridge foundations (open well, caissons, piles, etc.);

- columns, beams, decking (reinforced concrete, prestressed concrete, steel, etc.);

- proprietary methods for post-tensioning concrete;

- lining of canals;

- $\quad$ pipeline materials, coating, jointing;

- $\quad$ road surfacing (asphalt, concrete, etc.);

- transmission tower design and erection;

- $\quad$ street lighting;

- offshore foundations; and

- offshore trestle spans

6. The Employer should provide a description of the selected parts of the Works with appropriate references to drawings, specifications, bill of quantities, and design or performance criteria, stating that the alternative solutions shall be at least structurally and functionally equivalent to the basic design parameters and specifications.

7. Such alternative solutions shall be accompanied by all information necessary for a complete evaluation by the Employer, including drawings, design calculations, technical specifications, breakdown of prices, proposed construction methodology, and other relevant details. 


\section{Environmental, Health and Safety Management Requirement}

\section{NOTES}

1. The Employer's team preparing the EHS requirements should include a suitably qualified Environmental, Health and Safety specialist/s as determined by the EMP. The Employer should attach or refer to the Employer's environmental, health and safety policies that will apply to the project if available.

2. Based on the EIA undertaken for the project and this specific contract, the Employer shall provide key EHS risks and impacts and expectations on contractors to manage the risks and impacts. This may include as appropriate, but not limited to a summary of: key expectations in managing labor and working conditions, protection of the environment, health and safety and security of the site, community health and safety, management of safety of hazardous materials, resource efficiency and pollution prevention and management, biodiversity conservation and sustainable management of living natural resources etc. Any summary (key) information provided here shall not be inconsistent with the more detailed requirements in the bidding document

3. The Employer should highlight the requirement of a Site Specific Environmental/Health and Safety Management Plan (SSEMP/SSHSMP) to be prepared based on the outline Environmental Health and Safety Management Plan (EHSMP) submitted as part of the Contractor's technical proposal. The SSEMP/SSHSMP shall be submitted within the contractual timeline (e.g. 28 days) outlined in the Contract Conditions. The Engineer/Project Manager shall endeavor to issue no-objection of the SSEMP/SSHSMP within a prescribed period (e.g.10 days) upon receipt of the SSEMP/SSHSMP, if the EHS requirements for the plan is met. No physical works shall commence on site prior to the confirmation of no objection of the SSEMP/SSHSMP has been obtained from the Engineer as per Contract Conditions.

\section{Minimum Content of Requirements}

4. In preparing detailed specifications for requirements, the specialists should refer to and consider:

- $\quad$ project reports e.g. EIA/EMP

- consent/permit conditions

- required standards including ADB Safeguard Policy Statement and related EHS Guidelines

- relevant international conventions or treaties etc., national legal and/or regulatory requirements and standards (where these represent higher standards than the ADB Guidelines)

- relevant international standards e.g. WHO Guidelines for Safe Use of Pesticides

- relevant sector standards e.g. EU Council Directive 91/271/EEC Concerning Urban Waste Water Treatment

- grievance redress mechanism including types of grievances to be recorded and how to protect confidentiality

5. The detail specification for EHS should, to the extent possible, describe the intended outcome rather than the method of working.

6. The EHS requirements should be prepared in manner that does not conflict with the relevant General Conditions of Contract (and the corresponding Particular Conditions if any) and other parts of the specifications.

\section{Payment for EHS Requirements}

7. The Employer's environmental, health and safety, and procurement specialists should consider how the Contractor will cost the delivery of these requirements. In the majority of cases, the payment for the delivery of these requirements shall be a subsidiary obligation of the Contractor covered under the prices quoted for other Bill of Quantity items. For example, normally the cost of implementing work place safe systems of work, including the measures necessary for ensuring traffic and road safety, shall be covered by the Bidder's rates for the relevant works. Alternatively, provisional sums could be set aside for discrete activities for example to encourage the contractor to deliver additional environmental, health and safety outcomes beyond the requirement of the Contract. 


\section{Drawings}

\section{NOTES}

1. It is customary to bind the drawings in a separate volume, which is often larger than other volumes of the contract documents. The size will be dictated by the scale of the drawings, which must not be reduced to the extent that details are rendered illegible.

2. A simplified map showing the location of the Site in relation to the local geography, including major roads, ports, airports, and railroads, is helpful.

3. The construction drawings, even if not fully developed, must show sufficient details to enable Bidders to understand the type and complexity of the work involved and to price the bill of quantities or activity schedule. 


\section{Supplementary Information Regarding Works to Be Procured}

\section{NOTES}

The Employer is required to include local regulations and guidance specific to COVID-19 prevention and controls, and worksite safety measures requirements that are deemed applicable to the contract, as well as the applicable international good practices on Health and Safety for the contract as Supplementary Information under Section 6 - Employer's Requirements.

The Employer should attach the Environmental Impact Assessment ("EIA") and the Environmental Management Plan ("EMP") as Supplementary Information in the Employer's Requirements. 


\section{Personnel Requirements}

Using Form PER - 1 and PER - 2 in Section 4 (Bidding Forms), the Bidder must demonstrate that it has personnel who meet the following requirements:

\begin{tabular}{|c|c|c|c|}
\hline No. & Position & $\begin{array}{c}\text { Total Work } \\
\text { Experience } \\
\text { [years] }\end{array}$ & $\begin{array}{c}\text { Experience in } \\
\text { Similar Work } \\
\text { [years] }\end{array}$ \\
\hline 1 & & & \\
\hline 2 & & & \\
\hline 3 & & & \\
\hline 4 & & & \\
\hline 5 & & & \\
\hline & & & \\
\hline
\end{tabular}

\section{NOTES}

The managerial and technical competence of a contractor is largely related to key personnel on site. The extent to which the Bidder should demonstrate having staff with extensive experience should be limited to those requiring critical operational or technical skills. The personnel requirement should therefore refer to a limited number of such key personnel, for instance, the project or contract manager and those superintendents working under the project manager who will be responsible for major components (e.g., superintendents specialized in dredging, piling, tunneling, or earthworks, as required for each particular project). Requirements should specify

(a) the minimum number of years of experience in similar position; and

(b) the minimum number of years of experience and/or number of comparable projects carried out in a specified number of preceding years.

The requirement of education and academic qualifications is normally unnecessary for such positions, as contractors often employ competent staff who have learned their profession "on the job" rather than through academic training. It is appropriate to specify that certain positions are filled by individuals who have held posts of comparable authority for, say, 3 years with the Bidder, so that key staff in executive site positions have sufficient knowledge of the Bidder's management, policy, procedures, and practices to act with confidence and authority within that framework. 
Using Form EXP-6 in Section 4 (Bidding Forms), the Bidder must demonstrate that it has EHS personnel who meet the following requirements:

[Note: Insert in the following table, the minimum key EHS specialists required to execute the contract, taking into account the nature, scope, complexity and risks of the contract.]

\section{Key Personnel as determined by the EMP and other safeguard management plans}

\begin{tabular}{c|l|l|l|l|}
$\begin{array}{c}\text { Item } \\
\text { No. }\end{array}$ & \multicolumn{1}{|c|}{ Position/specialization } & $\begin{array}{c}\text { Relevant academic } \\
\text { qualifications }\end{array}$ & $\begin{array}{c}\text { Minimum years of } \\
\text { relevant work experience }\end{array}$ & $\begin{array}{c}\text { Minimum time } \\
\text { on-site (\%FTE) }\end{array}$ \\
\hline 1 & [Environmental Specialist $]$ & $\begin{array}{l}\text { [e.g. degree in relevant } \\
\text { environmental subject }]\end{array}$ & $\begin{array}{l}\text { [e.g. [years] working on } \\
\text { road contracts in similar } \\
\text { work environments] }\end{array}$ & \\
\hline 2 & [Health and Safety Specialist] & \multicolumn{3}{|l}{} \\
\hline
\end{tabular}

1 The sum of the two coefficients $A c$ and $B c$ should be 1 (one) in the formula for each currency. Normally, both coefficients shall be the same in the formulas for all currencies, since coefficient $A$, for the nonadjustable portion of the payments, is a very approximate figure (usually $0.10 \sim 0.20$ ) to take account of fixed cost elements or other nonadjustable components. The sum of the adjustments for each currency is added to the Contract Price. 


\section{Equipment Requirements}

Using Form EQU in Section 4 (Bidding Forms), the Bidder must demonstrate that it has the key equipment listed below:

\begin{tabular}{|c|c|c|}
\hline No. & Equipment Type and Characteristics & Minimum Number Required \\
\hline 1 & & \\
\hline 2 & & \\
\hline 3 & & \\
\hline 4 & & \\
\hline 5 & & \\
\hline & & \\
\hline
\end{tabular}

\section{NOTES}

The Employer should only specify bulky or specialized items that are critical for the type of project to be implemented, and which may be difficult for the contractor to obtain quickly. Examples may include items such as heavy lift cranes and piling barges, dredgers, tunnel boring machines, or asphalt mixing plant.

An inventory of construction equipment represents a high capital cost overhead to a contractor. Consequently, not all competent potential Bidders will maintain an inventory of high-value items that are in suitable condition for major contracts. This is particularly so with management contractors, who undertake construction projects mainly by subcontracting. In most cases, Bidders can readily purchase, lease, or hire equipment; examples may include items such as heavy lift cranes and piling barges, etc. Even in such cases, contractors may not own the specialized items of equipment, and may rely on Specialist Subcontractors or equipment-hire firms. The availability of such Subcontractors and of the specified equipment should be subject to verification prior to contract award. The terms of any lease or hire agreement for equipment should preferably include a provision that the equipment will remain on the site (or be vested in the Employer) in the event of default of the contractor, thereby ensuring more timely continuity of work by a replacement contractor. 


\section{Section 7: General Conditions of Contract}

The General Conditions of Contract (GCC), read in conjunction with the Particular Conditions of Contract (PCC) and other documents listed therein should be a complete document expressing fairly the rights and obligations of both parties. The standard text of the GCC must be retained intact to facilitate its reading and interpretation by Bidders and its review by ADB. Any amendments and additions to the GCC, specific to the contract in hand, should be introduced in Section 8 (Particular Conditions of Contract).

The use of standard conditions of contract for all building and civil works throughout a country will ensure comprehensiveness of coverage, general acceptability of its provisions, savings in cost and time in bid preparation and review, and the development of a solid background of legal case histories.

The form of Conditions of Contract that follows has been developed on the basis of considerable international experience in the drafting and management of contracts, bearing in mind a trend in the construction industry toward simpler, more straightforward language.

The GCC in this bidding document provides for the usual arrangement where the Contractor constructs the Works in accordance with design provided by the Employer, and also for contracts that include, or wholly comprise, contractor-designed civil, mechanical or electrical works. Section 7 is generally based on the Conditions of Contract of the World Bank's Standard Bidding Documents for Procurement of Works, Smaller Contracts, December 2012.

The GCC can be used for lump sum contracts and, with the modifications recommended in the PCC, also for small unit price contracts. Design work by the contractor is also provided for in these Conditions.

For relatively simple contracts, the Short Form of Contract, First Edition, 1999 prepared by the Fédération Internationale des Ingénieurs-Conseils (FIDIC) is recommended to be used. 


\section{Table of Clauses}

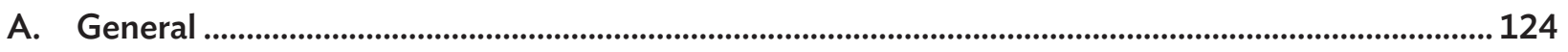

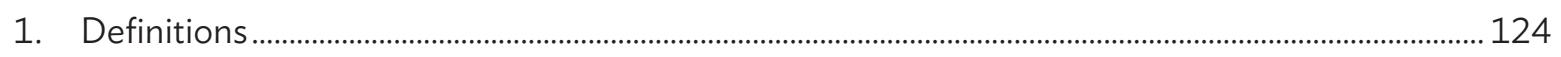

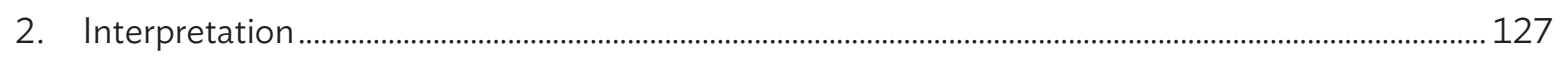

3. Language and Law.............................................................................................................................. 127

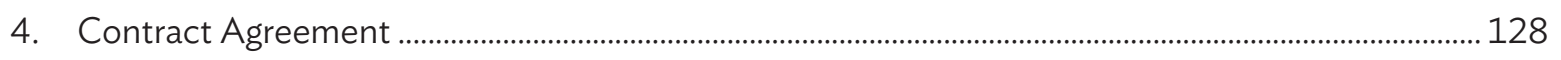

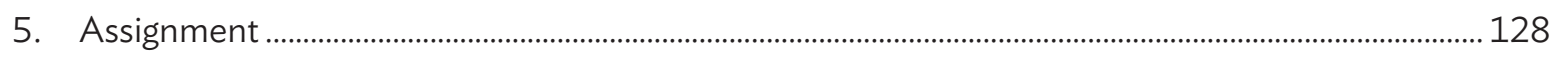

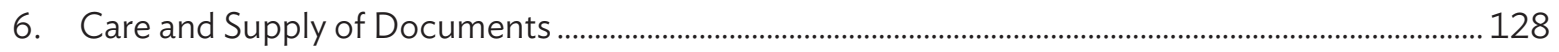

7. Confidential Details ............................................................................................................................................ 128

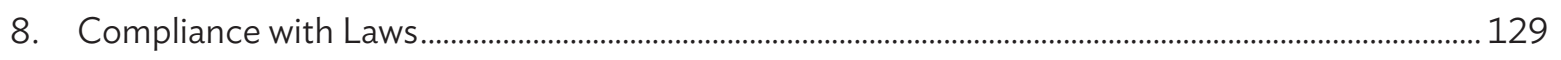

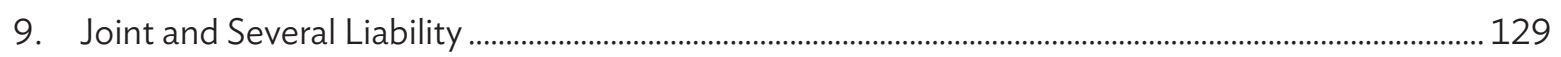

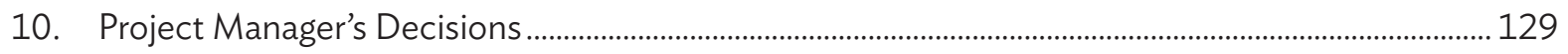

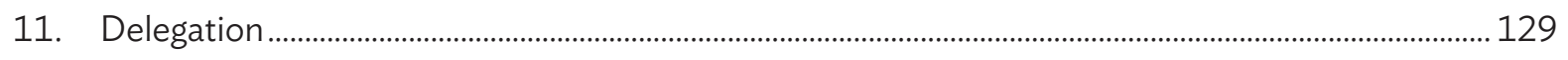

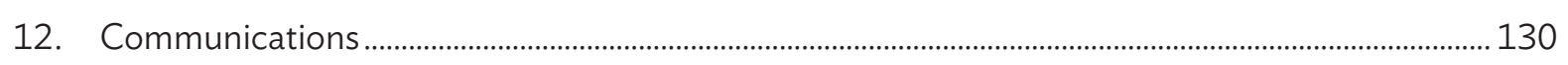

13. Subcontracting .............................................................................................................................................. 130

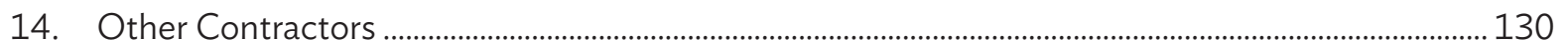

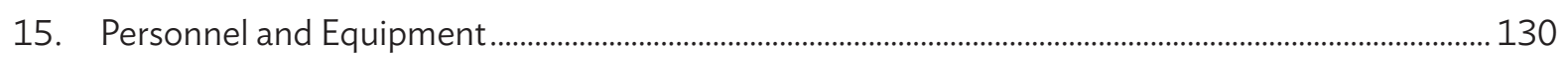

16. Employer's and Contractor's Risks .......................................................................................................... 130

17. Employer's Risks...................................................................................................................................... 131

18. Contractor's Risks............................................................................................................................................ 131

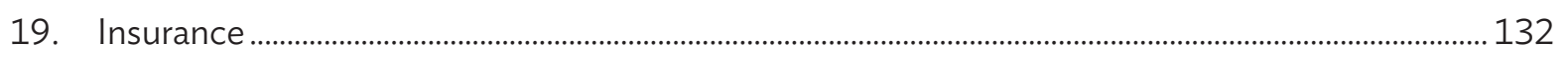

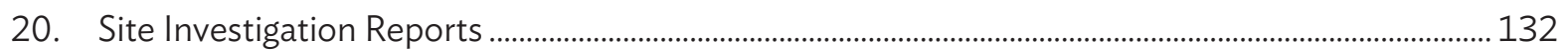

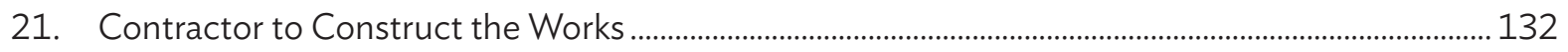

22. The Works to Be Completed by the Intended Completion Date ........................................................ 132

23. Designs by Contractor and Approval by the Project Manager................................................................... 133

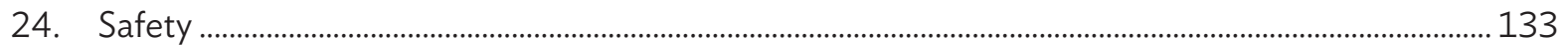

25. Discoveries.......................................................................................................................................... 133

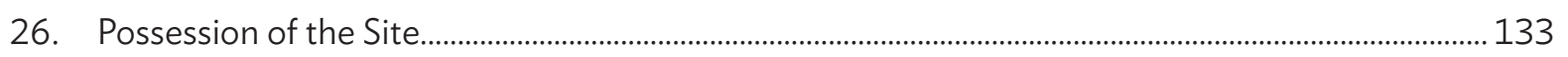

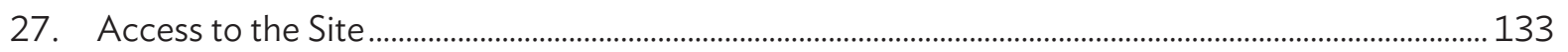

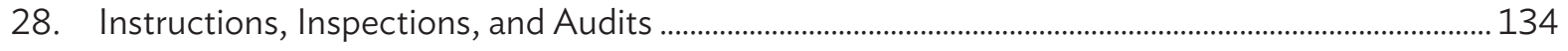

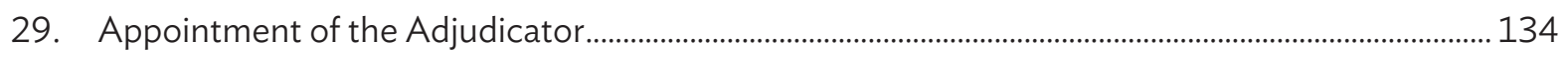

30. Procedure for Disputes .......................................................................................................................... 135

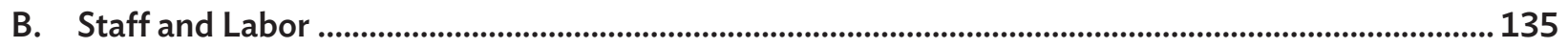

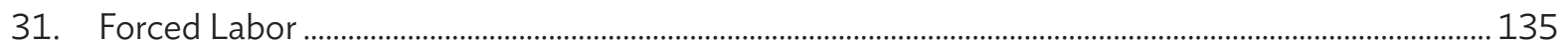

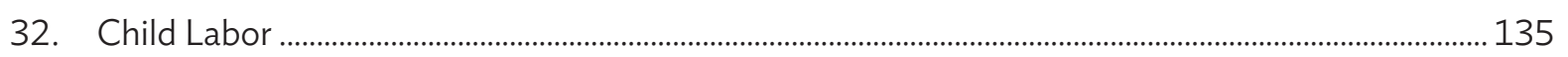

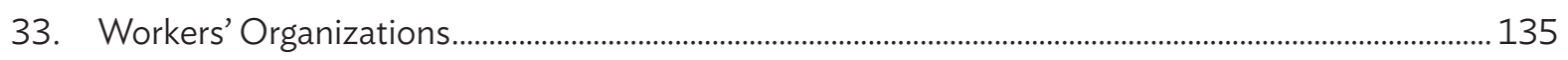

34. Nondiscrimination and Equal Opportunity ........................................................................................ 136 


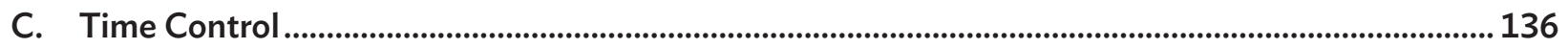

35. Program .............................................................................................................................................136

36. Extension of the Intended Completion Date .........................................................................................137

37. Acceleration .......................................................................................................................................137

38. Delays Ordered by the Project Manager ..................................................................................................137

39. Management Meetings ............................................................................................................................. 137

40. Early Warning ................................................................................................................................................. 137

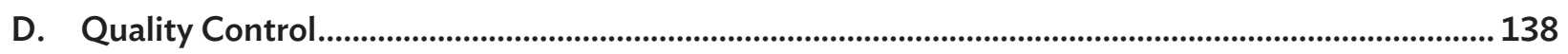

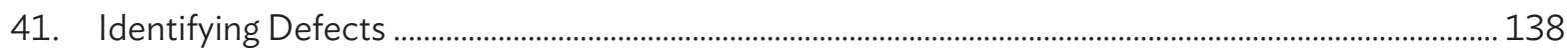

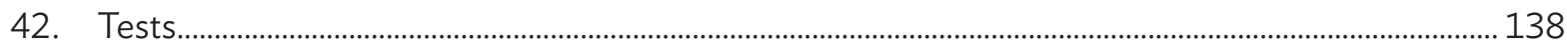

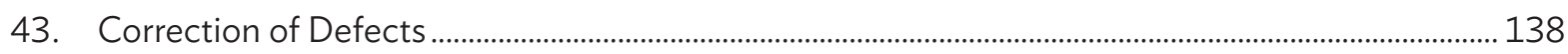

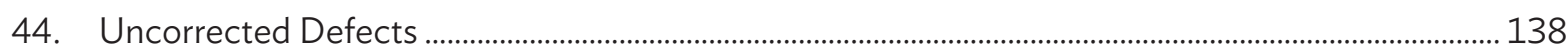

E. Cost Control ...................................................................................................................................... 138

45. Contract Price ........................................................................................................................................... 138

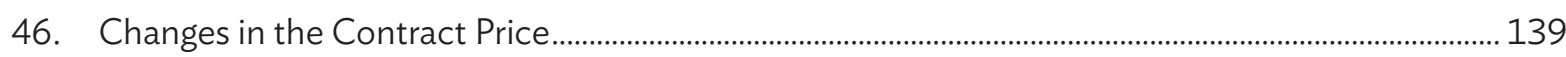

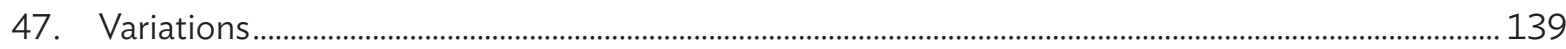

48. Cash Flow Forecasts .................................................................................................................................. 140

49. Payment Certificates ................................................................................................................................ 140

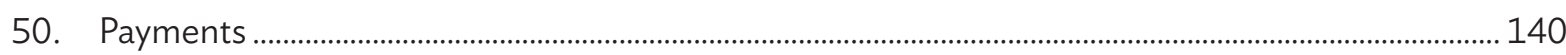

51. Compensation Events................................................................................................................................ 141

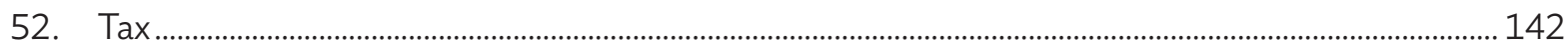

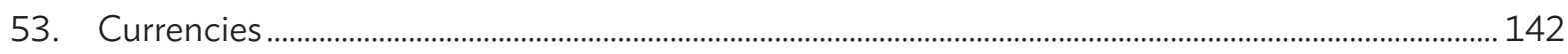

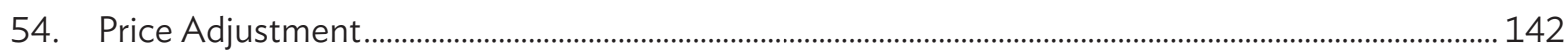

55. Retention ..................................................................................................................................... 143

56. Liquidated Damages ............................................................................................................................... 143

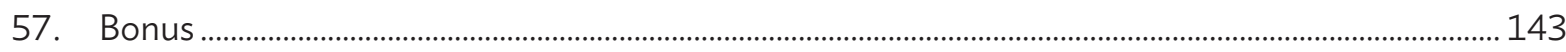

58. Advance Payment ............................................................................................................................... 143

59. Securities ................................................................................................................................. 144

60. Dayworks ............................................................................................................................................. 144

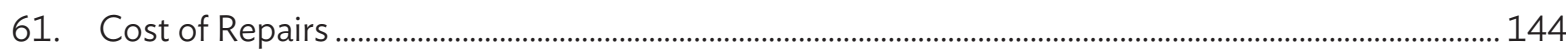

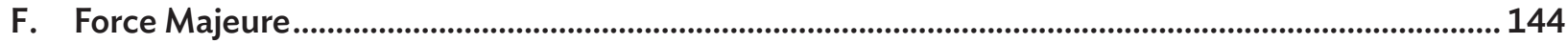

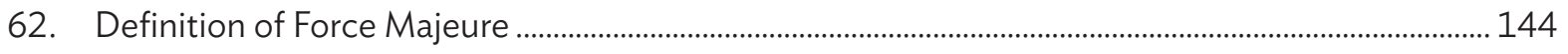

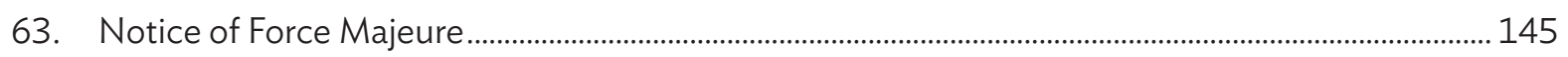

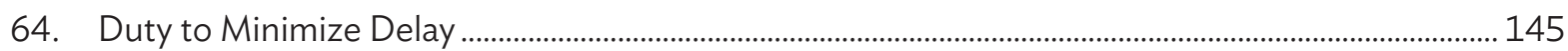

65. Consequences of Force Majeure...............................................................................................................146

66. Force Majeure Affecting Subcontractor .....................................................................................................146

67. Optional Termination, Payment, and Release ........................................................................................ 146

68. Release from Performance............................................................................................................................147 


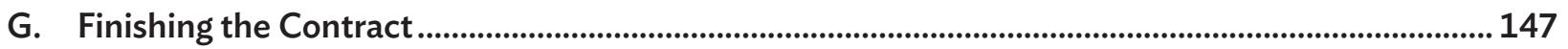

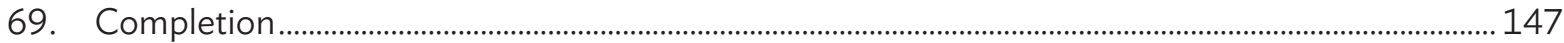

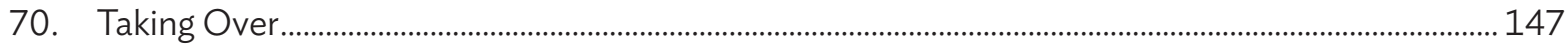

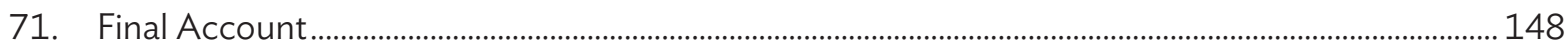

72. Operating and Maintenance Manuals............................................................................................................ 148

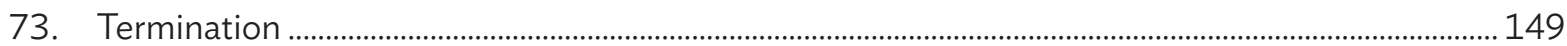

74. Fraud and Corruption ................................................................................................................................... 150

75. Payment upon Termination ................................................................................................................. 153

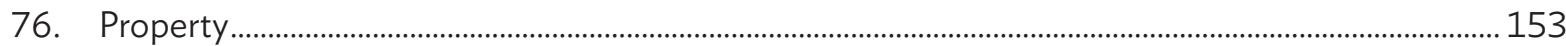

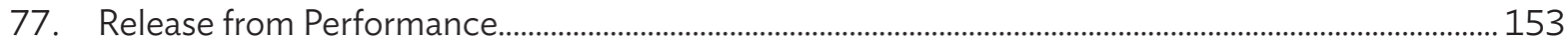

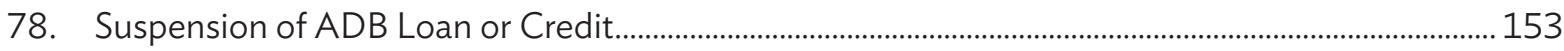

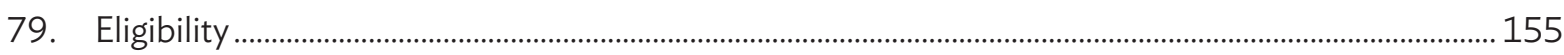


A. General

1. Definitions

1.1 Boldface type is used to identify defined terms.

(a) The Accepted Contract Amount means the amount accepted in the Letter of Acceptance for the execution and completion of the Works and the remedying of any defects.

(b) The Activity Schedule is a schedule of the activities comprising the construction, installation, testing, and commissioning of the Works in a lump sum contract. It includes a lump sum price for each activity, which is used for valuations and for assessing the effects of Variations and Compensation Events.

(c) The Adjudicator is the person appointed jointly by the Employer and the Contractor to resolve disputes in the first instance, as provided for in GCC 29.1 [Appointment of Adjudicator] hereunder.

(d) Bank means the financing institutions named in the Particular Conditions of Contract (PCC).

(e) Bill of Quantities means the priced and completed Bill of Quantities forming part of the Bid.

(f) Compensation Events are those defined in GCC 51.1 [Compensation Events] hereunder.

(g) The Completion Date is the date of completion of the Works as certified by the Project Manager, in accordance with GCC 69.1 [Completion].

(h) The Contract is the Contract between the Employer and the Contractor to execute, complete, and maintain the Works. It consists of the documents listed in GCC 2.3 below.

(i) The Contractor is the party whose Bid to carry out the Works has been accepted by the Employer.

(j) The Contractor's Bid is the completed bidding document submitted by the Contractor to the Employer.

(k) The Contract Price is the Accepted Contract Amount stated in the Letter of Acceptance and thereafter as adjusted in accordance with the Contract.

(I) Days are calendar days; months are calendar months. 
(m) Dayworks are varied work inputs subject to payment on a time basis for the Contractor's employees and Equipment, in addition to payments for associated Materials and Plant.

(n) A Defect is any part of the Works not completed in accordance with the Contract.

(o) The Defects Liability Certificate is the certificate issued by the Project Manager upon correction of defects by the Contractor.

(p) The Defects Liability Period is the period calculated from the Completion Date where the Contractor remains responsible for remedying defects.

(q) Drawings include calculations and other information provided or approved by the Project Manager for the execution of the Contract.

(r) The Employer is the party who employs the Contractor to carry out the Works, as specified in the PCC.

(s) Equipment is the Contractor's machinery and vehicles brought temporarily to the Site to construct the Works.

(t) Force Majeure means an exceptional event or circumstance: which is beyond a Party's control; which such Party could not reasonably have provided against before entering into the Contract; which, having arisen, such Party could not reasonably have avoided or overcome; and, which is not substantially attributable to the other Party.

(u) In writing or written means handwritten, typewritten, printed, or electronically made, and resulting in a permanent record.

(v) The Initial Contract Price is the Contract Price listed in the Employer's Letter of Acceptance.

(w) The Intended Completion Date is the date on which it is intended that the Contractor shall complete the Works. The Intended Completion Date is specified in the PCC. The Intended Completion Date may be revised only by the Project Manager by issuing an extension of time or an acceleration order.

(x) Letter of Acceptance means the formal acceptance by the Employer of the Bid and denotes the formation of the Contract at the date of acceptance. 
(y) Materials are all supplies, including consumables, used by the Contractor for incorporation in the Works.

(z) Party means the Employer or the Contractor, as the context requires.

(aa) PCC means Particular Conditions of Contract.

(bb) Plant is any integral part of the Works that shall have a mechanical, electrical, chemical, or biological function.

(cc) The Project Manager is the person named in the PCC (or any other competent person appointed by the Employer and notified to the Contractor, to act in replacement of the Project Manager) who is responsible for supervising the execution of the Works and administering the Contract.

(dd) Retention Money means the aggregate of all monies retained by the Employer pursuant to GCC 55.1 [Retention].

(ee) Schedules means the document(s) entitled schedules, completed by the Contractor and submitted with the Letter of Bid, as included in the Contract. Such document may include the Bill of Quantities, data, lists, and schedules of rates and/or prices.

(ff) The Site is the area defined as such in the PCC.

(gg) Site Investigation Reports are those that were included in the bidding documents and are factual and interpretative reports about the surface and subsurface conditions at the Site.

(hh) Specification means the Specification of the Works included in the Contract and any modification or addition made or approved by the Project Manager.

(ii) The Start Date is given in the PCC. It is the latest date when the Contractor shall commence execution of the Works. It does not necessarily coincide with any of the Site Possession Dates.

(ji) A Subcontractor is a person or corporate body who has a Contract with the Contractor to carry out a part of the work in the Contract, which includes work on the Site.

(kk) Temporary Works are works designed, constructed, installed, and removed by the Contractor that are needed for construction or installation of the Works.

(II) A Variation is an instruction given by the Project Manager, which varies the Works.

( $\mathrm{mm}$ ) The Works are what the Contract requires the Contractor to construct, install, and turn over to the Employer, as defined in the PCC. 
2. Interpretation

3. Language and Law
2.1 In interpreting these GCC, singular also means plural, male also means female or neuter, and the other way around. Headings have no significance. Words have their normal meaning under the language of the Contract unless specifically defined. The Project Manager shall provide instructions clarifying queries about these GCC.

2.2 If sectional completion is specified in the PCC, references in the GCC to the Works, the Completion Date, and the Intended Completion Date apply to any Section of the Works (other than references to the Completion Date and Intended Completion Date for the whole of the Works).

2.3 The documents forming the Contract shall be interpreted in the following order of priority:

(a) Contract Agreement,

(b) Letter of Acceptance,

(c) Letter of Bid,

(d) Particular Conditions of Contract,

(e) the List of Eligible Countries that was specified in Section 5 of the bidding document,

(f) General Conditions of Contract,

(g) Specifications,

(h) Drawings,

(i) Completed Activity Schedules or Bill of Quantities, and

(j) any other document listed in the PCC as forming part of the Contract.

3.1 The language of the Contract and the law governing the Contract are stated in the PCC.

3.2 Throughout the execution of the Contract, the Contractor shall comply with the import of goods and services prohibitions in the Employer's country when

(a) by an act of compliance with a decision of the United Nations Security Council taken under Chapter VII of the Charter of the United Nations, the Employer's Country prohibits any import of goods from, or any payments to, a particular country, person, or entity. Where the Borrower's country prohibits payments to a particular firm or for particular goods by such an act of compliance, that firm may be excluded. 


\section{Contract Agreement}

\section{Assignment}

\section{Care and Supply of Documents}

4.1 The Parties shall enter into a Contract Agreement within 28 days after the Contractor receives the Letter of Acceptance, unless the Particular Conditions establish otherwise. The Contract Agreement shall be based upon the attached Contract forms in Section 8. The costs of stamp duties and similar charges (if any) imposed by law in connection with entry into the Contract Agreement shall be borne by the Employer.

5.1 Neither Party shall assign the whole or any part of the Contract or any benefit or interest in or under the Contract. However, either Party

(a) may assign the whole or any part with the prior agreement of the other Party, at the sole discretion of such other Party; and

(b) may, as security in favor of a bank or financial institution, assign its right to any moneys due, or to become due, under the Contract.

6.1 The Specification and Drawings shall be in the custody and care of the Employer. Unless otherwise stated in the Contract, two copies of the Contract and of each subsequent Drawing shall be supplied to the Contractor, who may make or request further copies at the cost of the Contractor.

6.2 Each of the Contractor's Documents shall be in the custody and care of the Contractor, unless and until taken over by the Employer. Unless otherwise stated in the Contract, the Contractor shall supply to the Engineer six copies of each of the Contractor's Documents.

6.3 The Contractor shall keep, on the Site, a copy of the Contract, publications named in the Specification, the Contractor's Documents (if any), the Drawings and Variations and other communications given under the Contract. The Employer's Personnel shall have the right of access to all these documents at all reasonable times.

6.4 If a Party becomes aware of an error or defect in a document which was prepared for use in executing the Works, the Party shall promptly give notice to the other Party of such error or defect.

\section{Confidential Details}

7.1 The Contractor's and the Employer's Personnel shall disclose all such confidential and other information as may be reasonably required in order to verify the Contractor's compliance with the Contract and allow its proper implementation.

7.2 Each of them shall treat the details of the Contract as private and confidential, except to the extent necessary to carry out their respective obligations under the Contract or to comply with applicable Laws. Each of them shall not publish or disclose any particulars of the Works prepared by the other Party without the previous agreement of the other Party. However, the Contractor shall be permitted to disclose any publicly available information, or information otherwise required to establish his qualifications to compete for other projects. 
7.3 Notwithstanding the above, the Contractor may furnish to its Subcontractor(s) such documents, data, and other information it receives from the Employer to the extent required for the Subcontractor(s) to perform its work under the Contract, in which event the Contractor shall obtain from such Subcontractor(s) an undertaking of confidentiality similar to that imposed on the under this Clause.

\section{Compliance with Laws}

\section{Joint and Several Liability}

\section{Project Manager's Decisions}

\section{Delegation}

8.1 The Contractor shall, in performing the Contract, comply with applicable Laws.

8.2 Unless otherwise stated in the Particular Conditions,

(a) the Employer shall acquire and pay for all permits, approvals, and/or licenses from all local, state, or national government authorities or public service undertakings in the [Employer's Country or country where the Site is located] which (i) such authorities or undertakings require the Employer to obtain in the Employer's name, and (ii) are necessary for the execution of the Contract, including those required for the performance by both the Contractor and the Employer of their respective obligations under the Contract;

(b) the Contractor shall acquire and pay for all permits, approvals, and/or licenses from all local, state, or national government authorities or public service undertakings in the [Employer's Country or country where the Site is located] which such authorities or undertakings require the Contractor to obtain in its name and which are necessary for the performance of the Contract, including, without limitation, visas for the Contractor's and Subcontractor's personnel and entry permits for all imported Contractor's Equipment. The Contractor shall acquire all other permits, approvals, and/or licenses that are not the responsibility of the Employer under Subclause 8.2(a) hereof and that are necessary for the performance of the Contract. The Contractor shall indemnify and hold harmless the Employer from and against any and all liabilities, damages, claims, fines, penalties, and expenses of whatever nature arising or resulting from the violation of such laws by the Contractor or its personnel, including the Subcontractors and their personnel, but without prejudice to Subclause 8.1 hereof.

9.1 If the Contractor is a Joint Venture of two or more persons, all such persons shall be jointly and severally liable to the Employer for the fulfillment of the provisions of the Contract, and shall designate one of such persons to act as a leader with authority to bind the Joint Venture. The composition or the constitution of the Joint Venture shall not be altered without the prior consent of the Employer.

10.1 Except where otherwise specifically stated, the Project Manager shall decide contractual matters between the Employer and the Contractor in the role representing the Employer.

11.1 The Project Manager may delegate any of his duties and responsibilities to other people, except to the Adjudicator, after notifying the Contractor, and may cancel any delegation after notifying the Contractor. 
12. Communications

13. Subcontracting

14. Other

Contractors

\section{Personnel and Equipment}

12.1 Communications between parties that are referred to in the Conditions shall be effective only when in writing. A notice shall be effective only when it is delivered.

13.1 The Contractor may subcontract with the approval of the Project Manager, but may not assign the Contract without the approval of the Employer in writing. Subcontracting shall not alter the Contractor's obligations.

14.1 The Contractor shall cooperate and share the Site with other contractors, public authorities, utilities, and the Employer between the dates given in the Schedule of Other Contractors, as referred to in the PCC. The Contractor shall also provide facilities and services for them as described in the Schedule. The Employer may modify the Schedule of Other Contractors, and shall notify the Contractor of any such modification.

15.1 The Contractor shall employ the key personnel and use the equipment identified in its Bid, to carry out the functions stated in the Schedule or other personnel and equipment approved by the Project Manager. The Project Manager shall approve any proposed replacement of key personnel and equipment only if their relevant qualifications or characteristics are substantially equal to or better than those proposed in the Bid.

15.2 If the Project Manager asks the Contractor to remove a person who is a member of the Contractor's staff or work force, stating the reasons, the Contractor shall ensure that the person leaves the Site within 7 days and has no further connection with the work in the Contract.

15.3 Should any employee of the Contractor be determined, based on reasonable evidence, to have engaged in corrupt, fraudulent, collusive, coercive, or obstructive practices or other integrity violations during the execution of the Works, then that employee shall be removed in accordance with Clause 15.2 above.

16.1 The Employer carries the risks which this Contract states are Employer's risks, and the Contractor carries the risks which this Contract states are Contractor's risks. 
17. Employer's Risks

\section{Contractor's Risks}

17.1 From the Start Date until the Defects Liability Certificate has been issued, the following are Employer's risks:

(a) The risk of personal injury, death, or loss of or damage to property (excluding the Works, Plant, Materials, and Equipment), which are due to

(i) use or occupation of the Site by the Works or for the purpose of the Works, which is the unavoidable result of the Works, or

(ii) negligence, breach of statutory duty, or interference with any legal right by the Employer or by any person employed by or contracted to him except the Contractor.

(b) The risk of damage to the Works, Plant, Materials, and Equipment to the extent that it is due to a fault of the Employer or in the Employer's design, or due to war or radioactive contamination directly affecting the country where the Works are to be executed.

17.2 From the Completion Date until the Defects Liability Certificate has been issued, the risk of loss of or damage to the Works, Plant, and Materials is an Employer's risk except loss or damage due to

(a) a Defect which existed on the Completion Date,

(b) an event occurring before the Completion Date, which was not itself an Employer's risk, or

18.1 From the Starting Date until the Defects Liability Certificate has been issued, the risks of personal injury, death, and loss of or damage to property (including, without limitation, the Works, Plant, Materials, and Equipment), which are not Employer's risks, are Contractor's risks. 


\section{Insurance}

20. Site Investigation Reports

21. Contractor to Construct the Works

22. The Works to Be Completed by the Intended Completion Date
19.1 The Contractor shall provide, in the joint names of the Employer and the Contractor, insurance cover from the Start Date to the end of the Defects Liability Period, in the amounts and deductibles stated in the PCC for the following events, which are due to the Contractor's risks:

(a) loss of or damage to the Works, Plant, and Materials;

(b) loss of or damage to Equipment;

(c) loss of or damage to property (except the Works, Plant, Materials, and Equipment) in connection with the Contract; and

(d) personal injury or death.

19.2 Policies and certificates for insurance shall be delivered by the Contractor to the Project Manager for the Project Manager's approval before the Start Date. All such insurance shall provide for compensation to be payable in the types and proportions of currencies required to rectify the loss or damage incurred.

19.3 If the Contractor does not provide any of the policies and certificates required, the Employer may effect the insurance, which the Contractor should have provided and recover the premiums the Employer has paid from payments otherwise due to the Contractor or, if no payment is due, the payment of the premiums shall be a debt due.

19.4 Alterations to the terms of an insurance shall not be made without the approval of the Project Manager.

19.5 Both parties shall comply with any conditions of the insurance policies.

20.1 The Contractor, in preparing the Bid, shall rely on any Site Investigation Reports referred to in the PCC, supplemented by any information available to the Contractor.

21.1 The Contractor shall construct and install the Works in accordance with the Specifications and Drawings.

22.1 The Contractor may commence execution of the Works on the Start Date and shall carry out the Works in accordance with the Program submitted by the Contractor, as updated with the approval of the Project Manager, and complete them by the Intended Completion Date. 


\section{Designs by \\ Contractor and \\ Approval by the \\ Project Manager}

24. Safety

25. Discoveries

26. Possession
of the Site

27. Access to the Site
23.1 The Contractor shall carry out design to the extent specified in the PCC. The Contractor shall promptly submit to the Employer all designs prepared by him. Within 14 days of receipt, the Employer shall notify any comments. The Contractor shall not construct any element of the permanent work designed by him within 14 days after the design has been submitted to the Employer or where the design for that element has been rejected. Design that has been rejected shall be promptly amended and resubmitted. The Contractor shall resubmit all designs commented on, taking these comments into account as necessary.

23.2 The Contractor shall submit Specifications and Drawings showing the proposed Temporary Works to the Project Manager, who is to approve them if they comply with the Specifications and Drawings.

23.3 The Contractor shall be responsible for design of Temporary Works.

23.4 The Project Manager's approval shall not alter the Contractor's responsibility for design of the Temporary Works.

23.5 The Contractor shall obtain approval of third parties to the design of the Temporary Works, where required.

23.6 All Drawings prepared by the Contractor for the execution of the temporary or permanent Works, are subject to prior approval by the Project Manager before this use.

24.1 The Contractor shall be responsible for the safety of all activities on the Site.

25.1 Anything of historical or other interest or of significant value unexpectedly discovered on the Site shall be the property of the Employer. The Contractor shall notify the Project Manager of such discoveries and carry out the Project Manager's instructions for dealing with them.

26.1 The Employer shall give possession of all parts of the Site to the Contractor. If possession of a part is not given by the date stated in the PCC, the Employer shall be deemed to have delayed the start of the relevant activities, and this shall be a Compensation Event.

27.1 The Contractor shall allow the Project Manager and any person authorized by the Project Manager access to the Site and to any place where work in connection with the Contract is being carried out or is intended to be carried out. 


\section{Instructions, Inspections, and Audits}

\section{Appointment of the Adjudicator}

28.1 The Contractor shall carry out all instructions of the Project Manager, which comply with the applicable laws where the Site is located.

28.2 The Contractor shall keep, and shall make all reasonable efforts to cause its Subcontractors and subconsultants to keep accurate and systematic accounts and records in respect of the Works in such form and details as will clearly identify relevant time changes and costs.

28.3 The Contractor shall permit ADB or its representative to inspect the Contractor's site, assets, accounts, records, and other documents relating to the submission of bids and contract performance and to have them audited by auditors appointed by ADB. The Contractor shall maintain all documents and records related to the bid submission and the execution of the Contract for at least 5 years after completing the works contemplated in the relevant contracts or the period prescribed in applicable law, whichever is longer. The Contractor shall provide any documents necessary for the investigation of allegations of corrupt, fraudulent, collusive, coercive, or obstructive practices or other integrity violations and require its employees or agents with knowledge of the Contract to respond to questions from ADB.

28.4 ADB's right to inspect the Site and/or the Contractor's accounts and records relating to the performance of the Contract stated in Sub-Clause 28.3 and 74.2(e) shall survive termination and/ or expiration of this Contract.

29.1 The Adjudicator shall be appointed jointly by the Employer and the Contractor, at the time of the Employer's issuance of the Letter of Acceptance. If, in the Letter of Acceptance, the Employer does not agree on the appointment of the Adjudicator, the Employer will request the Appointing Authority designated in the PCC, to appoint the Adjudicator within 14 days of receipt of such request.

29.2 Should the Adjudicator resign or die, or should the Employer and the Contractor agree that the Adjudicator is not functioning in accordance with the provisions of the Contract, a new Adjudicator shall be jointly appointed by the Employer and the Contractor. In case of disagreement between the Employer and the Contractor, within 30 days, the Adjudicator shall be designated by the Appointing Authority at the request of either party, within 14 days of receipt of such request. 


\section{Procedure for Disputes}

\section{B. Staff and Labor}

31. Forced Labor

32. Child Labor

\section{Workers' Organizations}

30.1 If the Contractor believes that a decision taken by the Project Manager was either outside the authority given to the Project Manager by the Contract or that the decision was wrongly taken, the decision shall be referred to the Adjudicator within 14 days of the notification of the Project Manager's decision.

30.2 The Adjudicator shall give a decision in writing within 28 days of receipt of a notification of a dispute.

30.3 The Adjudicator shall be paid by the hour at the rate specified in the PCC, together with reimbursable expenses of the types specified in the PCC, and the cost shall be divided equally between the Employer and the Contractor, whatever decision is reached by the Adjudicator. Either party may refer a decision of the Adjudicator to an Arbitrator within 28 days of the Adjudicator's written decision. If neither party refers the dispute to arbitration within the above 28 days, the Adjudicator's decision shall be final and binding.

30.4 The arbitration shall be conducted in accordance with the arbitration procedures published by the institution named and in the place specified in the PCC.

31.1 The Contractor shall not employ forced labor, which consists of any work or service, not voluntarily performed, that is exacted from an individual under threat of force or penalty. This covers any kind of involuntary or compulsory labor, such as indentured labor, bonded labor, or similar laborcontracting arrangements.

32.1 The Contractor shall not employ children in a manner that is economically exploitative, or is likely to be hazardous, or to interfere with, the child's education, or to be harmful to the child's health or physical, mental, spiritual, moral, or social development. Where national laws have provisions for employment of minors, the Contractor shall follow those laws applicable to the Contractor. Children below the age of 18 years shall not be employed in dangerous work.

33.1 In countries where national law recognizes workers' rights to form and to join workers' organizations of their choosing without interference and to bargain collectively, the Contractor shall comply with national law. Where national law substantially restricts workers' organizations, the Contractor shall enable alternative means for the Contractor's Personnel to express their grievances and protect their rights regarding working conditions and terms of employment. In either case described above, and where national law is silent, the Contractor shall not discourage the Contractor's Personnel from forming or joining workers' organizations of their choosing or from bargaining collectively, and shall not discriminate or retaliate against the Contractor's Personnel who participate, or seek to participate, in such organizations and bargain collectively. The Contractor shall engage with such workers representatives. Worker organizations are expected to fairly represent the workers in the workforce. 
34. Nondiscrimination and Equal Opportunity

\section{Time Control}

\section{Program}

34.1 The Contractor shall not make employment decisions on the basis of personal characteristics unrelated to inherent job requirements. The Contractor shall base the employment relationship on the principle of equal opportunity and fair treatment, and shall not discriminate with respect to aspects of the employment relationship, including recruitment and hiring, compensation (including wages and benefits), working conditions and terms of employment, access to training, promotion, termination of employment or retirement, and discipline. In countries where national law provides for nondiscrimination in employment, the Contractor shall comply with national law. When national laws are silent on nondiscrimination in employment, the Contractor shall meet this Subclause's requirements. Special measures of protection or assistance to remedy past discrimination or selection for a particular job based on the inherent requirements of the job shall not be deemed discrimination.

35.1 Within the time stated in the PCC, after the date of the Letter of Acceptance, the Contractor shall submit to the Project Manager for approval a Program showing the general methods, arrangements, order, and timing for all the activities in the Works. In the case of a lump sum contract, the activities in the Program shall be consistent with those in the Activity Schedule.

35.2 An update of the Program shall be a program showing the actual progress achieved on each activity and the effect of the progress achieved on the timing of the remaining work, including any changes to the sequence of the activities.

35.3 The Contractor shall submit to the Project Manager for approval an updated Program at intervals no longer than the period stated in the PCC. If the Contractor does not submit an updated Program within this period, the Project Manager may withhold the amount stated in the PCC from the next payment certificate and continue to withhold this amount until the next payment after the date on which the overdue Program has been submitted. In the case of a lump sum contract, the Contractor shall provide an updated Activity Schedule within 14 days of being instructed to by the Project Manager.

35.4 The Project Manager's approval of the Program shall not alter the Contractor's obligations. The Contractor may revise the Program and submit it to the Project Manager again at any time. A revised Program shall show the effect of Variations and Compensation Events. 


\section{Extension of the Intended Completion Date}

37. Acceleration

38. Delays Ordered by the Project Manager

\section{Management Meetings}

\section{Early Warning}

36.1 The Project Manager shall extend the Intended Completion Date if a Compensation Event occurs or a Variation is issued which makes it impossible for Completion to be achieved by the Intended Completion Date without the Contractor taking steps to accelerate the remaining work, which would cause the Contractor to incur additional cost.

36.2 The Project Manager shall decide whether and by how much to extend the Intended Completion Date within 21 days of the Contractor asking the Project Manager for a decision upon the effect of a Compensation Event or Variation and submitting full supporting information. If the Contractor has failed to give early warning of a delay or has failed to cooperate in dealing with a delay, the delay by this failure shall not be considered in assessing the new Intended Completion Date.

37.1 When the Employer wants the Contractor to finish before the Intended Completion Date, the Project Manager shall obtain priced proposals for achieving the necessary acceleration from the Contractor. If the Employer accepts these proposals, the Intended Completion Date shall be adjusted accordingly and confirmed by both the Employer and the Contractor.

37.2 If the Contractor's priced proposals for an acceleration are accepted by the Employer, they are incorporated in the Contract Price and treated as a Variation.

38.1 The Project Manager may instruct the Contractor to delay the start or progress of any activity within the Works.

39.1 Either the Project Manager or the Contractor may require the other to attend a management meeting. The business of a management meeting shall be to review the plans for remaining work and to deal with matters raised in accordance with the early warning procedure.

39.2 The Project Manager shall record the business of management meetings and provide copies of the record to those attending the meeting and to the Employer. The responsibility of the parties for actions to be taken shall be decided by the Project Manager either at the management meeting or after the management meeting and stated in writing to all who attended the meeting.

40.1 The Contractor shall warn the Project Manager at the earliest opportunity of specific likely future events or circumstances that may adversely affect the quality of the work, increase the Contract Price, or delay the execution of the Works. The Project Manager may require the Contractor to provide an estimate of the expected effect of the future event or circumstance on the Contract Price and Completion Date. The estimate shall be provided by the Contractor as soon as reasonably possible.

40.2 The Contractor shall cooperate with the Project Manager in making and considering proposals for how the effect of such an event or circumstance can be avoided or reduced by anyone involved in the work and in carrying out any resulting instruction of the Project Manager. 


\section{Quality Control}

\section{Identifying Defects}

42. Tests

\section{Correction of Defects}

\section{Uncorrected Defects}

\section{E. Cost Control}

\section{Contract Price}

41.1 The Project Manager shall check the Contractor's work and notify the Contractor of any Defects that are found. Such checking shall not affect the Contractor's responsibilities. The Project Manager may instruct the Contractor to search for a Defect and to uncover and test any work that the Project Manager considers may have a Defect.

42.1 If the Project Manager instructs the Contractor to carry out a test not specified in the Specification to check whether any work has a Defect and the test shows that it does, the Contractor shall pay for the test and any samples. If there is no Defect, the test shall be a Compensation Event.

43.1 The Project Manager shall give notice to the Contractor of any Defects before the end of the Defects Liability Period, which begins at Completion, and is defined in the PCC. The Defects Liability Period shall be extended for as long as Defects remain to be corrected.

43.2 Every time notice of a Defect is given, the Contractor shall correct the notified Defect within the length of time specified by the Project Manager's notice.

44.1 If the Contractor has not corrected a Defect within the time specified in the Project Manager's notice, the Project Manager shall assess the cost of having the Defect corrected, and the Contractor shall pay this amount.

45.1 In the case of an admeasurement contract, the Bill of Quantities shall contain priced items for the Works to be performed by the Contractor. The Bill of Quantities is used to calculate the Contract Price. The Contractor will be paid for the quantity of the work accomplished at the rate in the Bill of Quantities for each item.

45.2 In the case of a lump sum contract, the Activity Schedule shall contain the priced activities for the Works to be performed by the Contractor. The Activity Schedule is used to monitor and control the performance of activities on which basis the Contractor will be paid. If payment for Materials on Site shall be made separately, the Contractor shall show delivery of Materials to the Site separately on the Activity Schedule. 


\section{Changes in the Contract Price}

\section{Variations} prevent a quotation being given and considered without delaying the work, no quotation shall be given and the Variation shall be treated as a Compensation Event.

47.5 The Contractor shall not be entitled to additional payment for costs that could have been avoided by giving early warning.

47.6 In the case of an admeasurement contract, if the work in the Variation corresponds to an item description in the Bill of Quantities and if, in the opinion of the Project Manager, the quantity of work above the limit stated in GCC 46.1 [Changes in the Contract Price] or the timing of its execution do not cause the cost per unit of quantity to change, the rate in the Bill of Quantities shall be used to calculate the value of the Variation. If the cost per unit of quantity changes, or if the nature or timing of the work in the Variation does not correspond with items in the Bill of Quantities, the quotation by the Contractor shall be in the form of new rates for the relevant items of work. 


\section{Cash Flow Forecasts}

\section{Payment Certificates}

50. Payments
48.1 When the Program, or, in the case of a lump sum contract, the Activity Schedule, is updated, the Contractor shall provide the Project Manager with an updated cash flow forecast. The cash flow forecast shall include different currencies, as defined in the Contract, converted as necessary using the Contract exchange rates.

49.1 The Contractor shall submit to the Project Manager monthly statements of the estimated value of the work executed less the cumulative amount certified previously.

49.2 The Project Manager shall check the Contractor's monthly statement and certify the amount to be paid to the Contractor.

49.3 The value of work executed shall be determined by the Project Manager.

49.4 The value of work executed shall comprise,

(a) in the case of an admeasurement contract, the value of the quantities of work in the Bill of Quantities that have been completed; or

(b) in the case of a lump sum contract, the value of work executed shall comprise the value of completed activities in the Activity Schedule.

49.5 The value of work executed shall include the valuation of Variations and Compensation Events.

49.6 The Project Manager may exclude any item certified in a previous certificate or reduce the proportion of any item previously certified in any certificate in the light of later information.

50.1 Payments shall be adjusted for deductions for advance payments and retention. The Employer shall pay the Contractor the amounts certified by the Project Manager within 28 days of the date of each certificate. If the Employer makes a late payment, the Contractor shall be paid interest on the late payment in the next payment. Interest shall be calculated from the date by which the payment should have been made up to the date when the late payment is made at the prevailing rate of interest for commercial borrowing for each of the currencies in which payments are made.

50.2 If an amount certified is increased in a later certificate or as a result of an award by the Adjudicator or an Arbitrator, the Contractor shall be paid interest upon the delayed payment as set out in this clause. Interest shall be calculated from the date upon which the increased amount would have been certified in the absence of dispute.

50.3 Unless otherwise stated, all payments and deductions shall be paid or charged in the proportions of currencies comprising the Contract Price.

50.4 Items of the Works for which no rate or price has been entered in shall not be paid for by the Employer and shall be deemed covered by other rates and prices in the Contract. 


\section{Compensation Events}

51.1 The following shall be Compensation Events:

(a) The Employer does not give access to a part of the Site by the Site Possession Date pursuant to GCC 26.1 [Possession of the Site].

(b) The Employer modifies the Schedule of Other Contractors in a way that affects the work of the Contractor under the Contract.

(c) The Project Manager orders a delay or does not issue Drawings, Specifications, or instructions required for execution of the Works on time.

(d) The Project Manager instructs the Contractor to uncover or to carry out additional tests upon work, which is then found to have no Defects.

(e) The Project Manager unreasonably does not approve a subcontract to be let.

(f) Ground conditions are substantially more adverse than could reasonably have been assumed before issuance of the Letter of Acceptance from the information issued to Bidders (including the Site Investigation Reports), from information available publicly and from a visual inspection of the Site.

(g) The Project Manager gives an instruction for dealing with an unforeseen condition, caused by the Employer, or additional work required for safety or other reasons.

(h) Other contractors, public authorities, utilities, or the Employer does not work within the dates and other constraints stated in the Contract, and they cause delay or extra cost to the Contractor.

(i) The advance payment is delayed.

(j) The effects on the Contractor of any of the Employer's Risks.

(k) The Project Manager unreasonably delays issuing a Certificate of Completion.

51.2 If a Compensation Event would cause additional cost or would prevent the work being completed before the Intended Completion Date, the Contract Price shall be increased and/or the Intended Completion Date shall be extended. The Project Manager shall decide whether and by how much the Contract Price shall be increased and whether and by how much the Intended Completion Date shall be extended. 
51.3 As soon as information demonstrating the effect of each Compensation Event upon the Contractor's forecast cost has been provided by the Contractor, it shall be assessed by the Project Manager, and the Contract Price shall be adjusted accordingly. If the Contractor's forecast is deemed unreasonable, the Project Manager shall adjust the Contract Price based on the Project Manager's own forecast. The Project Manager shall assume that the Contractor shall react competently and promptly to the event.

51.4 The Contractor shall not be entitled to compensation to the extent that the Employer's interests are adversely affected by the Contractor's not having given early warning or not having cooperated with the Project Manager.

52. Tax

\section{Currencies}

\section{Price Adjustment}

52.1 The Project Manager shall adjust the Contract Price if taxes, duties, and other levies are changed between the date 28 days before the submission of bids for the Contract and the date of the last Completion certificate. The adjustment shall be the change in the amount of tax payable by the Contractor, provided such changes are not already reflected in the Contract Price or are a result of GCC 54.1 [Price Adjustment].

53.1 Where payments are made in currencies other than the currency of the Employer's country specified in the PCC, the exchange rates used for calculating the amounts to be paid shall be the exchange rates stated in the Contractor's Bid.

54.1 Prices shall be adjusted for fluctuations in the cost of inputs only if provided for in the PCC. If so provided, the amounts certified in each payment certificate, before deducting for Advance Payment, shall be adjusted by applying the respective price adjustment factor to the payment amounts due in each currency. A separate formula of the type indicated below applies to each Contract currency:

$$
\mathbf{P}_{\mathrm{c}}=\mathbf{A}_{\mathrm{c}}+\mathbf{B}_{\mathrm{c}} \mathrm{Imc} / \mathrm{loc}
$$

where:

$\mathrm{P}_{c}$ is the adjustment factor for the portion of the Contract Price payable in a specific currency "c."

$A_{c}$ and $B_{c}$ are coefficients ${ }^{1}$ specified in the PCC, representing the nonadjustable and adjustable portions, respectively, of the Contract Price payable in that specific currency "c;" and

Imc is a consolidated index prevailing at the end of the month being invoiced and loc is the same consolidated index prevailing 28 days before Bid opening for inputs payable; both in the specific currency "c."

54.2 If the value of the index is changed after it has been used in a calculation, the calculation shall be corrected and an adjustment made in the next payment certificate. The index value shall be deemed to take account of all changes in cost due to fluctuations in costs.

The sum of the two coefficients $A c$ and $B c$ should be 1 (one) in the formula for each currency. Normally, both coefficients shall be the same in the formulas for all currencies, since coefficient $A$, for the nonadjustable portion of the payments, is a very approximate figure (usually $0.10 \sim 0.20$ ) to take account of fixed cost elements or other nonadjustable components. The sum of the adjustments for each currency is added to the Contract Price. 
55. Retention

\section{Liquidated Damages}

\section{Bonus}

\section{Advance Payment}

55.1 The Employer shall retain from each payment due to the Contractor the proportion stated in the PCC until Completion of the whole of the Works.

55.2 Upon the issue of a Certificate of Completion of the Works by the Project Manager, in accordance with GCC 69.1 [Completion], half the total amount retained shall be repaid to the Contractor and half when the Defects Liability Period has passed and the Project Manager has certified that all Defects notified by the Project Manager to the Contractor before the end of this period have been corrected. The Contractor may substitute retention money with an "on demand" bank guarantee.

56.1 The Contractor shall pay liquidated damages to the Employer at the rate per day stated in the PCC for each day that the Completion Date is later than the Intended Completion Date. The total amount of liquidated damages shall not exceed the amount defined in the PCC. The Employer may deduct liquidated damages from payments due to the Contractor. Payment of liquidated damages shall not affect the Contractor's liabilities.

56.2 If the Intended Completion Date is extended after liquidated damages have been paid, the Project Manager shall correct any overpayment of liquidated damages by the Contractor by adjusting the next payment certificate. The Contractor shall be paid interest on the overpayment, calculated from the date of payment to the date of repayment, at the rates specified in GCC 50.1 [Payments].

57.1 The Contractor shall be paid a Bonus calculated at the rate per calendar day stated in the PCC for each day (less any days for which the Contractor is paid for acceleration) that the Completion is earlier than the Intended Completion Date. The Project Manager shall certify that the Works are complete, although they may not be due to be complete.

58.1 The Employer shall make advance payment to the Contractor of the amounts stated in the PCC by the date stated in the PCC, against provision by the Contractor of an unconditional bank guarantee in a form and by a bank acceptable to the Employer in amounts and currencies equal to the advance payment. The guarantee shall remain effective until the advance payment has been repaid, but the amount of the guarantee shall be progressively reduced by the amounts repaid by the Contractor. Interest shall not be charged on the advance payment.

58.2 The Contractor is to use the advance payment only to pay for Equipment, Plant, Materials, and mobilization expenses required specifically for execution of the Contract. The Contractor shall demonstrate that advance payment has been used in this way by supplying copies of invoices or other documents to the Project Manager.

58.3 The advance payment shall be repaid by deducting proportionate amounts from payments otherwise due to the Contractor, following the schedule of completed percentages of the Works on a payment basis. No account shall be taken of the advance payment or its repayment in assessing valuations of work done, Variations, price adjustments, Compensation Events, Bonuses, or Liquidated Damages. 
59. Securities

60. Dayworks

61. Cost of Repairs

\section{F. Force Majeure}

62. Definition of Force Majeure
59.1 The Performance Security shall be provided to the Employer no later than the date specified in the Letter of Acceptance and shall be issued in an amount specified in the PCC, by a bank acceptable to the Employer, and denominated in the types and proportions of the currencies in which the Contract Price is payable. The Performance Security shall be valid until a date 28 days from the date of issue of the Certificate of Completion in the case of a bank guarantee.

60.1 If applicable, the Dayworks rates in the Contractor's Bid shall be used for small additional amounts of work only when the Project Manager has given written instructions in advance for additional work to be paid for in that way.

60.2 All work to be paid for as Dayworks shall be recorded by the Contractor on forms approved by the Project Manager. Each completed form shall be verified and signed by the Project Manager within 2 days of the work being done.

60.3 The Contractor shall be paid for Dayworks subject to obtaining signed Dayworks forms.

61.1 Loss or damage to the Works or Materials to be incorporated in the Works between the Start Date and the end of the Defects Correction periods shall be remedied by the Contractor at the Contractor's cost if the loss or damage arises from the Contractor's acts or omissions.

62.1 In this Clause, "Force Majeure" means an exceptional event or circumstance,

(a) which is beyond a Party's control;

(b) which such Party could not reasonably have provided against before entering into the Contract;

(c) which, having arisen, such Party could not reasonably have avoided or overcome; and

(d) which is not substantially attributable to the other Party. 
62.2 Force Majeure may include, but is not limited to, exceptional events or circumstances of the kind listed below, so long as conditions (a) to (d) above are satisfied:

(a) war, hostilities (whether war be declared or not), invasion, act of foreign enemies;

(b) rebellion, terrorism, sabotage by persons other than the Contractor's Personnel, revolution, insurrection, military or usurped power, or civil war;

(c) riot, commotion, disorder, strike, or lockout by persons other than the Contractor's Personnel;

(d) munitions of war, explosive materials, ionizing radiation or contamination by radioactivity, except as may be attributable to the Contractor's use of such munitions, explosives, radiation, or radioactivity; and

(e) natural catastrophes such as earthquake, hurricane, typhoon, or volcanic activity.

\section{Notice of Force Majeure}

\section{Duty to Minimize Delay}

63.1 If a Party is or will be prevented from performing its substantial obligations under the Contract by Force Majeure, then it shall give notice to the other Party of the event or circumstances constituting the Force Majeure and shall specify the obligations, the performance of which is or will be prevented. The notice shall be given within 14 days after the Party became aware, or should have become aware, of the relevant event or circumstance constituting Force Majeure.

63.2 The Party shall, having given notice, be excused from performance of its obligations for so long as such Force Majeure prevents it from performing them.

63.3 Notwithstanding any other provision of this Clause, Force Majeure shall not apply to obligations of either Party to make payments to the other Party under the Contract.

64.1 Each Party shall at all times use all reasonable endeavours to minimize any delay in the performance of the Contract as a result of Force Majeure.

64.2 A Party shall give notice to the other Party when it ceases to be affected by the Force Majeure. 


\section{Consequences of Force Majeure}

\section{Optional Termination, Payment, and Release}

65.1 If the Contractor is prevented from performing its substantial obligations under the Contract by Force Majeure of which notice has been given under GCC Subclause 63 [Notice of Force Majeure], and suffers delay and/or incurs Cost by reason of such Force Majeure, the Contractor shall be entitled subject to GCC Subclause 30.1 [Procedure for Disputes] to

(a) an extension of time for any such delay, if completion is or will be delayed, under GCC Subclause 36 [Extension of the Intended Completion Date]; and

(b) if the event or circumstance is of the kind described in subparagraphs (a) to (d) of GCC Subclause 62.2 [Definition of Force Majeure] and, in the case of subparagraphs (b) to (d), occurs in the Country, payment of any such Cost, including the costs of rectifying or replacing the Works and/or Goods damaged or destructed by Force Majeure, to the extent they are not indemnified through the insurance policy referred to in GCC Subclause 19 [Insurance].

65.2 After receiving this notice, the Project Manager shall proceed in accordance with GCC Subclause 10 [Project Manager's Decisions] to agree or determine these matters.

66.1 If any Subcontractor is entitled under any contract or agreement relating to the Works to relief from force majeure on terms additional to or broader than those specified in this Clause, such additional or broader Force Majeure events or circumstances shall not excuse the Contractor's nonperformance or entitle him to relief under this Clause.

67.1 If the execution of substantially all the Works in progress is prevented for a continuous period of 84 days by reason of Force Majeure of which notice has been given under GCC Subclause 63 [Notice of Force Majeure], or for multiple periods which total more than 140 days due to the same notified Force Majeure, then either Party may give to the other Party a notice of termination of the Contract. In this event, the termination shall take effect 7 days after the notice is given, and the Contractor shall proceed in accordance with GCC Subclause 73.5 [Termination]. 
67.2 Upon such termination, the Project Manager shall determine the value of the work done and issue a Payment Certificate, which shall include

(a) the amounts payable for any work carried out for which a price is stated in the Contract;

(b) the Cost of Plant and Materials ordered for the Works which have been delivered to the Contractor, or of which the Contractor is liable to accept delivery: this Plant and Materials shall become the property of (and be at the risk of) the Employer when paid for by the Employer, and the Contractor shall place the same at the Employer's disposal;

(c) other Costs or liabilities which in the circumstances were reasonably and necessarily incurred by the Contractor in the expectation of completing the Works;

(d) the Cost of removal of Temporary Works and Contractor's Equipment from the Site and the return of these items to the Contractor's works in his country (or to any other destination at no greater cost); and

(e) the Cost of repatriation of the Contractor's staff and labor employed wholly in connection with the Works at the date of termination.

\section{Release from} Performance
68.1 Notwithstanding any other provision of this Clause, if any event or circumstance outside the control of the Parties (including, but not limited to, Force Majeure) arises, which makes it impossible or unlawful for either or both Parties to fulfill its or their contractual obligations or which, under the law governing the Contract, entitles the Parties to be released from further performance of the Contract, then upon notice by either Party to the other Party of such event or circumstance,

(a) the Parties shall be discharged from further performance, without prejudice to the rights of either Party in respect of any previous breach of the Contract; and

(b) the sum payable by the Employer to the Contractor shall be the same as would have been payable under GCC Subclause 67 [Optional Termination, Payment and Release] if the Contract had been terminated under GCC Subclause 67.

\section{G. Finishing the Contract}

\section{Completion}

\section{Taking Over}

69.1 The Contractor shall request the Project Manager to issue a certificate of Completion of the Works, and the Project Manager shall do so upon deciding that the work is completed.

70.1 The Employer shall take over the Site and the Works within 7 days of the Project Manager's issuing a certificate of Completion. 
71. Final Account

72. Operating and Maintenance Manuals
71.1 The Contractor shall supply the Project Manager with a detailed account of the total amount that the Contractor considers payable under the Contract before the end of the Defects Liability Period. The Project Manager shall issue a Defects Liability Certificate and certify any final payment that is due to the Contractor within 56 days of receiving the Contractor's account if it is correct and complete. If it is not, the Project Manager shall issue within 56 days a schedule that states the scope of the corrections or additions that are necessary. If the Final Account is still unsatisfactory after it has been resubmitted, the Project Manager shall decide on the amount payable to the Contractor and issue a payment certificate.

72.1 If "as built" Drawings and/or operating and maintenance manuals are required, the Contractor shall supply them by the dates stated in the PCC.

72.2 If the Contractor does not supply the Drawings and/or manuals by the dates stated in the PCC pursuant to GCC 72.1, or they do not receive the Project Manager's approval, the Project Manager shall withhold the amount stated in the PCC from payments due to the Contractor. 
73. Termination

73.2 Fundamental breaches of Contract shall include, but shall not be limited to, the following:

(a) the Contractor stops work for 28 days when no stoppage of work is shown on the current Program and the stoppage has not been authorized by the Project Manager;

(b) the Project Manager instructs the Contractor to delay the progress of the Works, and the instruction is not withdrawn within 28 days;

(c) the Employer or the Contractor is made bankrupt or goes into liquidation other than for a reconstruction or amalgamation;

(d) a payment certified by the Project Manager is not paid by the Employer to the Contractor within 84 days of the date of the Project Manager's certificate;

(e) the Project Manager gives Notice that failure to correct a particular Defect is a fundamental breach of Contract and the Contractor fails to correct it within a reasonable period of time determined by the Project Manager;

(f) the Project Manager gives two consecutive Notices to update the Program and accelerate the works to ensure compliance with GCC Subclause 22.1 [The Works to Be Completed by the Intended Completion Date] and the Contractor fails to update the Program and demonstrate acceleration of the works within a reasonable period of time determined by the Project Manager;

(g) the Contractor does not maintain a Security, which is required;

(h) the Contractor has delayed the completion of the Works by the number of days for which the maximum amount of liquidated damages can be paid, as defined in the PCC; and

(i) if the Contractor, in the judgment of the Employer has engaged in integrity violations in competing for or in executing the Contract, pursuant to GCC 74.1 [Fraud and Corruption].

73.3 When either party to the Contract gives notice of a breach of Contract to the Project Manager for a cause other than those listed under GCC 73.2 above, the Project Manager shall decide whether the breach is fundamental or not.

73.4 Notwithstanding the above, the Employer may terminate the Contract for convenience.

73.5 If the Contract is terminated, the Contractor shall stop work immediately, make the Site safe and secure, and leave the Site as soon as reasonably possible. 


\section{Fraud and Corruption}

74.1 If the Employer determines, based on reasonable evidence, that the Contractor has engaged in corrupt, fraudulent, collusive or coercive practices, or other integrity violations, including the failure to disclose any required information which constitutes a fraudulent practice, in competing for or in executing the Contract, then the Employer may, after giving 14 days notice to the Contractor, terminate the Contract and expel him from the Site, and the provisions of Clause 73 [Termination] shall apply as if such termination had been made under Sub-Clause 73.2 (i).

74.2 ADB requires Borrowers (including beneficiaries of ADB-financed activity) and their personnel, as well as firms and individuals participating in an ADB-financed activity, including but not limited to, Bidders, Suppliers, and Contractors, agents, subcontractors, subconsultants, service providers, subsuppliers, manufacturers (including their respective officers, directors, employees and personnel) under ADB-financed contracts to observe the highest standard of ethics during the procurement and execution of such contracts in accordance with ADB's Anticorruption Policy (1998, as amended from time to time). In pursuance of this policy, ADB

(a) defines, for the purposes of this provision, the terms set forth below as follows:

(i) "corrupt practice" means the offering, giving, receiving, or soliciting, directly or indirectly, anything of value to influence improperly the actions of another party;

(ii) "fraudulent practice" means any act or omission, including a misrepresentation, that knowingly or recklessly misleads, or attempts to mislead, a party to obtain a financial or other benefit or to avoid an obligation;

(iii) "coercive practice" means impairing or harming, or threatening to impair or harm, directly or indirectly, any party or the property of the party to influence improperly the actions of a party;

(iv) "collusive practice" means an arrangement between two or more parties designed to achieve an improper purpose, including influencing improperly the actions of another party;

(v) "abuse" means theft, waste, or improper use of assets related to ADB-related activity, either committed intentionally or through reckless disregard;

(vi) "conflict of interest" means any situation in which a party has interests that could improperly influence that party's performance of official duties or responsibilities, contractual obligations, or compliance with applicable laws and regulations; and

(vii) "integrity violation" is any act, as defined under ADB's Integrity Principles and Guidelines (2015, as amended from time to time), which violates ADB's Anticorruption Policy, including (i) to (vi) above and the following: obstructive practice, violations of ADB sanctions, retaliation against whistleblowers or witnesses, and other violations of ADB's Anticorruption Policy, including failure to adhere to the highest ethical standard. 
(b) will reject a proposal for award if it determines that the Bidder recommended for award or any of its officers, directors, employees, personnel, subconsultants, subcontractors, service providers, suppliers or manufacturers has, directly or through an agent, engaged in corrupt, fraudulent, collusive, coercive, or obstructive practices or other integrity violations in competing for the Contract;

(c) will cancel the portion of the financing allocated to a contract if it determines at any time that representatives of the Borrower or of a beneficiary of ADB-financing engaged in corrupt, fraudulent, collusive, coercive, or obstructive practices or other integrity violations during the procurement or the execution of that contract, without the Borrower having taken timely and appropriate action satisfactory to $A D B$ to remedy the situation, including by failing to inform $A D B$ in a timely manner at the time they knew of the integrity violations;

(d) will impose remedial actions on a firm or an individual, at any time, in accordance with ADB's Anticorruption Policy and Integrity Principles and Guidelines, including declaring ineligible, either indefinitely or for a stated period of time, to participate ${ }^{1}$ in ADB-financed, -administered, or -supported activities or to benefit from an ADB-financed, -administered, or -supported contract, financially or otherwise, if it at any time determines that the firm or individual has, directly or through an agent, engaged in corrupt, fraudulent, collusive, coercive, or obstructive practices or other integrity violations; and

(e) will have the right to require that a provision be included in bidding documents and in contracts financed, administered, or supported by $A D B$, requiring Bidders, suppliers and contractors, consultants, manufacturers, service providers and other third parties engaged or involved in ADB-related activities, and their respective officers, directors, employees and personnel, to permit $A D B$ or its representative to inspect the site and their assets, accounts and records and other documents relating to the bid submission and contract performance and to have them audited by auditors appointed by ADB.

Whether as a Contractor, Subcontractor, Consultant, Manufacturer or Supplier, or Service Provider; or in any other capacity (different names are used depending on the particular Bidding Document). 
74.3 All Bidders, consultants, contractors, suppliers, manufacturers, service providers, and other third parties engaged or involved in ADB-related activities and their respective officers, directors, employees and personnel are obliged to cooperate fully in any investigation when requested by ADB to do so. As determined on a case by case basis by ADB, such cooperation includes, but is not limited to, the following:

(a) being available to be interviewed and replying fully and truthfully to all questions asked;

(b) providing ADB with any items requested that are within the party's control including, but not limited to, documents and other physical objects;

(c) upon written request by $A D B$, authorizing other related entities to release directly to ADB such information that is specifically and materially related, directly or indirectly, to the said entities or issues which are the subject of the investigation;

(d) cooperating with all reasonable requests to search or physically inspect their person and/or work areas, including files, electronic databases, and personal property used on ADB activities, or that utilizes ADB's Information and Communication Technology (ICT) resources or systems (including mobile phones, personal electronic devices, and electronic storage devices such as external disk drives);

(e) cooperating in any testing requested by $A D B$, including but not limited to, fingerprint identification, handwriting analysis, and physical examination and analysis; and

(f) preserving and protecting confidentiality of all information discussed with, and as required by, ADB.

74.4 All Bidders, consultants, contractors and suppliers shall require their officers, directors, employees, personnel, agents to ensure that, in its contracts with its subconsultants, Subcontractors and other third parties engaged or involved in ADB-related activities, such subconsultants, Subcontractors and other third parties similarly are obliged to cooperate fully in any investigation when requested by ADB to do so.

74.5 The Contractor undertakes that no fees, gratuities, rebates, gifts, commissions or other payments, other than those shown in the bid, have been given or received in connection with the procurement process or in the contract execution. ${ }^{2}$

2 The undertaking also applies during the period of performance of the contract. 


\section{Payment upon Termination}

76. Property

77. Release from
Performance

78. Suspension of ADB Loan or Credit
75.1 If the Contract is terminated because of a fundamental breach of Contract by the Contractor, the Project Manager shall issue a certificate for the value of the work done and Materials ordered less advance payments received up to the date of the issue of the certificate and less the percentage to apply to the value of the work not completed, as indicated in the PCC. Additional Liquidated Damages shall not apply. If the total amount due to the Employer exceeds any payment due to the Contractor, the difference shall be a debt payable to the Employer.

75.2 If the Contract is terminated for the Employer's convenience or because of a fundamental breach of Contract by the Employer, the Project Manager shall issue a certificate for the value of the work done, Materials ordered, the reasonable cost of removal of Equipment, repatriation of the Contractor's personnel employed solely on the Works, and the Contractor's costs of protecting and securing the Works, and less advance payments received up to the date of the certificate.

76.1 All Materials on the Site, Plant, Equipment, Temporary Works, and Works shall be deemed to be the property of the Employer if the Contract is terminated because of the Contractor's default.

77.1 If the Contract is frustrated by the outbreak of war or by any other event entirely outside the control of either the Employer or the Contractor, the Project Manager shall certify that the Contract has been frustrated. The Contractor shall make the Site safe and stop work as quickly as possible after receiving this certificate and shall be paid for all work carried out before receiving it and for any work carried out afterward to which a commitment was made.

78.1 In the event that ADB suspends the Loan or Credit to the Employer, from which part of the payments to the Contractor are being made,

(a) the Employer is obligated to notify the Contractor, with copy to the Project Manager, of such suspension within 7 days of having received ADB's suspension notice.

(b) if the Contractor has not received sums due it within the 28 days for payment provided for in GCC 50.1 [Payments], the Contractor may immediately issue a 14-day termination notice. 
79. Eligibility

79.1 The Contractor shall have the nationality of an eligible country as specified in Section 5 [Eligible Countries] of the bidding document. The Contractor shall be deemed to have the nationality of a country if the Contractor is a citizen or is constituted, incorporated, or registered, and operates in conformity with the provisions of the laws of that country. This criterion shall also apply to the determination of the nationality of proposed Subcontractors or Suppliers for any part of the Contract including related services.

79.2 The materials, equipment, and services to be supplied under the Contract shall have their origin in eligible source countries as specified in Section 5 [Eligible Countries] of the bidding document and all expenditures under the Contract will be limited to such materials, equipment, and services. At the Employer's request, the Contractor may be required to provide evidence of the origin of materials, equipment, and services.

79.3 For purposes of GCC 79.2, "origin” means the place where the materials and equipment are mined, grown, produced, or manufactured, and from which the services are provided. Materials and equipment are produced when, through manufacturing, processing, or substantial or major assembling of components, a commercially recognized product results that differs substantially in its basic characteristics or in purpose or utility from its components. 


\section{Section 8: Particular Conditions of Contract}

This Particular Conditions of Contract (PCC) complements Section 7 (General Conditions of Contract), specifying data and contractual requirements linked to the special circumstances of the country, Employer, Project Manager, sector, overall project, and the Works. The PCC complements the GCC in the same way the Bid Data Sheet complements the Instructions to Bidders.

The PCC has more detailed terms and conditions, which the Employer will apply in administering the specific contract. These provisions do not constitute a complete standard set of provisions. Employers should prepare country- or project-specific provisions for the PCC, and these should be developed into standard provisions.

Whoever drafts the PCC should be thoroughly familiar with the provisions of the GCC and with any specific requirements of the Contract. Legal advice is recommended when amending provisions or drafting new ones. Note that clause numbers in the PCC correspond to those in the GCC, but the PCC provisions take precedence over those in the GCC. 


\section{Particular Conditions of Contract}

Except where otherwise indicated, all PCC forms should be filled out by the Employer prior to issuance of the Bidding Documents. Schedules and reports to be provided by the Employer should be annexed.

A. General

\begin{tabular}{|c|c|}
\hline GCC 1.1(d) & The financing institution is Asian Development Bank \\
\hline GCC 1.1(r) & $\begin{array}{l}\text { The Employer is [insert name, address, and name of authorized representative]. } \\
\text { [The Employer should be the Executing Agency/Implementing Agency named in the Financing Agreement or the } \\
\text { entity authorized to carry out the procurement activities under the Project Administration Manual] }\end{array}$ \\
\hline GCC 1.1(w) & $\begin{array}{l}\text { The Intended Completion Date for the whole of the Works shall be [insert date]. } \\
\text { [If different dates are specified for completion of the Works by section ("sectional completion" or milestones), these } \\
\text { dates should be listed here] }\end{array}$ \\
\hline GCC 1.1(cc) & The Project Manager is [insert name, address, and/or name of authorized representative]. \\
\hline GCC 1.1(ff) & The Site is located at [insert address of Site] and is defined in drawings no. [insert numbers] \\
\hline GCC 1.1(ii) & The Start Date shall be [insert date]. \\
\hline $\mathrm{GCC} 1.1(\mathrm{~mm})$ & The Works consist of [insert brief summary, including relationship to other contracts under the Project]. \\
\hline GCC 2.2 & Sectional Completions are: [insert nature and dates, if appropriate] \\
\hline GCC 2.3(j) & The following documents also form part of the Contract: [list documents] \\
\hline GCC 3.1 & $\begin{array}{l}\text { The language of the contract is [insert name of the language. The language shall be that of the bid]. } \\
\text { The law that applies to the Contract is the law of [insert name of country]. }\end{array}$ \\
\hline GCC 11.1 & The Project Manager [insert "may" or "may not"] delegate any of his duties and responsibilities. \\
\hline GCC 14.1 & Schedule of other contractors: [insert Schedule of Other Contractors, if appropriate] \\
\hline GCC 19.1 & $\begin{array}{l}\text { The minimum insurance amounts and deductibles shall be } \\
\text { (a) for loss or damage to the Works, Plant and Materials: [insert amounts]. } \\
\text { (b) for loss or damage to Equipment: [insert amounts]. } \\
\text { (c) for loss or damage to property (except the Works, Plant, Materials, and Equipment) } \\
\text { in connection with Contract [insert amounts]. } \\
\text { (d) for personal injury or death: } \\
\text { (i) of the Contractor's employees: [insert amount]. } \\
\text { (ii) of other people: [insert amount]. }\end{array}$ \\
\hline GCC 20.1 & Site Investigation Reports are: [list site investigation reports] \\
\hline
\end{tabular}




\begin{tabular}{|c|c|}
\hline GCC 23.1 & $\begin{array}{l}\text { The following shall be designed by the Contractor: } \\
\text { [list if appropriate] }\end{array}$ \\
\hline GCC 26.1 & The Site Possession Date(s) shall be: [insert location(s) and date(s)] \\
\hline GCC 29.1 & $\begin{array}{l}\text { Appointing Authority for the Adjudicator: [insert name of authority] } \\
\text { [The appointing authority should be a person or an entity that is independent of the employer/project executing } \\
\text { agency/project implementing agency.] }\end{array}$ \\
\hline GCC 30.3 & $\begin{array}{l}\text { The Adjudicator shall be paid by the hour at the rate of: [insert rate]. } \\
\text { The reimbursable expenses are: [insert reimbursable expenses] }\end{array}$ \\
\hline GCC 30.4 & $\begin{array}{l}\text { Institution whose arbitration procedures shall be used: [select from below] } \\
\text { (a) Contracts with foreign contractors: } \\
\text { International arbitration shall be conducted in accordance with the rules of [insert here } \\
\text { the preferred international arbitration rules]. If no rules have been specified, then Rules of the } \\
\text { Singapore International Arbitration Centre (SIAC) shall apply. } \\
\text { Arbitration shall be administered by [insert institution here]. If no institution has been } \\
\text { specified, then SIAC shall be the institution to administer the arbitration. } \\
\text { The place of arbitration shall be: the place of the institution administering the arbitration. } \\
\text { (b) Contracts with domestic contractors: } \\
\text { Arbitration shall be conducted in accordance with the laws of the Employer's country. }\end{array}$ \\
\hline GCC 34.2 & $\begin{array}{l}\text { The following sentence shall apply: } \\
\text { Respectful Work Environment } \\
\text { The Contractor shall ensure that its employees and Subcontractors observe the highest ethical } \\
\text { standards and refrain from any form of bullying, discrimination, misconduct and harassment, } \\
\text { including sexual harassment and shall, at all times, behave in a manner that creates an environment } \\
\text { free of unethical behavior, bullying, misconduct and harassment, including sexual harassment. } \\
\text { The Contractor shall take appropriate action against any employees or Subcontractors, including } \\
\text { suspension or termination of employment or sub-contract, if any form of unethical or inappropriate } \\
\text { behavior is identified. } \\
\text { The Contractor shall conduct training programs for its employees and Subcontractors to raise } \\
\text { awareness on and prevent any form of bullying, discrimination, misconduct and harassment } \\
\text { including sexual harassment, and to promote a respectful work environment. The Contractor shall } \\
\text { keep an up to date record of its employees and Subcontractors who have attended and completed } \\
\text { such training programs and provide such records to the Employer or the Engineer at their first } \\
\text { written request. }\end{array}$ \\
\hline
\end{tabular}




\section{B. Time Control}

\begin{tabular}{|l|l|}
\hline GCC 35.1 & $\begin{array}{l}\text { The Contractor shall submit for approval a Program for the Works within [insert number] days } \\
\text { from the date of the Letter of Acceptance. }\end{array}$ \\
\hline GCC 35.3 & $\begin{array}{l}\text { The period between Program updates is [insert number] days. } \\
\text { The amount to be withheld for late submission of an updated Program is [insert amount]. }\end{array}$
\end{tabular}

\section{Quality Control}

\begin{tabular}{l|l} 
GCC 43.1 & The Defects Liability Period is: [insert number] days. \\
{$[$ The defects liability period is usually limited to 12 months, but could be less in very simple cases $]$}
\end{tabular}

\section{Cost Control}

\begin{tabular}{|c|c|}
\hline GCC 53.1 & The currency of the Employer's country is: [insert name of currency of the Employer's country]. \\
\hline GCC 54.1 & $\begin{array}{l}\text { The Contract [insert "is" or "is not"] subject to price adjustment in accordance with } \\
\text { GCC Clause 54, and the following information regarding coefficients [specify "does" or "does not"] } \\
\text { apply. } \\
\text { [Price adjustment is mandatory for contracts that provide long duration for time of completion (generally exceeds } \\
18 \text { months)] } \\
\text { The coefficients and indexes for adjustment of prices in local and foreign currencies shall be } \\
\text { as specified in the Table(s) of Adjustment Data submitted together with the Letter of Bid. }\end{array}$ \\
\hline GCC 55.1 & $\begin{array}{l}\text { The proportion of payments retained is: [insert percentage] } \\
\text { [The retention amount is usually close to 5\% and in no case exceeds 10\%.] }\end{array}$ \\
\hline GCC 56.1 & $\begin{array}{l}\text { The liquidated damages for the whole of the Works are [insert percentage of the final Contract Price] } \\
\text { per day. The maximum amount of liquidated damages for the whole of the Works is } \\
\text { [insert percentage] of the final Contract Price. } \\
\text { [Usually liquidated damages are set between } 0.05 \% \text { and } 0.10 \% \text { per day, and the total amount is not to exceed } \\
\text { between } 5 \% \text { and } 10 \% \text { of the contract price. If sectional completion and damages per section have been agreed, the } \\
\text { latter should be specified here.] }\end{array}$ \\
\hline GCC 57.1 & $\begin{array}{l}\text { The Bonus for the whole of the Works is [insert percentage of final Contract Price] per day. } \\
\text { The maximum amount of Bonus for the whole of the Works is [insert percentage] of the } \\
\text { final Contract Price. } \\
\text { [If early completion would provide benefits to the Employer, this clause should remain; otherwise state "not } \\
\text { applicable". The bonus is usually numerically equal to the liquidated damages.] }\end{array}$ \\
\hline
\end{tabular}




\begin{tabular}{|l|l|}
\hline GCC 58.1 & $\begin{array}{l}\text { The Advance Payments shall be: [insert amount(s)] and shall be paid to the Contractor no later } \\
\text { than [insert date(s)]. }\end{array}$ \\
\hline GCC 58.3 & $\begin{array}{l}\text { Repayment of the Advance Payments shall be: [insert percentage] from each payment } \\
\text { certificate. [An amount of 10\%-15\% of each payment certificate may be appropriate for admeasurement } \\
\text { contracts. Higher percentage shall be considered for lump sum contracts with activity schedules taking into } \\
\text { account the estimated number of payment certificates.] }\end{array}$ \\
\hline GCC 59.1 & $\begin{array}{l}\text { The Performance Security amount is [insert amount(s) denominated in the types and proportions of the } \\
\text { currencies in which the contract price is payable, or in a freely convertible currency acceptable to the Employer]. } \\
{\left[\begin{array}{l}\text { An amount of 5\% to 10\% of the contract price is commonly specified for performance bank guarantees.] } \\
{[\text { When additional performance security is required due to a seriously unbalanced or front-loaded or abnormally }} \\
\text { low bid in accordance with ITB } 36 \text { and 37, the Employer should specify the percentage of the performance } \\
\text { security and the terms for its release.] }\end{array}\right.}\end{array}$ \\
\hline
\end{tabular}

\section{E. Finishing the Contract}

\begin{tabular}{|l|l|}
\hline GCC 72.1 & $\begin{array}{l}\text { The date by which operating and maintenance manuals are required is [insert date]. } \\
\text { The date by which "as built" drawings are required is [insert date]. }\end{array}$ \\
\hline GCC 72.2 & $\begin{array}{l}\text { The amount to be withheld for failing to produce "as built" drawings and/or operating and } \\
\text { maintenance manuals by the date required in GCC 72.1 is [insert amount in local currency]. }\end{array}$ \\
\hline GCC 73.2(h) & The maximum number of days is: [insert number; consistent with Clause 56.1 on liquidated damages]. \\
\hline GCC 75.1 & $\begin{array}{l}\text { The percentage to apply to the value of the work not completed, representing the Employer's } \\
\text { additional cost for completing the Works, is [insert percentage]. }\end{array}$ \\
\hline
\end{tabular}




\section{Section 9: Contract Forms}

This section contains forms which, once completed, will form part of the Contract. The forms for Performance Security and Advance Payment Security, when required, shall only be completed by the successful Bidder after contract award.

\section{Table of Forms}

Notice of Intention for Award of Contract ...............................................................................................................161

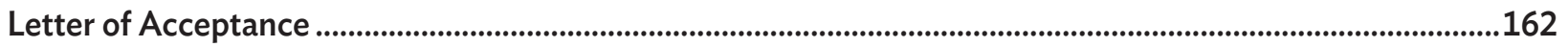

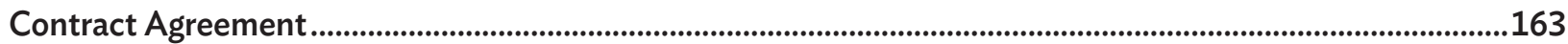

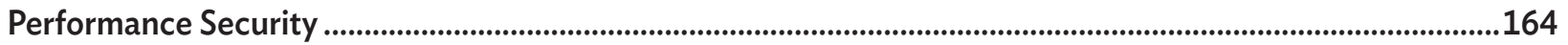

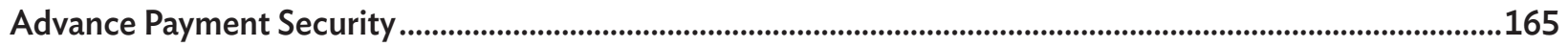




\section{Notice of Intention for Award of Contract}

[on letterhead paper of the Employer]

[date of notification]

To: $\quad$ [name of the Bidder]

Attention: [insert name of the Bidder's authorized representative]

Address: [insert address of the Bidder's authorized representative]

Telephone/Fax numbers: [insert telephone/fax numbers of the Bidder's authorized representative]

E-mail Address: [insert e-mail address of the Bidder's authorized representative]

This is to notify you of our intention to award the contract [insert name of the contract and identification number, as given in the Bid Data Sheet]. You have [insert number of days as specified in ITB 40.1 of the BDS] days, from the date of this notification to (i) request for a debriefing in relation to the evaluation of your Bid, and/or (ii) submit a bidding-related complaint in relation to the intention for award of contract, in accordance with the procedures specified in ITB 45.1.

The summary of the evaluation are as follows:

1. List of Bidders [insert names of all Bidders that submitted a bid together with the corresponding bid price at opening and evaluated bid price (if applicable)]

\begin{tabular}{|l|l|l|}
\hline Name of Bidder & Bid Price as Read Out at Opening & Evaluated Bid Price \\
\hline & & \\
\hline & & \\
\hline & & \\
\hline
\end{tabular}

\section{Reason/s Why Your Bid Was Unsuccessful}

[provide reasons separately to each unsuccessful Bidder why its bid was unsuccessful]

\section{The Successful Bidder}

\begin{tabular}{|l|l|}
\hline Name of Bidder: & \\
\hline Address: & \\
\hline Accepted Contract Amount: & \\
\hline Duration of Contract: & \\
\hline Scope of the Contract Awarded: & \\
\hline Amount Performance Security Required: & \\
\hline
\end{tabular}

Authorized Signature:

Name and Title of Signatory:

Name of Agency:

\section{NOTE}

The Employer should send this notification simultaneously to each Bidder that submitted a bid. Notice of Intention for Award of Contract shall only be included if standstill provision is applicable in accordance with ITB 40.1. 


\section{Letter of Acceptance}

[on letterhead paper of the Employer]

To: [name and address of the contractor]

Subject: Contract No. [please specify]

This is to notify you that your Bid dated [date] for execution of the [name of the contract and identification number, as given in the Bid Data Sheet ] for the Accepted Contract Amount in the equivalent of [amount in words and figures and name of currency] as corrected and modified in accordance with the Instructions to Bidders, is hereby accepted by our Agency.

You are requested to furnish the Performance Security within 28 days in accordance with the Conditions of Contract and any additional security required as a result of the evaluation of your bid, using for that purpose the Performance Security Form included in Section 9 (Contract Forms) of the Bidding Document.

[Choose one of the following statements:]

We accept that [insert the name of adjudicator proposed by the bidder] be appointed as the Adjudicator.

[or]

We do not accept that [insert the name of the adjudicator proposed by the bidder] be appointed as the Adjudicator, and by sending a copy of this Letter of Acceptance to [insert name of the appointing authority], the Appointing Authority, we are hereby requesting such Authority to appoint the Adjudicator in accordance with GCC 29.1.

Authorized Signature:

Name and Title of Signatory:

Name of Agency:

Attachment: Contract Agreement 


\section{Contract Agreement}

THIS AGREEMENT made the [date] day of [month], [year], between [name of the Employer] (hereinafter "the Employer"), of the one part, and [name of the contractor] (hereinafter "the Contractor"), of the other part:

WHEREAS the Employer desires that the Works known as [name of the contract] should be executed by the Contractor, and has accepted a Bid by the Contractor for the execution and completion of these Works and the remedying of any defects therein,

The Employer and the Contractor agree as follows:

1. In this Agreement, words and expressions shall have the same meanings as are respectively assigned to them in the Contract documents referred to.

2. The following documents shall be deemed to form and be read and construed as part of this Agreement. This Agreement shall be interpreted in the following order of priority and shall prevail over all other Contract documents.

(a) Letter of Acceptance,

(b) Letter of Bid,

(c) Addenda Nos. [insert addenda number if any $]^{1}$

(d) Particular Conditions of Contract,

(e) List of Eligible Countries that was specified in Section 5 of the bidding document,

(f) General Conditions of Contract,

(g) Specifications,

(h) Drawings,

(i) Completed Activity Schedules or Bill of Quantities, and

(j) any other documents shall be added here. ${ }^{2}$

3. In consideration of the payments to be made by the Employer to the Contractor as indicated in this Agreement, the Contractor hereby covenants with the Employer to execute the Works and to remedy defects therein in conformity in all respects with the provisions of the Contract.

4. The Employer hereby covenants to pay the Contractor in consideration of the execution and completion of the Works and the remedying of defects therein, the Contract Price or such other sum as may become payable under the provisions of the Contract at the times and in the manner prescribed by the Contract.

IN WITNESS whereof the parties hereto have caused this Agreement to be executed in accordance with the laws of [name of the borrowing country] on the day, month, and year indicated above.

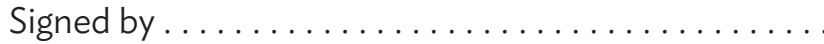

for and on behalf of the Employer

in the presence of

Witness, Name, Signature, Address, Date
Signed by................

for and on behalf the Contractor

in the presence of

Witness, Name, Signature, Address, Date

1 Information contained in the addenda and or addendum should preferably be included in the contract documents to avoid potential ambiguities during contract implementation. If however, unavoidable priority should be decided depending on the nature of information provided in the addenda/addendum.

2 Tables of Adjustment Data may be added if the contract provides for price adjustment (see GCC 54.1). 


\section{Performance Security}

[Bank's name and address of issuing branch or office $]^{1}$

Beneficiary:

[Name and address of the Employer]

Date:

Performance Guarantee No.:

We have been informed that [name of the contractor] (hereinafter called "the Contractor") has entered into Contract No. [reference number of the contract] dated [date] with you, for the execution of [name of contract and brief description of works] (hereinafter called "the Contract").

Furthermore, we understand that, according to the conditions of the Contract, a performance guarantee is required.

At the request of the Contractor, we [name of the bank] hereby irrevocably undertake to pay you any sum or sums not exceeding in total an amount of [name of the currency and amount in words] ${ }^{2}$ [amount in figures] such sum being payable in the types and proportions of currencies in which the Contract Price is payable, upon receipt by us of your first demand in writing accompanied by a written statement stating that the Contractor is in breach of its obligation(s) under the Contract, without your needing to prove or to show grounds for your demand or the sum specified therein.

This guarantee shall expire, no later than the [date] day of [month], [year], ${ }^{3}$ and any demand for payment under it must be received by us at this office on or before that date.

This guarantee is subject to the Uniform Rules for Demand Guarantees (URDG) 2010 Revisions, ICC Publication No. 758, except that the supporting statement under Article 15(a) is hereby excluded. ${ }^{4}$

[Signature(s) and seal of bank (where appropriate)]

\section{Note to Bidder}

If the bank issuing performance security is located outside the Employer's country, it shall be counter-guaranteed or encashable by a bank in the Employer's country.

All italicized text is for guidance on how to prepare this demand guarantee and shall be deleted from the final document.

The guarantor shall insert an amount representing the percentage of the contract price specified in the contract and denominated either in the currency(ies) of the contract or in any freely convertible currency acceptable to the employer. If the bank issuing the performance security is located outside the country of the Employer, it shall have a correspondent financial institution located in the country of the Employer.

3 Insert the date 28 days after the expected defect liability period. The Employer should note that in the event of an extension of the time for completion of the contract, the employer would need to request an extension of this guarantee from the guarantor. Such request must be in writing and must be made prior to the expiration date established in the guarantee. In preparing this guarantee, the employer might consider adding the following text to the form, at the end of the penultimate paragraph: "The Guarantor agrees to a one-time extension of this guarantee for a period not to exceed [6 months] [ 1 year], in response to the Employer's written request for such extension, such request to be presented to the Guarantor before the expiry of the guarantee."

$4 \quad$ Or the employer may use "Uniform Rules for Demand Guarantees (URDG), ICC Publication No. 458, except that subparagraph (ii) of Sub-article 20(a) is hereby excluded" as appropriate. 


\section{Advance Payment Security}

[Bank's name and address of issuing branch or office $]^{1}$

Beneficiary:

[Name and address of the employer]

Date:

Advance Payment Guarantee No.:

We have been informed that [name of the contractor] (hereinafter called "the Contractor") has entered into Contract No. [reference number of the contract] dated [date] with you, for the execution of [name of contract and brief description of works] (hereinafter called "the Contract").

Furthermore, we understand that, according to the Conditions of the Contract, an advance payment in the sum [name of the currency and amount in words] ${ }^{2}$ [amount in figures] is to be made against an advance payment guarantee.

At the request of the Contractor, we [name of the bank hereby irrevocably undertake to pay you any sum or sums not exceeding in total an amount of [name of the currency and amount in words] ${ }^{3}$ [amount in figures] upon receipt by us of your first demand in writing accompanied by a written statement stating that the Contractor is in breach of its obligation under the Contract because the Contractor:

(a) used the advance payment for purposes other than the costs of mobilization and cash flow support in respect of the Works; or

(b) has failed to repay the advance payment when it has become due and payable in accordance with the conditions of the Contract, specifying the amount payable by the Contractor.

It is a condition for any claim and payment under this guarantee to be made that the advance payment referred to above must have been received by the Contractor on its account number [contractor's account number] at [name and address of the bank].

The maximum amount of this guarantee shall be progressively reduced by the amount of the advance payment repaid by the Contractor as indicated in copies of interim statements or payment certificates which shall be presented to us. This guarantee shall expire, at the latest, upon our receipt of a copy of the interim payment certificate indicating that eighty percent (80\%) of the Contract Price has been certified for payment, or on the [date] day of [month], [year], ${ }^{4}$ whichever is earlier. Consequently, any demand for payment under this guarantee must be received by us at this office on or before that date.

This guarantee is subject to the Uniform Rules for Demand Guarantees (URDG) 2010 Revisions, ICC Publication No. 758, except that the supporting statement under Article 15(a) is hereby excluded. ${ }^{5}$

Signature(s) and seal of bank (where appropriate)

\section{Note to Bidder}

If the bank issuing advance payment security is located outside the Employer's country, it shall be counter-guaranteed or encashable by a bank in the Employer's country.

All italicized text is for guidance on how to prepare this demand guarantee and shall be deleted from the final document.

The guarantor shall insert an amount representing the amount of the advance payment denominated either in the currency(ies) of the advance payment as specified in the Contract, or in any freely convertible currency acceptable to the employer.

Footnote 2.

Insert the expected expiration date of the time for completion. The employer should note that in the event of an extension of the time for completion of the contract, the employer would need to request an extension of this guarantee from the guarantor. Such request must be in writing and must be made prior to the expiration date established in the guarantee. In preparing this guarantee, the employer might consider adding the following text to the form, at the end of the penultimate paragraph: "The Guarantor agrees to a one-time extension of this guarantee for a period not to exceed [6 months] [1 year], in response to the Employer's written request for such extension, such request to be presented to the Guarantor before the expiry of the guarantee."

5 Or the employer may use "Uniform Rules for Demand Guarantees (URDG), ICC Publication No. 458, except that subparagraph (ii) of Sub-article 20(a) is hereby excluded" as appropriate. 


\section{User Guide for Procurement of Works: Small Contracts Standard Bidding Document}

This User's Guide is intended to provide guidance to borrowers on how to prepare a bidding document for unit price or lump sum types of small works contracts that incorporate postqualification, and how to evaluate bids and award contracts based on the Asian Development Bank's Standard Bidding Document for the Procurement of Works, Small Contracts. It is applicable to projects governed by the Procurement Regulations for ADB Borrowers: Goods, Works, Nonconsulting and Consulting Services (2017, as amended from time to time).

\section{About the Asian Development Bank}

ADB is committed to achieving a prosperous, inclusive, resilient, and sustainable Asia and the Pacific, while sustaining its efforts to eradicate extreme poverty. Established in 1966, it is owned by 68 members -49 from the region. Its main instruments for helping its developing member countries are policy dialogue, loans, equity investments, guarantees, grants, and technical assistance. 